\title{
Total Synthesis of Formamicin
}

Timothy B. Durham, Nicolas Blanchard, Brad M. Savall, Noel A. Powell, and William R. Roush

Department of Chemistry, University of Michigan

930 N. University, Ann Arbor, MI 48109

roush@umich.edu

Supporting Information

Part I

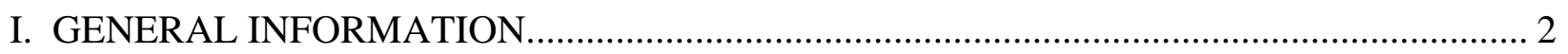

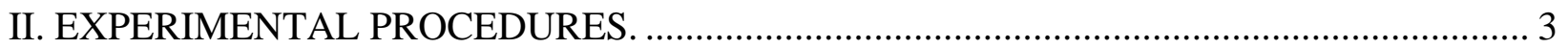



B. Second Generation Synthesis of Fragment 7 ……….................................................... 24

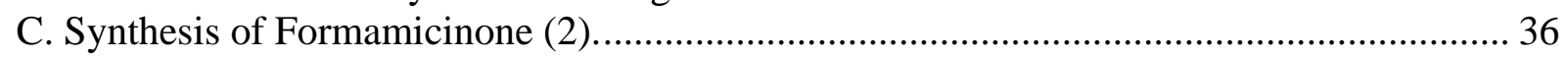

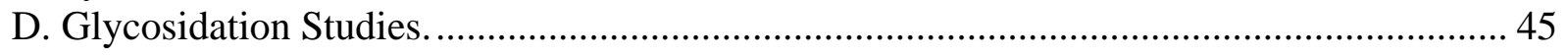

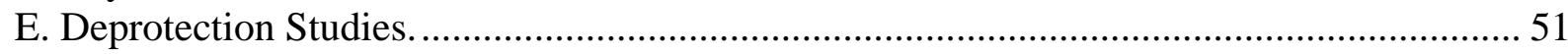

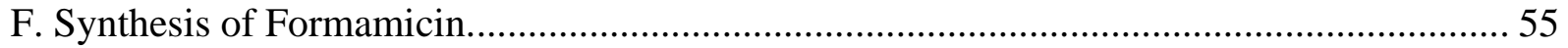

Analytical Data for Synthetic Formamicin ................................................................ 58

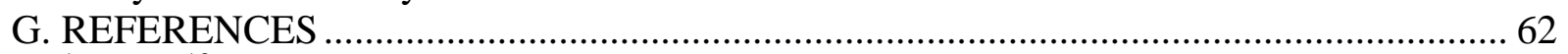

H. ${ }^{1} \mathrm{H}$ and ${ }^{13} \mathrm{C}$ NMR Spectra for Synthetic and Natural Formamicin.......................66

\section{Part II}

SELECTED ${ }^{1} \mathrm{H}$ NMR SPECTRA FOR COMPOUNDS 2 TO 96. 


\section{GENERAL INFORMATION.}

General Methods: All reaction solvents were purified before use. Tetrahydrofuran, dichloromethane, diethyl ether, and toluene were purified by passage through a solvent column composed of activated A-1 alumina. ${ }^{1}$ Unless otherwise indicated, all commercial reagents were used as received without further purification.

Physical Properties and Spectroscopic Measurements: Proton nuclear magnetic resonance $\left({ }^{1} \mathrm{H}\right.$ NMR) spectra and carbon-13 $\left({ }^{13} \mathrm{C}\right)$ NMR spectra were recorded on a Varian VXR-400 spectrometer at $400 \mathrm{MHz}$ and $100 \mathrm{MHz}$ respectively, or on a Varian Inova-500 spectrometer at $500 \mathrm{MHz}$ and $125 \mathrm{MHz}$ respectively. The proton signal of residual, non-deuterated solvent ( $\delta$ $7.26 \mathrm{ppm}$ for $\mathrm{CHCl}_{3} ; \delta 7.16 \mathrm{ppm}$ for $\mathrm{C}_{6} \mathrm{D}_{5} \mathrm{H}$ ) or tetramethylsilane ( $\delta 0 \mathrm{ppm}, \mathrm{CDCl}_{3}$ ) was used as an internal reference for ${ }^{1} \mathrm{H}$ spectra. For ${ }^{13} \mathrm{C}$ spectra, chemical shifts are reported relative to the $\delta$ $77.23 \mathrm{ppm}$ resonance of $\mathrm{CDCl}_{3}$ or the $\delta 128.39 \mathrm{ppm}$ resonance of $\mathrm{C}_{6} \mathrm{D}_{6}$. Coupling constants are reported in Hz. Infrared (IR) spectra were recorded as thin films on a Perkin-Elmer Spectrum 1000 FTIR. Optical rotations were measured on a Rudolph Autopol III polarimeter using a quartz cell with $1 \mathrm{~mL}$ capacity and a $10 \mathrm{~cm}$ path length. Mass spectra were recorded on a VG 70250-S spectrometer manufactured by Micromass Corp. (Manchester UK).

Analytical thin layer chromatography (TLC) was performed on Kieselgel $60 \mathrm{~F}_{254}$ glass plates precoated with a $0.25 \mathrm{~mm}$ thickness of silica gel. The TLC plates were visualized with UV light and/or by staining with Hanessian stain (a mixture of ceric sulfate and ammonium molybdate in aqueous sulfuric acid), $\mathrm{KMnO}_{4}$, or $p$-anisaldehyde solutions. Column chromatography was generally performed using Kieselgel 60 (230-400 mesh) silica gel. Unless noted otherwise, all compounds isolated by chromatography were sufficiently pure by ${ }^{1} \mathrm{H}$ NMR analysis for use in subsequent reactions. High resolution mass spectra were measured on a VG 70-250-S Micromass spectrometer at the University of Michigan Mass Spectrometry Laboratory. Elemental analyses were performed by the University of Michigan CHN Laboratory.

HPLC purifications were performed by using a HPLC system composed of two Rainin HPXL pumps connected to various Dynamax ${ }^{\circledR}$ axial compression columns packed with Rainin $60 \AA$ irregular silica gel. Samples were loaded into the system with a $2 \mathrm{~mL}$ Rheodyne 7125 injector and were detected using either a Rainin Dynamax ${ }^{\circledR}$ UV-C detector or a Rainin 
Dynamax $^{\circledR}$ RI-1 detector. Integration of the various signals was performed using the reprocessing program within the Dynamax ${ }^{\circledR}$ HPLC Method Manager.

\section{EXPERIMENTAL PROCEDURES.}

\section{A. First Generation Synthesis of Fragment 7.}

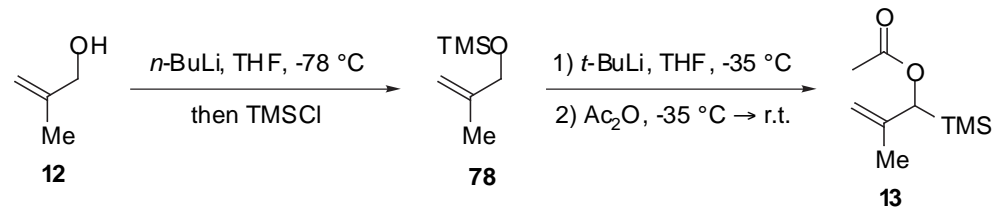

1-Trimethylsilyl-1-acetoxy-2-methyl-2-propene (13). ${ }^{2,3}$ A 250-mL three-necked round bottom flask fitted with a pressure-equalizing funnel, $\mathrm{N}_{2}$ inlet, and rubber septum was charged with $80 \mathrm{~mL}$ of THF and $4.00 \mathrm{~mL}(47.5 \mathrm{mmol})$ of 2-methyl-2-propen-1-ol (12). After the solution was cooled to $-78{ }^{\circ} \mathrm{C}$ in a dry ice/acetone bath, $22.3 \mathrm{~mL}$ (52.3 mmol, 2.35 $\mathrm{M}$ in hexanes) of $n$-BuLi was added dropwise and the solution was stirred at $-78{ }^{\circ} \mathrm{C}$ for $30 \mathrm{~min}$ A solution of TMSCl $(6.65 \mathrm{~mL}, 52.3 \mathrm{mmol})$ in $5 \mathrm{~mL}$ of THF and added dropwise to the reaction mixture through the addition funnel, rinsed with $5 \mathrm{~mL}$ of THF. The resulting light yellow solution was stirred at $-78{ }^{\circ} \mathrm{C}$ for $30 \mathrm{~min}$ A solution of $t$-BuLi $(38.0 \mathrm{~mL}, 57.0 \mathrm{mmol}, 1.5 \mathrm{M}$ in pentane) was added through the addition funnel over a 15 min period. The resulting dark yellow slurry was stirred at $-78{ }^{\circ} \mathrm{C}$ for $10 \mathrm{~min}$, then warmed to $-40{ }^{\circ} \mathrm{C}$ (dry ice $/ \mathrm{CH}_{3} \mathrm{CN}$ ), and the dark yellow solution was maintained at -40 to $-30{ }^{\circ} \mathrm{C}$ for $3 \mathrm{~h}$. A solution of $\mathrm{Ac}_{2} \mathrm{O}(6.3 \mathrm{~mL}, 67 \mathrm{mmol})$ in $5 \mathrm{~mL}$ of THF was added rapidly through the addition funnel, rinsing with $5 \mathrm{~mL}$ of THF, and the resulting slurry was allowed to warm to room temperature. The mixture was carefully quenched by the addition of $\mathrm{H}_{2} \mathrm{O}$, then the mixture was diluted with $100 \mathrm{~mL}$ of $\mathrm{Et}_{2} \mathrm{O}$. The organic layer was washed with $\mathrm{H}_{2} \mathrm{O}$, saturated aqueous $\mathrm{NaHCO}_{3}$, and saturated $\mathrm{NaCl}$ solution, dried over $\mathrm{MgSO}_{4}$, and concentrated to afford crude $\mathbf{1 3}^{2,3}$ as a reddish yellow oil. This material was used in 
the next step without further purification: ${ }^{1} \mathrm{H} \mathrm{NMR}\left(500 \mathrm{MHz}, \mathrm{CDCl}_{3}\right) \delta 5.02(\mathrm{~s}, 1 \mathrm{H}), 4.73(\mathrm{~d}, J$ $=1.5 \mathrm{~Hz}, 1 \mathrm{H}), 4.70(\mathrm{~d}, J=1.5 \mathrm{~Hz}, 1 \mathrm{H}), 2.08(\mathrm{~s}, 3 \mathrm{H}), 1.71(\mathrm{~s}, 3 \mathrm{H}), 0.07(\mathrm{~s}, 9 \mathrm{H})$.

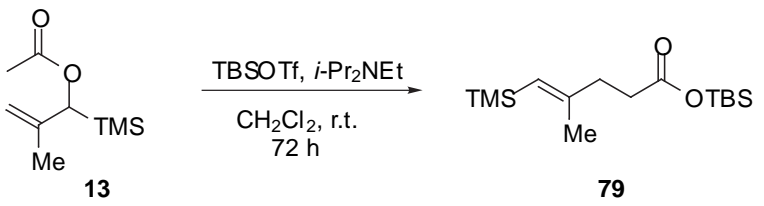

t-Butyldimethylsilyl (E)-4-methyl-5-trimethylsilyl-4-pentenoate (79). A solution of $\alpha$-acetoxysilane 13 (the crude product from the preceding step) in $95 \mathrm{~mL}$ of dry $\mathrm{CH}_{2} \mathrm{Cl}_{2}$ was flushed with $\mathrm{N}_{2}$ and cooled in an ice bath. To this solution was added $i$ - $\operatorname{Pr}_{2} \mathrm{NEt}(16.6 \mathrm{~mL}, 95.1$ mmol), followed by $14.2 \mathrm{~mL}(61.8 \mathrm{mmol})$ of TBSOTf. The ice bath was removed, and the red solution was stirred at room temperature for $72 \mathrm{~h}$. The mixture was then cooled in an ice bath and diluted with saturated aqueous $\mathrm{NaHCO}_{3}$ and extracted with $150 \mathrm{~mL}$ of $\mathrm{CH}_{2} \mathrm{Cl}_{2}$. The organic layer was washed with $1 \mathrm{NHSO}_{4}$ (x2) and saturated $\mathrm{NaCl}$ solution, dried over $\mathrm{Na}_{2} \mathrm{SO}_{4}$, and concentrated to give $23.4 \mathrm{~g}$ of crude 79 as a red oily solid which was used in the next step without further purification: ${ }^{1} \mathrm{H} \mathrm{NMR}\left(500 \mathrm{MHz} \mathrm{CDCl}_{3}\right) \delta 5.19(\mathrm{~s}, 1 \mathrm{H}), 2.47(\mathrm{~m}, 2 \mathrm{H}), 2.35(\mathrm{~m}$, $2 \mathrm{H}), 1.79$ (s, $3 \mathrm{H}), 0.93$ (s, $9 \mathrm{H}), 0.25$ (s, $6 \mathrm{H}), 0.08$ (s, $9 \mathrm{H})$.
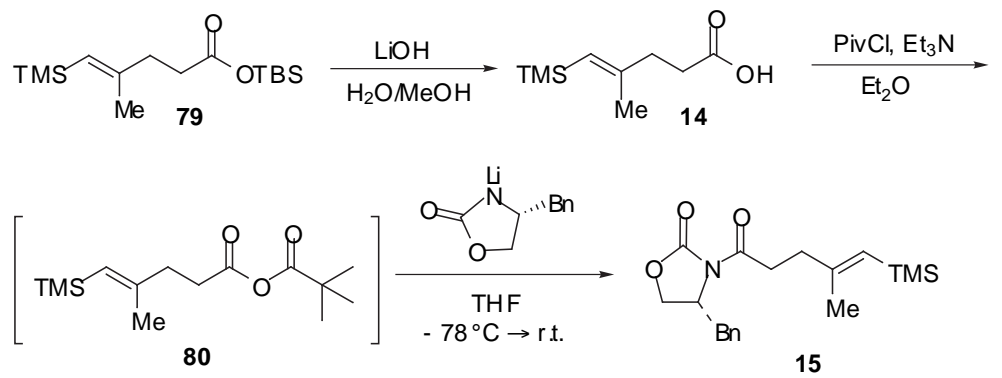

(R)-4-Benzyl-3-[4-methyl-5-(trimethylsilanyl)-pent-4-enoyl]-oxazolidin-2-one (15).

Ester 79 (30 g, $97.0 \mathrm{mmol}$, the crude product from the preceding step) was dissolved in $\mathrm{MeOH} / \mathrm{H}_{2} \mathrm{O} 1: 1(200 \mathrm{~mL})$ and cooled to $0{ }^{\circ} \mathrm{C}$. To this solution was added $\mathrm{LiOH} \bullet \mathrm{H}_{2} \mathrm{O}(16.4 \mathrm{~g}$, $391 \mathrm{mmol}$ ) and the resulting mixture allowed to warm to $23{ }^{\circ} \mathrm{C}$. After $3 \mathrm{~h}$, the reaction mixture was extracted with diethyl ether (x3). $\mathrm{CH}_{2} \mathrm{Cl}_{2}$ was added to the aqueous phase followed by slow 
addition of $\mathrm{HCl}(1 \mathrm{~N})$ until the $\mathrm{pH}$ of the aqueous phase was $\sim 2$. The layers were separated and the aqueous phase was extracted with $\mathrm{CH}_{2} \mathrm{Cl}_{2}(\mathrm{x} 4)$. All of the $\mathrm{CH}_{2} \mathrm{Cl}_{2}$ extracts were combined, washed with saturated $\mathrm{NaCl}$ solution, dried over $\mathrm{Na}_{2} \mathrm{SO}_{4}$, filtered, and concentrated to give 14 (12.7 $\mathrm{g}, 70 \%$ from 12) as a red/orange oil. This material was used without further purification in the next step.

Acid 14 (12.7 g, $68.2 \mathrm{mmol}, 1.3$ equiv) was placed in a $500 \mathrm{~mL}$ three-neck round-bottom flask, dissolved in dry ether $(230 \mathrm{~mL})$ under nitrogen, and cooled to $0{ }^{\circ} \mathrm{C}$. To the cooled solution was added $\mathrm{Et}_{3} \mathrm{~N}(11 \mathrm{~mL}, 78.9 \mathrm{mmol}, 1.5$ equiv) followed by pivaloyl chloride $(8.4 \mathrm{~mL}, 68.2$ mmol, 1.3 equiv). The ice bath was removed and the reaction mixture warmed to $23{ }^{\circ} \mathrm{C}$ and stirred for $1 \mathrm{~h}$. The resulting solution was then cooled to $0{ }^{\circ} \mathrm{C}$. One of the necks of the flask was equipped with a filter frit (Schlenk apparatus) and the reaction mixture filtered under nitrogen into a second dry $1000 \mathrm{~mL}$ round-bottom flask, with washing of the filtered solid (ether, $30 \mathrm{~mL} \mathrm{x}$ 2). The filtering apparatus was removed and the orange filtrate was cooled to $-78{ }^{\circ} \mathrm{C}$ and then diluted with dry THF (130 mL).

A separate 250-mL round bottom flask, under nitrogen, was charged with $9.44 \mathrm{~g}$ (53.3 mmol, 1 equiv) of $(R)$-4-(phenylmethyl)-2-oxazolidinone, a few crystals of 1,10-phenanthroline, and $100 \mathrm{~mL}$ of THF $(100 \mathrm{~mL})$ and cooled to $-78{ }^{\circ} \mathrm{C}$ in a dry ice/acetone bath. A solution of $n$ BuLi (2.35 $\mathrm{M}$ in hexanes) was added dropwise until the red color persisted for $10 \mathrm{~min}$ The lithiated oxazolidinone solution was then added to the chilled mixed anhydride solution via cannula over $40 \mathrm{~min}$ The resulting solution was stirred at $-78{ }^{\circ} \mathrm{C}$ for $30 \mathrm{~min}$, then poured into saturated aqueous $\mathrm{NH}_{4} \mathrm{Cl}$ solution $(400 \mathrm{~mL})$. The layers were separated and the aqueous layer was extracted with $\mathrm{CH}_{2} \mathrm{Cl}_{2}(\mathrm{x} 3)$. The combined organic layers were washed with saturated $\mathrm{NaCl}$ solution, dried over $\mathrm{Na}_{2} \mathrm{SO}_{4}$, and concentrated in vacuo. Purification of the crude product by flash chromatography $\left(\mathrm{SiO}_{2}, 10 \%\right.$ EtOAc/hexanes) gave $14.9 \mathrm{~g}$ of $\mathbf{1 5}$ (81\% from 14) as a viscous orange oil: $[\alpha]_{D}^{26}-53.0^{\circ}\left(c=0.39, \mathrm{CH}_{2} \mathrm{Cl}_{2}\right) ;{ }^{1} \mathrm{H}$ NMR $\left(500 \mathrm{MHz}, \mathrm{CDCl}_{3}\right) \delta 7.34(\mathrm{tt}, J=7.2,1.3$ $\mathrm{Hz}, 2 \mathrm{H}), 7.28$ (tt, $J=7.3,1.2 \mathrm{~Hz}, 1 \mathrm{H}), 7.21(\mathrm{dd}, J=7.6,1.5 \mathrm{~Hz}, 2 \mathrm{H}), 5.25$ (s, $1 \mathrm{H}), 4.67$ (dddd, $J=10.7,6.6,3.3,3.3 \mathrm{~Hz}, 1 \mathrm{H}), 4.19\left(\mathrm{~A}\right.$ of $\left.\mathrm{ABX}, J_{\mathrm{AB}}=16.4 \mathrm{~Hz}, J_{\mathrm{AX}}=9.0 \mathrm{~Hz}, 1 \mathrm{H}\right), 4.17(\mathrm{~B}$ of 
$\left.\mathrm{ABX}, J_{\mathrm{AB}}=9.3 \mathrm{~Hz}, J_{\mathrm{BX}}=3.1 \mathrm{~Hz}, 1 \mathrm{H}\right), 3.29(\mathrm{dd}, J=13.4,3.4 \mathrm{~Hz}, 1 \mathrm{H}), 3.15(\mathrm{ddd}, J=16.6,9.3$, $6.4 \mathrm{~Hz}, 1 \mathrm{H}), 3.03(\mathrm{ddd}, J=16.6,9.3,6.4 \mathrm{~Hz}, 1 \mathrm{H}), 2.75(\mathrm{dd}, J=13.4,9.5 \mathrm{~Hz}, 1 \mathrm{H}), 2.45$ (m, 2 $\mathrm{H}), 1.84(\mathrm{~s}, 3 \mathrm{H}), 0.10(\mathrm{~s}, 9 \mathrm{H}) ;{ }^{13} \mathrm{CNMR}\left(125 \mathrm{MHz}, \mathrm{CDCl}_{3}\right) \delta 172.8,153.4,152.9,135.2,129.4$ (2), 128.9 (2), 127.3, 123.9, 66.1, 55.1, 34.9, 36.4, 34.0, 21.7, 0.0 (3); FT-IR (thin film) 3064, 3029, 2955, 1785, 1701, 1619, 1498, 1481, 1454, 1444, 1387, 1353, 1248, 1212, 1109, 1076, 1051, 1016, 840, 762, 747, $702 \mathrm{~cm}^{-1}$; HRMS $\left(\mathrm{CI} / \mathrm{NH}_{3}\right)$ calcd for $\left[\mathrm{C}_{19} \mathrm{H}_{27} \mathrm{NO}_{3} \mathrm{Si}+\mathrm{H}\right]^{+} 346.1838$, found $346.1826 \mathrm{~m} / \mathrm{z}$.
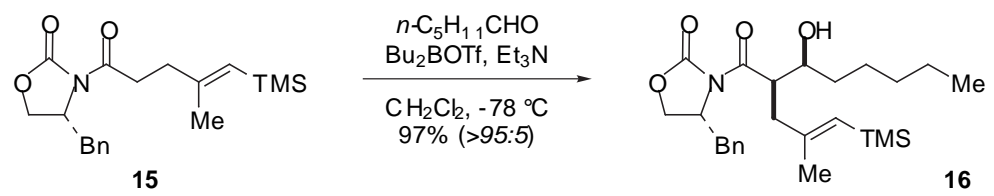

(4R)-4-Benzyl-3-[(2R,3S)-2-(2-methyl-3-trimthylsilyl-E-2-propen-1-yl)-3-hydroxy-

octanoyl]-oxazolidin-2-one (16). A 250-mL round bottom flasked was charged with $3.24 \mathrm{~g}$ (9.37 mmol) of oxazolidinone 15 and $20 \mathrm{~mL}$ of $\mathrm{CH}_{2} \mathrm{Cl}_{2}$. The solution was cooled in an ice bath, then $2.83 \mathrm{~mL}(11.3 \mathrm{mmol})$ of $\mathrm{Bu}_{2} \mathrm{BOTf}$ was added dropwise, followed by $1.70 \mathrm{~mL}(12.2 \mathrm{mmol})$ of $\mathrm{Et}_{3} \mathrm{~N}$. The resulting light yellow solution was stirred at $0{ }^{\circ} \mathrm{C}$ for $10 \mathrm{~min}$ The ice bath was replaced with a dry ice/acetone bath $\left(-78{ }^{\circ} \mathrm{C}\right)$ and $1.35 \mathrm{~mL}(11.3 \mathrm{mmol})$ of hexanal (freshly distilled) was added by syringe over a 5 min period. The reaction mixture was stirred at $-78{ }^{\circ} \mathrm{C}$ for $1 \mathrm{~h}$, warmed to $0{ }^{\circ} \mathrm{C}$ for $2 \mathrm{~h}$, and quenched by addition of $15 \mathrm{~mL}$ of $\mathrm{pH} 7$ buffer and $15 \mathrm{~mL}$ of MeOH. Ten $\mathrm{mL}$ of 2:1 MeOH/30\% aqueous $\mathrm{H}_{2} \mathrm{O}_{2}$ solution was added dropwise and the biphasic mixture was stirred vigorously at room temperature for $1 \mathrm{~h}$. The mixture was diluted with 100 $\mathrm{mL}$ of $\mathrm{H}_{2} \mathrm{O}$ and the layers were separated. The aqueous layer was washed with $\mathrm{CH}_{2} \mathrm{Cl}_{2}(2 \times)$ and the combined organic layers were washed with saturated aqueous $\mathrm{NaHCO}_{3}$, dried over $\mathrm{MgSO}_{4}$, and concentrated. Purification of the crude product by flash chromatography $\left(\mathrm{SiO}_{2}, 15 \%\right.$ EtOAc/hexanes) gave $3.62 \mathrm{~g}(97 \%)$ of $\mathbf{1 6}$ as a pale yellow oil: $[\alpha]^{24}-35.8^{\circ}\left(c=0.65, \mathrm{CHCl}_{3}\right)$; ${ }^{1} \mathrm{H}$ NMR $\left(500 \mathrm{MHz}, \mathrm{CDCl}_{3}\right) \delta 7.34(\mathrm{t}, J=7.1 \mathrm{~Hz}, 2 \mathrm{H}), 7.28(\mathrm{t}, J=7.1 \mathrm{~Hz}, 1 \mathrm{H}), 7.21(\mathrm{~d}, J=7.1$ Hz, 2 H), 5.29 (s, 1 H), 4.69 (dddd, $J=10.5,6.5,3.1,3.1 \mathrm{~Hz}, 1 \mathrm{H}), 4.38$ (ddd, $J=10.5,4.0,4.0$ 
$\mathrm{Hz}, 1 \mathrm{H}), 4.17\left(\mathrm{~A}\right.$ of $\left.\mathrm{ABX}, J_{\mathrm{AB}}=17.1 \mathrm{~Hz}, J_{\mathrm{AX}}=7.8 \mathrm{~Hz}, 1 \mathrm{H}\right), 4.12\left(\mathrm{~B}\right.$ of $\mathrm{ABX}, J_{\mathrm{AB}}=9.0 \mathrm{~Hz}, J_{\mathrm{BX}}$ $=2.9 \mathrm{~Hz}, 1 \mathrm{H}), 3.87(\mathrm{~m}, 1 \mathrm{H}), 3.34(\mathrm{dd}, J=13.2,2.9 \mathrm{~Hz}, 1 \mathrm{H}), 2.63(\mathrm{dd}, J=13.9,10.5 \mathrm{~Hz}, 1 \mathrm{H})$, $2.52(\mathrm{dd}, J=13.2,10.7 \mathrm{~Hz}, 1 \mathrm{H}), 2.48(\mathrm{~d}, J=3.2 \mathrm{~Hz}, 1 \mathrm{H}), 2.41(\mathrm{dd}, J=13.9,10.5 \mathrm{~Hz}, 1 \mathrm{H})$, $1.86(\mathrm{~s}, 3 \mathrm{H}), 1.57-1.50(\mathrm{~m}, 3 \mathrm{H}), 1.34-1.24(\mathrm{~m}, 5 \mathrm{H}), 0.89(\mathrm{t}, J=6.8 \mathrm{~Hz}, 3 \mathrm{H}), 0.07(\mathrm{~s}, 9 \mathrm{H}) ;{ }^{13} \mathrm{C}$ NMR (125 MHz, $\left.\mathrm{CDCl}_{3}\right) \delta 175.5,153.5,152.4,135.3,129.2$ (2), 129.0 (2), 127.3, 125.8, 72.7, 65.9, 55.6, 45.9, 10.1, 38.2, 33.7, 31.7, 25.7, 22.6, 22.0, 14.0, 0.0 (3); FT-IR (thin film) 3502, $3030,2955,2931,2860,1783,1697,1616,1383,1350,1247,1195,1107,1051,1016,838,700$ $\mathrm{cm}^{-1}$; HRMS $\left(\mathrm{CI} / \mathrm{NH}_{3}\right)$ calcd for $\left[\mathrm{C}_{25} \mathrm{H}_{39} \mathrm{NO}_{4} \mathrm{Si}+\mathrm{H}\right]^{+} 446.2726$, found $446.2716 \mathrm{~m} / \mathrm{z}$.
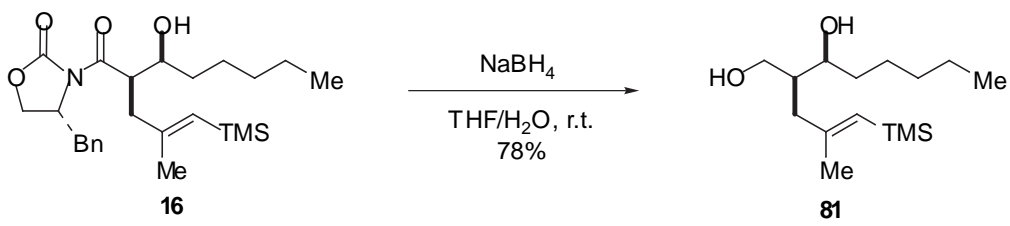

$(1 E, 4 R, 5 S)-5-H y d r o x y-2-m e t h y l-4-h y d r o x y m e t h y l-1-t r i m e t h y l s i l y l-1 \quad$ decene $(81)$.

To a $0{ }^{\circ} \mathrm{C}$ solution of aldol $16(1.67 \mathrm{~g}, 3.75 \mathrm{mmol})$ in $32 \mathrm{~mL}$ of THF was added dropwise a solution of $0.567 \mathrm{~g}(15.0 \mathrm{mmol})$ of $\mathrm{NaBH}_{4}$ in $8 \mathrm{~mL}$ of deionized $\mathrm{H}_{2} \mathrm{O}$. Once addition was complete, the ice bath was removed and the biphasic mixture was stirred vigorously at room temperature for $8 \mathrm{~h}$. The mixture was then recooled in an ice bath and $50 \mathrm{~mL}$ of $1 \mathrm{~N} \mathrm{HCl}$ was added carefully to quench the excess hydride reagent. The aqueous layer was extracted with 50 $\mathrm{mL}$ of $\mathrm{Et}_{2} \mathrm{O}(3 \times)$. The combined organic layers were washed with saturated $\mathrm{NaCl}$ solution, dried over $\mathrm{MgSO}_{4}$, and concentrated. Purification of the crude product by flash chromatography $\left(\mathrm{SiO}_{2}, 25 \%\right.$ EtOAc/hexanes then $30 \%$ EtOAc/hexanes) gave $0.801 \mathrm{~g}(78 \%)$ of the diol as a yellowish white solid: $[\alpha]^{25}+3.5^{\circ}\left(c=1.38, \mathrm{CHCl}_{3}\right) ;{ }^{1} \mathrm{H} \mathrm{NMR}\left(500 \mathrm{MHz}, \mathrm{CDCl}_{3}\right) \delta 5.26(\mathrm{~d}, J=$ $1.0 \mathrm{~Hz}, 1 \mathrm{H}), 3.83$ (m, $1 \mathrm{H}), 3.75$ (m, $1 \mathrm{H}), 3.68$ (m, $1 \mathrm{H}), 2.44$ (bs, $1 \mathrm{H}), 2.30$ (bs, $1 \mathrm{H}), 2.10$ (d, $J=8.1 \mathrm{~Hz}, 2 \mathrm{H}), 1.93(\mathrm{~m}, 1 \mathrm{H}), 1.79(\mathrm{~d}, J=1.0 \mathrm{~Hz}, 3 \mathrm{H}), 1.54-1.42$ (m, $3 \mathrm{H}), 1.34-1.25$ (m, $5 \mathrm{H})$, $0.89(\mathrm{t}, J=7.0 \mathrm{~Hz}, 3 \mathrm{H}), 0.09$ (s, $9 \mathrm{H}) ;{ }^{13} \mathrm{CNMR}\left(125 \mathrm{MHz}, \mathrm{CDCl}_{3}\right) \delta$ 153.1, 126.0, 74.8, 64.8, 42.1, 39.2, 33.1, 31.8, 25.9, 22.6, 21.3, 14.0, 0.0 (3); FT-IR (thin film) 3291, 2953, 2931, 2859, 
$1616,1441,1377,1248,1028,859,836,690 \mathrm{~cm}^{-1}$; HRMS $\left(\mathrm{CI} / \mathrm{NH}_{3}\right)$ calcd for $\left[\mathrm{C}_{15} \mathrm{H}_{32} \mathrm{O}_{2} \mathrm{Si}+\mathrm{H}\right]^{+}$ 273.2250, found $273.2258 \mathrm{~m} / \mathrm{z}$.
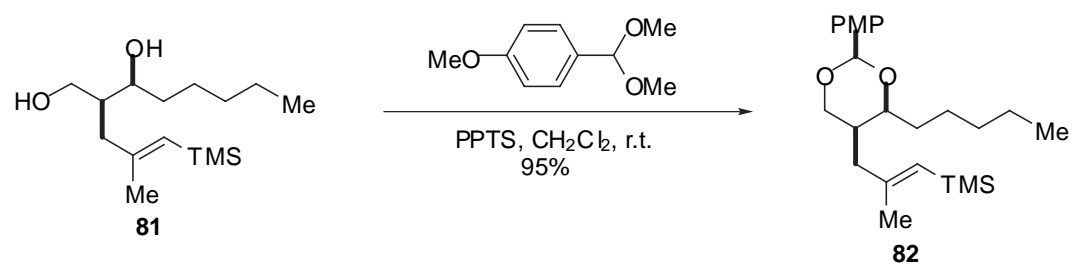

(2R,4S,5S)-5-(2-methyl-3-trimethylsilyl-E-prop-2-en-1-yl)-2-(4-methoxyphenyl)-4-

pentyl-1,3-dioxane (82). A solution of diol 81 from the preceding experiment (319 $\mathrm{mg}, 1.17$ $\mathrm{mmol})$ in $6 \mathrm{~mL}$ of dry $\mathrm{CH}_{2} \mathrm{Cl}_{2}$ was treated with anisaldehyde dimethyl acetal $(640 \mathrm{mg}, 3.51$ mmol) and PPTS (15 mg). The resulting solution was stirred at room temperature for $3 \mathrm{~h}$. The reaction mixture was diluted with $50 \mathrm{~mL}$ of $\mathrm{Et}_{2} \mathrm{O}$, washed with $1 N \mathrm{KHSO}_{4}$, saturated aqueous $\mathrm{NaHCO}_{3}$, and saturated $\mathrm{NaCl}$ solution, dried over $\mathrm{MgSO}_{4}$, and concentrated. Purification of the crude product by flash chromatography $\left(\mathrm{SiO}_{2}, 5 \%\right.$ EtOAc/hexanes) gave $434 \mathrm{mg}(95 \%)$ of the $p$ methoxybenzylidene acetal $\mathbf{8 2}$ as a clear oil. This material was used immediately in the next step: ${ }^{1} \mathrm{H}$ NMR (500 MHz, $\left.\mathrm{CDCl}_{3}\right) \delta 7.42(\mathrm{~d}, J=8.8 \mathrm{~Hz}, 2 \mathrm{H}), 6.89(\mathrm{~d}, J=8.6 \mathrm{~Hz}, 2 \mathrm{H}), 5.47(\mathrm{~s}, 1 \mathrm{H})$, $5.34(\mathrm{~s}, 1 \mathrm{H}), 4.14(\mathrm{~d}, J=11.0 \mathrm{~Hz}, 1 \mathrm{H}), 3.96(\mathrm{~m}, 1 \mathrm{H}), 3.86(\mathrm{~d}, J=10.5 \mathrm{~Hz}, 1 \mathrm{H}), 3.80(\mathrm{~s}, 3 \mathrm{H})$, $2.54(\mathrm{dd}, J=13.9,11.2 \mathrm{~Hz}, 1 \mathrm{H}), 2.26(\mathrm{~d}, J=13.9 \mathrm{~Hz}, 1 \mathrm{H}), 1.78(\mathrm{~s}, 3 \mathrm{H}), 1.65(\mathrm{~m}, 1 \mathrm{H}), 1.56$ (m, $1 \mathrm{H}), 1.51-1.44(\mathrm{~m}, 2 \mathrm{H}), 1.31-1.25(\mathrm{~m}, 5 \mathrm{H}), 0.89(\mathrm{t}, J=6.7 \mathrm{~Hz}, 3 \mathrm{H}), 0.10(\mathrm{~s}, 9 \mathrm{H})$.
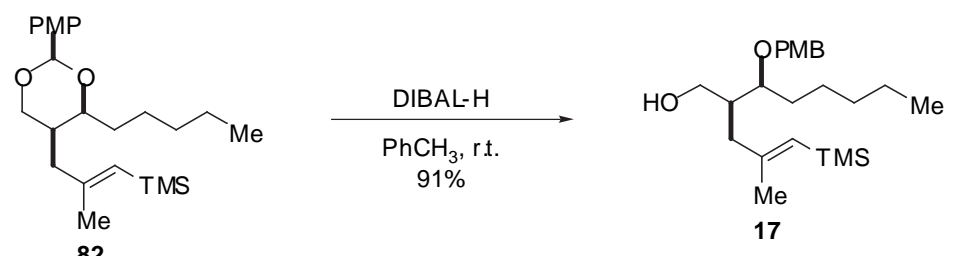

(1E,4R,5S) 4-Hydroxymethyl-5- $\quad p$-methoxybenzyloxy-2-methyl-1-trimethylsilyl-1decene (17). A solution of the p-methoxybenzylidene acetal 82 (434 mg) in $20 \mathrm{~mL}$ of dry toluene was cooled to $-10{ }^{\circ} \mathrm{C}$ in an ice/acetone bath. DIBAL-H $(2.3 \mathrm{~mL}, 2.22 \mathrm{mmol}, 1.0 \mathrm{M}$ in hexane) was added dropwise via syringe, and the yellowish solution was allowed to warm to 
room temperature and stirred for $32 \mathrm{~h}$. The reaction mixture was carefully quenched with saturated aqueous potassium sodium tartrate solution and stirred vigorously for $1 \mathrm{~h}$ to dissolve the aluminum salts. The biphasic mixture was diluted with $\mathrm{Et}_{2} \mathrm{O}$, and the organic layer was washed with saturated aqueous potassium sodium tartrate solution. The aqueous layer was washed with $\mathrm{Et}_{2} \mathrm{O}(3 \times)$, and the combined organic layers were washed with saturated $\mathrm{NaCl}$ solution, dried over $\mathrm{MgSO}_{4}$, and concentrated. Purification of the crude product by flash chromatography $\left(\mathrm{SiO}_{2}, 15 \%\right.$ EtOAc/hexanes then 20\% EtOAc/hexanes) gave $396 \mathrm{mg}$ (91\%) of 17 as a yellowish oil: $[\alpha]^{25}-6.1^{\circ}\left(c=1.62, \mathrm{CHCl}_{3}\right) ;{ }^{1} \mathrm{H} \mathrm{NMR}\left(500 \mathrm{MHz}, \mathrm{CDCl}_{3}\right) \delta 7.27(\mathrm{~d}, J=$ $8.8 \mathrm{~Hz}, 2 \mathrm{H}), 6.89(\mathrm{~d}, J=8.8 \mathrm{~Hz}, 2 \mathrm{H}), 5.24(\mathrm{~s}, 1 \mathrm{H}), 4.56\left(\mathrm{~A}\right.$ of AB, $\left.J_{A B}=11.0 \mathrm{~Hz}, 1 \mathrm{H}\right), 4.43(\mathrm{~B}$ of $\left.\mathrm{AB}, J_{A B}=11.2 \mathrm{~Hz}, 1 \mathrm{H}\right), 3.81(\mathrm{~s}, 3 \mathrm{H}), 3.72(\mathrm{ddd}, J=11.4,8.6,3.3 \mathrm{~Hz}, 1 \mathrm{H}), 3.55$ (ddd, $J=$ 11.2, 7.1, 4.4 Hz, 1 H), 3.48 (ddd, $J=9.0,3.2,3.2 \mathrm{~Hz}, 1 \mathrm{H}), 2.96(\mathrm{dd}, J=7.3,3.4 \mathrm{~Hz}, 1 \mathrm{H}), 2.28$ $(\mathrm{m}, 1 \mathrm{H}), 2.02\left(\mathrm{~A}\right.$ of ABX, $\left.J_{A B}=13.4 \mathrm{~Hz}, J_{B X}=7.4 \mathrm{~Hz}, 1 \mathrm{H}\right), 1.97\left(\mathrm{~B}\right.$ of ABX, $J_{A B}=13.4 \mathrm{~Hz}, J_{B X}$ $=6.7 \mathrm{~Hz}, 1 \mathrm{H}), 1.79(\mathrm{~d}, J=1.0 \mathrm{~Hz}, 3 \mathrm{H}), 1.51(\mathrm{~m}, 1 \mathrm{H}), 1.49-1.41(\mathrm{~m}, 2 \mathrm{H}), 1.33-1.20(\mathrm{~m}, 5 \mathrm{H})$, 0.89 (t, $J=7.2 \mathrm{~Hz}, 3 \mathrm{H}), 0.10$ (s, $9 \mathrm{H}) ;{ }^{13} \mathrm{CNMR}\left(125 \mathrm{MHz}, \mathrm{CDCl}_{3}\right) \delta$ 159.3, 152.6, 130.3, 129.6 (2), 126.1, 113.8 (2), 81.1, 71.4, 64.3, 55.2, 41.2, 39.0, 31.8, 29.1, 25.8, 22.6, 21.2, 14.0, 0.0 (3); FT-IR (thin film) 3436, 2954, 2860, 1614, 1514, 1466, 1303, 1248, 1174, 1038, 862, 837, 734, $690 \mathrm{~cm}^{-1} ; \mathrm{HRMS}\left(\mathrm{CI} / \mathrm{NH}_{3}\right)$ calcd for $\left[\mathrm{C}_{23} \mathrm{H}_{40} \mathrm{O}_{3} \mathrm{Si}+\mathrm{H}\right]^{+} 393.2825$, found $393.2826 \mathrm{~m} / \mathrm{z}$.
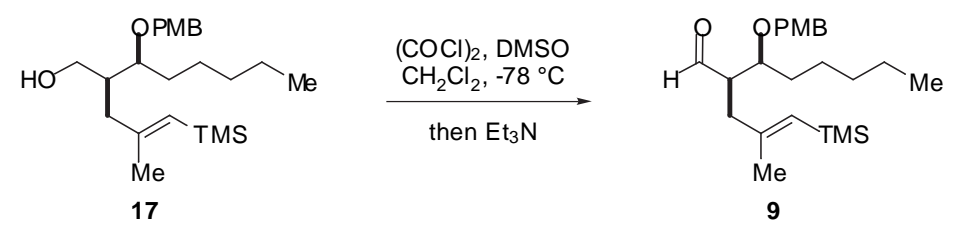

\section{(2R,3S)-2-(2-methyl-3-trimethylsilyl-E-prop-2-en-1-yl)-3-(p-methoxy-benzyloxy)-}

octanal (9). A $25-\mathrm{mL}$ round bottom flask was charged with $106 \mu \mathrm{L}(1.49 \mathrm{mmol})$ of anhydrous DMSO and $6 \mathrm{~mL}$ of dry $\mathrm{CH}_{2} \mathrm{Cl}_{2}$ and cooled to $-78{ }^{\circ} \mathrm{C}$ in a dry ice/acetone bath. Oxalyl chloride $(130 \mu \mathrm{L}, 1.49 \mathrm{mmol})$ was added, and the solution was stirred at $-78{ }^{\circ} \mathrm{C}$ for $10 \mathrm{~min}$ A solution of $451 \mathrm{mg}$ (1.15 mmol) of $\mathbf{1 7}$ in $1.5 \mathrm{~mL}$ of $\mathrm{CH}_{2} \mathrm{Cl}_{2}$ was added to the reaction mixture via cannula, rinsing with $1.5 \mathrm{~mL}$ of $\mathrm{CH}_{2} \mathrm{Cl}_{2}$. The resulting solution was stirred for an additional 10 min $\mathrm{Et}_{3} \mathrm{~N}$ 
(416 $\mu \mathrm{L}, 2.99 \mathrm{mmol}$ ) was added dropwise, the cold bath was removed, and the reaction mixture was warmed to $0{ }^{\circ} \mathrm{C}$ and stirred for $10 \mathrm{~min}$ The resulting cloudy suspension was diluted with $\mathrm{H}_{2} \mathrm{O}$ and the layers were separated. The aqueous layer was washed with $\mathrm{CH}_{2} \mathrm{Cl}_{2}(3 \times)$. The combined organic layers were washed with saturated $\mathrm{NaCl}$ solution, dried over $\mathrm{MgSO}_{4}$, and concentrated to a yellow oil (9) that was used immediately in the following reaction without further purification: ${ }^{1} \mathrm{H} \mathrm{NMR}\left(500 \mathrm{MHz}, \mathrm{CDCl}_{3}\right) \delta 9.76(\mathrm{~d}, J=2.2 \mathrm{~Hz}, 1 \mathrm{H}), 7.24(\mathrm{~d}, J=8.4 \mathrm{~Hz}$, $2 \mathrm{H}), 6.87(\mathrm{~d}, J=8.8 \mathrm{~Hz}, 2 \mathrm{H}), 5.20(\mathrm{~s}, 1 \mathrm{H}), 4.87\left(\mathrm{~A}\right.$ of $\left.\mathrm{AB}, J_{A B}=11.0 \mathrm{~Hz}, 1 \mathrm{H}\right), 4.43(\mathrm{~B}$ of $\mathrm{AB}$, $\left.J_{A B}=11.0 \mathrm{~Hz}, 1 \mathrm{H}\right), 3.80(\mathrm{~s}, 3 \mathrm{H}), 3.67(\mathrm{ddd}, J=8.8,4.4,4.4 \mathrm{~Hz}, 1 \mathrm{H}), 2.74(\mathrm{dddd}, J=10.4,4.4$, 4.4, $2.2 \mathrm{~Hz}, 1 \mathrm{H}), 2.56$ (ddd, $J=15.0,8.4,0.7 \mathrm{~Hz}, 1 \mathrm{H}), 2.25$ (ddd, $J=15.0,6.2,1.1 \mathrm{~Hz}, 1 \mathrm{H}$ ), $1.76(\mathrm{~s}, 3 \mathrm{H}), 1.55-1.20(\mathrm{~m}, 8 \mathrm{H}), 0.87$ (t, $J=7.1 \mathrm{~Hz}, 3 \mathrm{H})$.
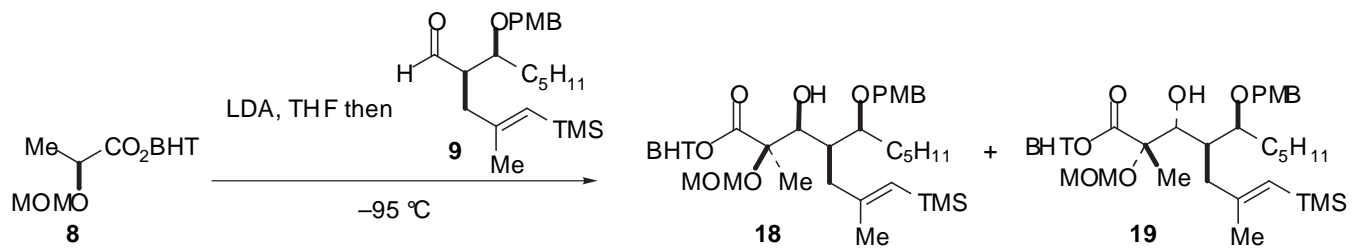

\section{$2^{\prime}, 6^{\prime}$-Di-t-butyl-4'-methylphenyl $(2 R, 3 S, 4 R, 5 S)-3-H y d r o x y-5-p$-methoxybenzyloxy-2-} methoxy-methyleneoxy-2-methyl-4-(E-2'-methyl-3-trimethylsilylprop-2-enyl)decanoate

(18). A solution of $807 \mu \mathrm{L}(5.70 \mathrm{mmol})$ of diisopropylamine in $10 \mathrm{~mL}$ of dry THF was cooled in to $-30{ }^{\circ} \mathrm{C}$ and treated with $2.40 \mathrm{~mL}(5.7 \mathrm{mmol}, 2.4 \mathrm{M}$ in hexanes $)$ of $n$-BuLi. The cold bath was removed and the solution was warmed to $0{ }^{\circ} \mathrm{C}$ for $30 \mathrm{~min}$ and then recooled to $-78{ }^{\circ} \mathrm{C}$. A solution of lactate ester $\mathbf{8}^{4}$ in THF (3.0 mL) and was added dropwise to the LDA solution via syringe, rinsing with an additional $1.0 \mathrm{~mL}$ of THF. The resulting bright yellow solution was warmed to $-50{ }^{\circ} \mathrm{C}$ and stirred at for $10 \mathrm{~min}$, then recooled to $-95{ }^{\circ} \mathrm{C}$. A solution of the crude aldehyde 9 in THF $(2.5 \mathrm{~mL})$ was added dropwise to the enolate solution via syringe while maintaining the internal temperature below $-92{ }^{\circ} \mathrm{C}$, rinsing with an additional $0.5 \mathrm{~mL}$ of THF. The solution was slowly warmed to $-78^{\circ} \mathrm{C}$ over $1 \mathrm{~h}$ and stirred at $-78^{\circ}$ for $1 \mathrm{~h}$. The reaction was quenched by addition of saturated aqueous $\mathrm{NH}_{4} \mathrm{Cl}$, warmed to room temperature, and diluted 
with $100 \mathrm{~mL}$ of $\mathrm{Et}_{2} \mathrm{O}$. The organic layer was washed with $1 \mathrm{~N} \mathrm{KHSO}_{4}$, saturated aqueous $\mathrm{NaHCO}_{3}$, dried over $\mathrm{MgSO}_{4}$, and concentrated. Purification of the crude product by flash chromatography $\left(\mathrm{SiO}_{2}, 6 \%\right.$ to $12 \%$ EtOAc/hexanes) gave $2.20 \mathrm{~g}(78 \%)$ of an inseparable $>11: 1$ mixture (as judged by ${ }^{1} \mathrm{H}-\mathrm{NMR}$ ) of $\mathbf{1 8}$ and the minor aldol isomer $\mathbf{1 9}$ as a yellow oil.

Characterization data for 18: $1 \mathrm{H} \mathrm{NMR}\left(500 \mathrm{MHz}, \mathrm{CDCl}_{3}\right) \delta 7.22(\mathrm{~d}, J=8.6 \mathrm{~Hz}, 2 \mathrm{H})$, $7.14(\mathrm{~s}, 1 \mathrm{H}), 7.13(\mathrm{~s}, 1 \mathrm{H}), 6.83(\mathrm{~d}, J=8.6 \mathrm{~Hz}, 2 \mathrm{H}), 5.28(\mathrm{~s}, 1 \mathrm{H}), 5.15\left(\mathrm{~A}\right.$ of $\mathrm{AB}, J_{A B}=7.6 \mathrm{~Hz}$, $1 \mathrm{H}), 4.88\left(\mathrm{~B}\right.$ of $\left.\mathrm{AB}, J_{A B}=7.6 \mathrm{~Hz}, 1 \mathrm{H}\right), 4.51\left(\mathrm{~A}\right.$ of $\left.\mathrm{AB}, J_{A B}=11.2 \mathrm{~Hz}, 1 \mathrm{H}\right), 4.45(\mathrm{~d}, J=8.3 \mathrm{~Hz}$, $1 \mathrm{H}), 4.27\left(\mathrm{~B}\right.$ of $\left.\mathrm{AB}, J_{A B}=11.5 \mathrm{~Hz}, 1 \mathrm{H}\right), 3.79(\mathrm{~s}, 3 \mathrm{H}), 3.45(\mathrm{~s}, 3 \mathrm{H}), 3.35$ (bd, $\left.J=9.8 \mathrm{~Hz}, 1 \mathrm{H}\right)$, $2.82(\mathrm{~d}, J=8.1 \mathrm{~Hz}, 1 \mathrm{H}), 2.60(\mathrm{~m}, 2 \mathrm{H}), 2.32(\mathrm{~s}, 3 \mathrm{H}), 2.17(\mathrm{~m}, 1 \mathrm{H}), 1.81(\mathrm{~s}, 3 \mathrm{H}), 1.77(\mathrm{~s}, 3 \mathrm{H})$, 1.54-1.43 (m, 2 H), 1.35 (3, 9 H), 1.34 (s, 9 H), 1.33-1.20 (m, $3 \mathrm{H}), 1.19-1.12(\mathrm{~m}, 3 \mathrm{H}), 0.84(\mathrm{t}, J$ $=7.3 \mathrm{~Hz}, 3 \mathrm{H}), 0.10(\mathrm{~s}, 9 \mathrm{H}) ;{ }^{13} \mathrm{CNMR}\left(125 \mathrm{MHz}, \mathrm{CDCl}_{3}\right) \delta 173.0,165.8,159.0,153.0,146.5$, 142.6, 142.2, 134.8, 131.0, 129.5 (2), 127.2, 127.1, 125.4, 113.6 (2), 93.3, 84.6, 79.0, 72.2, 70.7, 56.5, 55.2, 38.3, 36.4, 35.3, 32.2, 31.6, 31.5 (3), 31.4 (3), 29.6, 26.3, 22.8, 21.8, 21.4, 20.0, 14.0, 0.0 (3); FT-IR (thin film) 3571, 2955, 1756, 1614, 1514, 1464, 1417, 1395, 1365, 1302, 1247, 1173, 1145, 1063, 838, 758, $690 \mathrm{~cm}^{-1}$; HRMS (FAB) calcd for $\left[\mathrm{C}_{43} \mathrm{H}_{70} \mathrm{O}_{7} \mathrm{Si}+\mathrm{Na}\right]^{+} 749.4789$, found $749.4778 \mathrm{~m} / \mathrm{z}$.
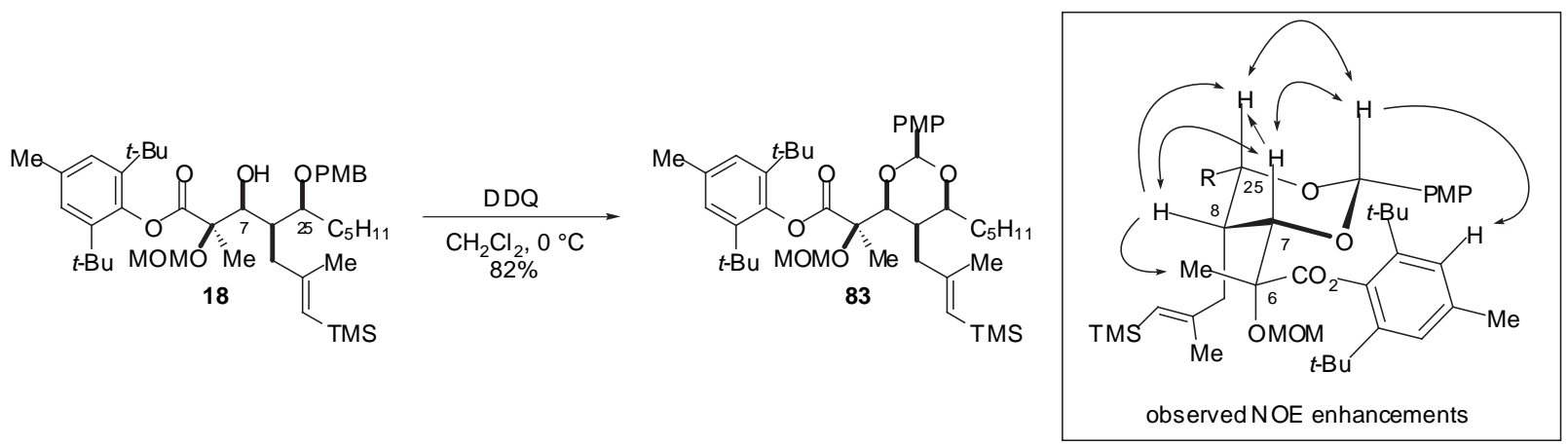

DDQ oxidation of PMB ether 18 gave the p-methoxybenzylidene (PMP) acetal 83. Key ${ }^{1} \mathrm{H}$ NOE enhancements were observed between the $\mathrm{C}(7), \mathrm{C}(25)$, and the acetal methine protons, 
clearly indicating the syn-1,3-diol relationship. Further, ${ }^{1} \mathrm{H}$ NOE enhancements between the $\mathrm{C}(8)-\mathrm{H}$ and $\mathrm{C}(6)-\mathrm{Me}$ as well as between the acetal methine and the aryl ring dicate that $\mathrm{C}(6)$ has $(R)$-configuration, as shown.

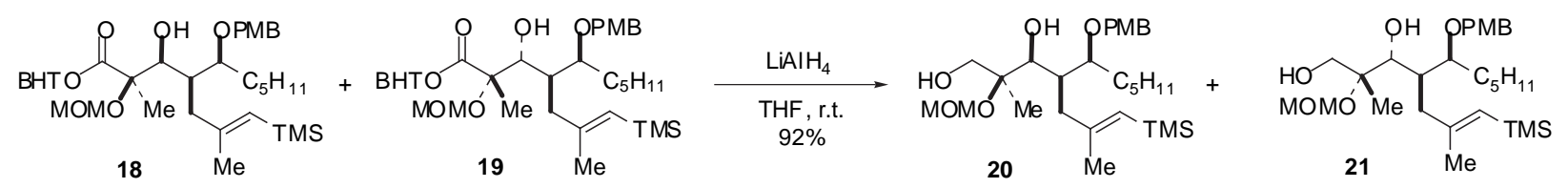

$(2 S, 3 S, 4 R, 5 S)-3-H y d r o x y-5-p$-methoxybenzyloxy-2-methoxymethyleneoxy-2-methyl4-(E-2'-methyl-3'-trimethylsilylprop-2'-enyl)decan-1-ol (20). A $35 \mathrm{~mL}$ round bottom flask was charged with $3.0 \mathrm{~mL}(2.0 \mathrm{mmol})$ of a $0.67 \mathrm{M}$ solution of $\mathrm{LiAlH}_{4}$ in THF. A solution of 600 $\mathrm{mg}(0.82 \mathrm{mmol})$ of esters 18 and $19(>11: 1)$ in $2 \mathrm{~mL}$ of THF was added dropwise followed by rinsing $(0.5 \mathrm{~mL}$ of THF). The resulting solution was stirred at room temperature for $13 \mathrm{~h}$. The excess hydride was quenched by the careful addition of EtOAc $(300 \mu \mathrm{L})$. The resulting solution was diluted with $\mathrm{Et}_{2} \mathrm{O}$ then saturated aqueous Rochelle's salt and the biphasic mixture was stirred vigorously for $8 \mathrm{~h}$. The organic layer was separated and the aqueous was washed with $\mathrm{Et}_{2} \mathrm{O}(3 \times)$. The combined organic layers were washed with saturated $\mathrm{NaCl}$ solution, dried over $\mathrm{MgSO}_{4}$, and concentrated. Purification of the crude product by flash chromatography $\left(\mathrm{SiO}_{2}\right.$, gradient $20 \%$ to $50 \%$ EtOAc/hexanes) gave $363 \mathrm{mg}$ (93\%) of diol 20 as a yellow oil and $27 \mathrm{mg}$ $(6.4 \%)$ of the diastereomeric diol 21. Data for 20: $[\alpha]^{26}{ }_{D}-16.8^{\circ}\left(c=1.71, \mathrm{CHCl}_{3}\right) ;{ }^{1} \mathrm{H}$ NMR $(500$ $\left.\mathrm{MHz}, \mathrm{CDCl}_{3}\right) \delta 7.23(\mathrm{~d}, J=8.8 \mathrm{~Hz}, 2 \mathrm{H}), 6.86(\mathrm{~d}, J=8.6 \mathrm{~Hz}, 2 \mathrm{H}), 5.23(\mathrm{~s}, 1 \mathrm{H}), 4.90(\mathrm{~A}$ of AB, $\left.J_{A B}=7.6 \mathrm{~Hz}, 1 \mathrm{H}\right), 4.75\left(\mathrm{~B}\right.$ of $\left.\mathrm{AB}, J_{A B}=7.3 \mathrm{~Hz}, 1 \mathrm{H}\right), 4.43\left(\mathrm{~A}\right.$ of $\left.\mathrm{AB}, J_{A B}=11.5 \mathrm{~Hz}, 1 \mathrm{H}\right), 4.30$ $\left(\mathrm{B}\right.$ of $\left.\mathrm{AB}, J_{A B}=11.5 \mathrm{~Hz}, 1 \mathrm{H}\right), 3.97(\mathrm{~d}, J=3.7 \mathrm{~Hz}, 1 \mathrm{H}), 3.79(\mathrm{~s}, 3 \mathrm{H}), 3.70(\mathrm{dd}, J=12.5,4.4 \mathrm{~Hz}$, $1 \mathrm{H}), 3.62(\mathrm{dd}, J=12.7,9.3 \mathrm{~Hz}, 1 \mathrm{H}), 3.55(\mathrm{dd}, J=9.3,4.6 \mathrm{~Hz}, 1 \mathrm{H}), 3.43(\mathrm{~s}, 3 \mathrm{H}), 3.35$ (ddd, $J=$ 9.0, 3.2, 3.2 Hz, $1 \mathrm{H}), 2.82(\mathrm{~d}, J=3.9 \mathrm{~Hz}, 1 \mathrm{H}), 2.82(\mathrm{~d}, J=3.9 \mathrm{~Hz}, 1 \mathrm{H}), 2.43$ (d, $J=13.9 \mathrm{~Hz}, 1$ H), 2.18 (ddd, $J=11.5,2.7,2.7 \mathrm{~Hz}, 1 \mathrm{H}), 2.09$ (dd, $J=14.2,11.5 \mathrm{~Hz}, 1 \mathrm{H}), 1.75$ (s, $3 \mathrm{H}), 1.57-$ 
$1.51(\mathrm{~m}, 2 \mathrm{H}), 1.43(\mathrm{~m}, 1 \mathrm{H}), 1.29-1.20(\mathrm{~m}, 2 \mathrm{H}), 1.19-1.12(\mathrm{~m}, 3 \mathrm{H}), 1.16(\mathrm{~s}, 3 \mathrm{H}), 0.85(\mathrm{t}, J=$ $7.2 \mathrm{~Hz}, 3 \mathrm{H}), 0.10$ (s, $9 \mathrm{H}) ;{ }^{13} \mathrm{C} \mathrm{NMR}\left(125 \mathrm{MHz}, \mathrm{CDCl}_{3}\right) \delta 159.3,153.1,130.2,129.9(2), 125.8$, $113.8(2), 91.2,82.4,79.6,72.5,71.1,67.0,55.7,55.2,38.6,37.6,31.7,29.3,26.2,22.7,21.4$, 16.2, 14.1, 0.0 (3); FT-IR (thin film) 3437, 2954, 2858, 1613, 1514, 1466, 1302, 1248, 1173, 1142, 1115, 1037, 870, $837 \mathrm{~cm}^{-1}$; HRMS (FAB) calcd for $\left[\mathrm{C}_{28} \mathrm{H}_{50} \mathrm{O}_{6} \mathrm{Si}+\mathrm{Na}\right]^{+} 533.3274$, found $533.3257 \mathrm{~m} / \mathrm{z}$.

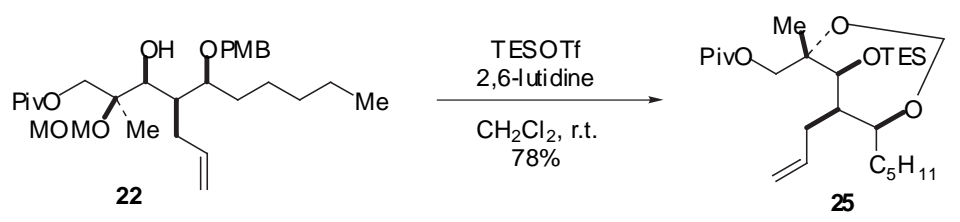

\section{$(2 S, 3 S, 4 R, 5 S)-2,5-O$-Methylidene-2-methyl-4-(prop-2'-en-1'-yl)-3-}

[(triethylsilyl)oxy]-1-trimethylacetoxy-decane (25). ${ }^{4}$ A flame-dried $25-\mathrm{mL}$ round bottom flask was charged with $224 \mathrm{mg}(0.441 \mathrm{mmol})$ of pivalate $22^{4}$ and $7.5 \mathrm{~mL}$ of $\mathrm{CH}_{2} \mathrm{Cl}_{2}$. The solution was treated sequentially with $410 \mu \mathrm{L}(3.52 \mathrm{mmol})$ of 2,6 -lutidine and $398 \mu \mathrm{L}(1.76 \mathrm{mmol})$ of TESOTf, and the resulting mixture stirred at $23{ }^{\circ} \mathrm{C}$ for $4 \mathrm{~h}$. Saturated aqueous $\mathrm{NaHCO}_{3}$ was added, then the layers were separated and the aqueous layer was washed with $\mathrm{CH}_{2} \mathrm{Cl}_{2}(3 \times)$. The combined organic layers were washed with $1 \mathrm{~N} \mathrm{KHSO}_{4}$ and saturated aqueous $\mathrm{NaHCO}_{3}$, dried over $\mathrm{MgSO}_{4}$, and concentrated. Purification of the crude product by flash chromatography $\left(\mathrm{SiO}_{2}, 4 \% \mathrm{EtOAc} /\right.$ hexanes then $5 \%$ EtOAc/hexanes) gave $161 \mathrm{mg}(78 \%)$ of acetal 25 as a colorless oil: $[\alpha]_{\mathrm{D}}^{25}+16.7^{\circ}\left(c=0.91, \mathrm{CHCl}_{3}\right) ;{ }^{1} \mathrm{H} \mathrm{NMR}\left(500 \mathrm{MHz}, \mathrm{CDCl}_{3}\right) \delta 5.82(\mathrm{ddd}, J=18.7$, $10.3,8.6,5.9 \mathrm{~Hz}, 1 \mathrm{H}), 5.08(\mathrm{~m}, 2 \mathrm{H}), 4.85\left(\mathrm{~A}\right.$ of $\left.\mathrm{AB}, J_{A B}=5.9 \mathrm{~Hz}, 1 \mathrm{H}\right), 4.78\left(\mathrm{~B}\right.$ of $\mathrm{AB}, J_{A B}=$ $5.8 \mathrm{~Hz}, 1 \mathrm{H}), 4.35\left(\mathrm{~A}\right.$ of $\left.\mathrm{AB}, J_{A B}=11.2 \mathrm{~Hz}, 1 \mathrm{H}\right), 4.18(\mathrm{dd}, J=9.5,2.5 \mathrm{~Hz}, 1 \mathrm{H}), 3.90(\mathrm{~B}$ of AB, $\left.J_{A B}=11.2 \mathrm{~Hz}, 1 \mathrm{H}\right), 3.88(\mathrm{~d}, J=3.2 \mathrm{~Hz}, 1 \mathrm{H}), 2.47(\mathrm{~m}, 1 \mathrm{H}), 2.28(\mathrm{ddd}, J=14.9,9.3,9.3 \mathrm{~Hz}, 1$ H), $1.78(\mathrm{~m}, 1 \mathrm{H}), 1.68(\mathrm{~m}, 1 \mathrm{H}), 1.43(\mathrm{~m}, 1 \mathrm{H}), 1.38(\mathrm{~s}, 3 \mathrm{H}), 1.33-1.25(\mathrm{~m}, 6 \mathrm{H}), 1.21(\mathrm{~s}, 9 \mathrm{H})$, $0.96(\mathrm{t}, J=7.9 \mathrm{~Hz}, 9 \mathrm{H}), 0.88(\mathrm{t}, J=6.9 \mathrm{~Hz}, 3 \mathrm{H}), 0.61(\mathrm{q}, J=8.3 \mathrm{~Hz}, 6 \mathrm{H}) ;{ }^{13} \mathrm{C} \mathrm{NMR}(125 \mathrm{MHz}$, $\left.\mathrm{CDCl}_{3}\right) \delta 178.2,137.9,116.4,90.2,80.8,75.3,73.7,67.8,52.3,38.9,33.5,31.7,30.9,27.2(3)$, 26.2, 22.6, 19.4, 14.0, 7.0 (3), 5.1 (3); FT-IR (thin film) 3078, 2957, 2878, 1736, 1459, 1414, 
1378, 1283, 1238, 1147, 1073, 1004, 837, $741 \mathrm{~cm}^{-1}$; HRMS $\left(\mathrm{CI} / \mathrm{NH}_{3}\right)$ calcd for $\left[\mathrm{C}_{26} \mathrm{H}_{50} \mathrm{O}_{5} \mathrm{Si}+\mathrm{H}\right]^{+}$ 471.3514, found 471.3506 m/z; Anal. calcd for $\mathrm{C}_{26} \mathrm{H}_{50} \mathrm{O}_{5} \mathrm{Si}$ : C, 66.34; $\mathrm{H}, 10.71$; found $\mathrm{C}, 66.40$; $\mathrm{H}, 10.85$.
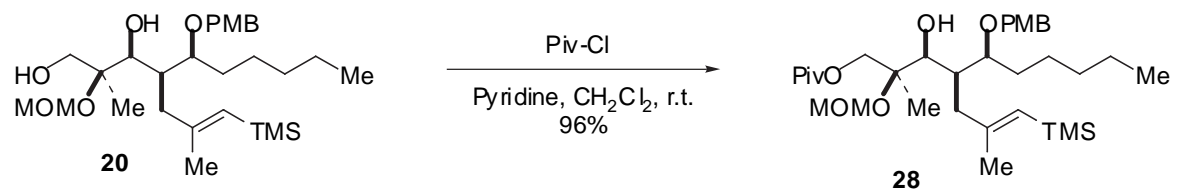

$(2 S, 3 S, 4 R, 5 S)-1-T r i m e t h y l a c e t o x y-3-h y d r o x y-5-p$-methoxybenzyloxy-2-

methoxymethyleneoxy-2-methyl-4-(E-2'-methyl-3' ${ }^{\prime}$-trimethylsilylprop-2' ${ }^{\prime}$-enyl $)$ decane $(28)$. A solution of $1.16 \mathrm{~g}(2.30 \mathrm{mmol})$ of diol 20 in $10 \mathrm{~mL}$ of $\mathrm{CH}_{2} \mathrm{Cl}_{2}$ and $3 \mathrm{~mL}$ of dry pyridine was treated with $560 \mu \mathrm{L}(4.60 \mathrm{mmol})$ of pivaloyl chloride. The solution was stirred at room temperature for $7 \mathrm{~h}$. The reaction mixture was diluted with $100 \mathrm{~mL}$ of $\mathrm{Et}_{2} \mathrm{O}$, washed with $1 \mathrm{~N}$ $\mathrm{KHSO}_{4}(4 \times 15 \mathrm{~mL}) \mathrm{NaHCO}_{3}(1 \times 25 \mathrm{~mL})$, dried over $\mathrm{MgSO}_{4}$, and concentrated. Purification of the crude product by flash chromatography $\left(25 \mathrm{~g} \mathrm{SiO}_{2}, 10 \%\right.$ EtOAc/hexanes) gave $1.30 \mathrm{~g}(96 \%)$ of pivaloate 28 as a yellow oil: $[\alpha]^{24}-33.7^{\circ}\left(c=1.34, \mathrm{CHCl}_{3}\right) ;{ }^{1} \mathrm{H}$ NMR $\left(500 \mathrm{MHz}, \mathrm{CDCl}_{3}\right) \delta$ $7.22(\mathrm{~d}, J=8.6 \mathrm{~Hz}, 2 \mathrm{H}), 6.84(\mathrm{~d}, J=8.6 \mathrm{~Hz}, 2 \mathrm{H}), 5.24(\mathrm{~s}, 1 \mathrm{H}), 4.81\left(\mathrm{~A}\right.$ of $\mathrm{AB}, J_{A B}=7.1 \mathrm{~Hz}, 1$ $\mathrm{H}), 4.75\left(\mathrm{~B}\right.$ of $\left.\mathrm{AB}, J_{A B}=7.1 \mathrm{~Hz}, 1 \mathrm{H}\right), 4.45\left(\mathrm{~A}\right.$ of $\left.\mathrm{AB}, J_{A B}=11.2 \mathrm{~Hz}, 1 \mathrm{H}\right), 4.27\left(\mathrm{~A}\right.$ of $\mathrm{AB}, J_{A B}=$ $11.5 \mathrm{~Hz}, 1 \mathrm{H}), 4.24\left(\mathrm{~B}\right.$ of $\left.\mathrm{AB}, J_{A B}=11.2 \mathrm{~Hz}, 1 \mathrm{H}\right), 4.16\left(\mathrm{~B}\right.$ of $\left.\mathrm{AB}, J_{A B}=11.5 \mathrm{~Hz}, 1 \mathrm{H}\right), 3.87(\mathrm{~d}, J$ $=6.6 \mathrm{~Hz}, 1 \mathrm{H}), 3.79(\mathrm{~s}, 3 \mathrm{H}), 3.38(\mathrm{~s}, 3 \mathrm{H}), 3.31(\mathrm{ddd}, J=9.8,2.7,2.6 \mathrm{~Hz}, 1 \mathrm{H}), 2.62(\mathrm{~d}, J=6.6$ $\mathrm{Hz}, 1 \mathrm{H}), 2.45\left(\mathrm{~A}\right.$ of ABX, $\left.J_{A B}=14.4, J_{A X}=2.0 \mathrm{~Hz}, 1 \mathrm{H}\right), 2.29(\mathrm{ddd}, J=11.2,3.2,2.9 \mathrm{~Hz}, 1 \mathrm{H})$, $2.11\left(\mathrm{~B}\right.$ of $\left.\mathrm{ABX}, J_{A B}=14.2, J_{B X}=11.2 \mathrm{~Hz}, 1 \mathrm{H}\right), 1.80(\mathrm{~s}, 3 \mathrm{H}), 1.60-1.52(\mathrm{~m}, 1 \mathrm{H}), 1.51-1.38$ $(\mathrm{m}, 2 \mathrm{H}), 1.28(\mathrm{~s}, 3 \mathrm{H}), 1.28-1.20(\mathrm{~m}, 2 \mathrm{H}), 1.20(\mathrm{~s}, 9 \mathrm{H}), 1.16-1.10(\mathrm{~m}, 3 \mathrm{H}), 0.84(\mathrm{t}, J=7.1$ $\mathrm{Hz}, 3 \mathrm{H}), 0.09$ (s, $9 \mathrm{H}) ;{ }^{13} \mathrm{C} \mathrm{NMR}\left(125 \mathrm{MHz}, \mathrm{CDCl}_{3}\right) \delta 178.1,159.1,153.1,130.8,129.6,125.7$, 113.7, 91.6, 80.9, 79.3, 72.0, 70.7, 66.9, 55.7, 55.3, 38.8, 38.4, 36.6, 31.6, 29.4, 27.2 , 26.2, 22.8, 21.6, 17.6, 14.1, 0.03; FT-IR (neat) 3520, 2956, 1732, 1614, 1514, 1481, 1464, 1398, 1284, 
1248, 1148, 1080, 1036, 921, 870, $837 \mathrm{~cm}^{-1}$;HRMS (FAB) calcd for $\left[\mathrm{C}_{33} \mathrm{H}_{58} \mathrm{O}_{7} \mathrm{Si}+\mathrm{Na}\right]^{+} 617.3849$, found $617.3853 \mathrm{~m} / \mathrm{z}$.

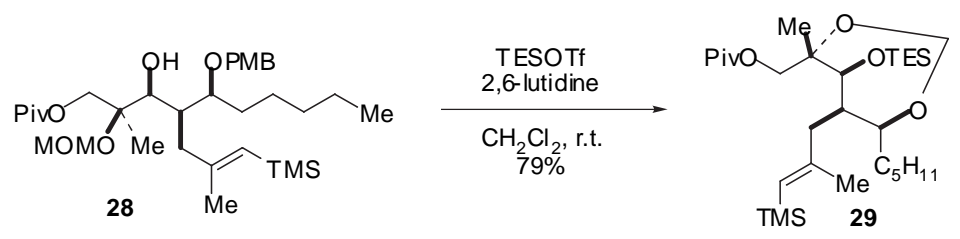

$(2 S, 3 S, 4 R, 5 S)-2,5-O$-Methylidene-2-methyl-4-(E-2'-methyl-3'-trimethylsilylprop-2' enyl)-3-[(triethylsilyl)oxy]-1-trimethylacetoxy-decane (29). A $50 \mathrm{~mL}$ round-bottom flask with septum was charged with $815 \mathrm{mg}(1.37 \mathrm{mmol})$ of pivaloate ester 28 and $16 \mathrm{~mL}$ of $\mathrm{CH}_{2} \mathrm{Cl}_{2}$. The solution was treated sequentially with $1.28 \mathrm{~mL}(12.6 \mathrm{mmol})$ of 2,6-lutidine and $1.24 \mathrm{~mL}(5.50$ mmol) of TESOTf, and stirred at room temperature for $4 \mathrm{~h}$. After quenching the reaction with saturated aqueous $\mathrm{NaHCO}_{3}$ and separation of the layers, the aqueous layer was washed with $\mathrm{Et}_{2} \mathrm{O}$. The combined organic layers were washed with $1 \mathrm{~N} \mathrm{KHSO}_{4}$ and saturated aqueous $\mathrm{NaHCO}_{3}$, dried over $\mathrm{MgSO}_{4}$, and concentrated. Purification of the crude product by flash chromatography (30 g of $\mathrm{SiO}_{2}$, gradient $0.5 \%$ to $4 \%$ EtOAc/hexanes) gave $620 \mathrm{mg}(84 \%)$ of acetal 29 as a colorless oil which contained about $10 \%$ of an impurity that was carried through the next reaction: $[\alpha]_{\mathrm{D}}^{24}+11.6^{\circ}\left(c=1.17, \mathrm{CHCl}_{3}\right) ;{ }^{1} \mathrm{H} \mathrm{NMR}\left(500 \mathrm{MHz}, \mathrm{CDCl}_{3}\right) \delta 5.29(\mathrm{~s}, 1 \mathrm{H})$, $4.84\left(\mathrm{~A}\right.$ of $\left.\mathrm{AB}, J_{A B}=6.1 \mathrm{~Hz}, 1 \mathrm{H}\right), 4.77\left(\mathrm{~B}\right.$ of $\left.\mathrm{AB}, J_{A B}=6.1 \mathrm{~Hz}, 1 \mathrm{H}\right), 4.36\left(\mathrm{~A}\right.$ of $\mathrm{AB}, J_{A B}=11.5$ $\mathrm{Hz}, 1 \mathrm{H}), 4.19(\mathrm{dd}, J=9.5,2.4 \mathrm{~Hz}, 1 \mathrm{H}), 3.90\left(\mathrm{~B}\right.$ of AB, $\left.J_{A B}=11.2 \mathrm{~Hz}, 1 \mathrm{H}\right), 3.89(\mathrm{~d}, J=3.2 \mathrm{~Hz}$, $1 \mathrm{H}), 2.38\left(\mathrm{~A}\right.$ of $\left.\mathrm{ABX}, J_{A B}=15.4, J_{A X}=4.0 \mathrm{~Hz}, 1 \mathrm{H}\right), 2.28\left(\mathrm{~B}\right.$ of $\mathrm{ABX}, J_{A B}=15.4, J_{B X}=9.0 \mathrm{~Hz}$, $1 \mathrm{H}), 1.92-1.87(\mathrm{~m}, 1 \mathrm{H}), 1.81(\mathrm{~s}, 3 \mathrm{H}), 1.72-1.63(\mathrm{~m}, 1 \mathrm{H}), 1.48-1.36(\mathrm{~m}, 1 \mathrm{H}), 1.37$ (s, 3 H), 1.35-1.20 (m, $6 \mathrm{H}), 1.20(\mathrm{~s}, 3 \mathrm{H}), 0.96(\mathrm{t}, J=8.1 \mathrm{~Hz}, 9 \mathrm{H}), 0.87(\mathrm{t}, J=6.8 \mathrm{~Hz}, 3 \mathrm{H}), 0.65-$ $0.58(\mathrm{~m}, 6 \mathrm{H}), 0.10(\mathrm{~s}, 9 \mathrm{H}) ;{ }^{13} \mathrm{CNMR}\left(125 \mathrm{MHz}, \mathrm{CDCl}_{3}\right) \delta 178.2,153.5,125.3,90.2,80.9,75.5$, 74.2, 67.7, 49.9, 38.9, 38.7, 33.4, 31.8, 27.2, 26.3, 22.6, 22.1, 20.5, 14.0, 6.95, 5.09, -0.07; FT-IR (thin film) 2957, 1732, 1614, 1480, 1463, 1378, 1283, 1128, 1065, 838, 769, $743 \mathrm{~cm}^{-1}$; HRMS (FAB) calcd for $\left[\mathrm{C}_{30} \mathrm{H}_{60} \mathrm{O}_{5} \mathrm{Si}_{2}+\mathrm{Na}\right]^{+} 579.3877$, found $579.3888 \mathrm{~m} / \mathrm{z}$. 


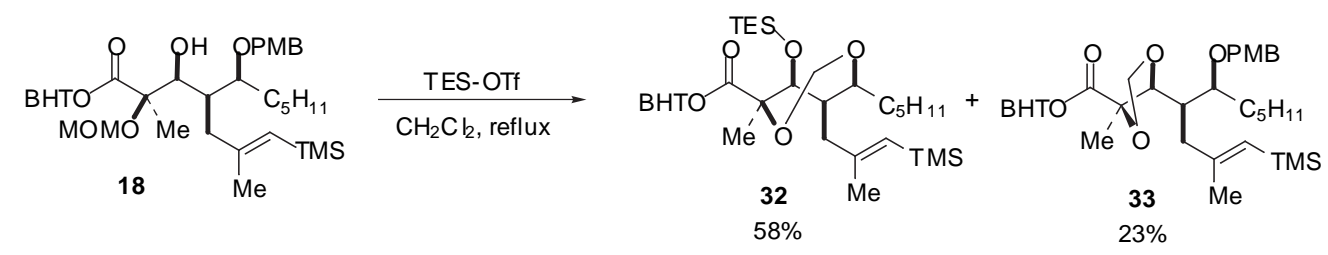

\section{Synthesis of $\quad(2 S, 3 S, 4 R, 5 S)-2,5-O$-Methylidene-2-methyl-4-(E-2'-methyl-3'-} trimethylsilylprop-2'-enyl)-3-[(triethylsilyl)oxy]-1-(2',6'-Di-t-butyl-4' -

methylphenylcarboxy)-decane (32). A flame-dried $1 \mathrm{~mL}$ Wheaton vial was charged with a solution $23 \mathrm{mg}(0.032 \mathrm{mmol})$ of ester 18 and $300 \mu \mathrm{L}$ of $\mathrm{CH}_{2} \mathrm{Cl}_{2}$. The solution was treated sequentially with $38 \mu \mathrm{L}(0.32 \mathrm{mmol})$ of 2,6-lutidine and $64 \mu \mathrm{L}(0.28 \mathrm{mmol})$ of TESOTf, and heated to reflux for $24 \mathrm{~h}$. After quenching the reaction with saturated aqueous $\mathrm{NaHCO}_{3}$ and separation of the layers, the aqueous layer was washed with $\mathrm{Et}_{2} \mathrm{O}$. The combined organic layers were washed with $1 \mathrm{~N} \mathrm{KHSO}_{4}$ and saturated aqueous $\mathrm{NaHCO}_{3}$, dried over $\mathrm{MgSO}_{4}$, and concentrated. Purification of the crude product by prep-plate chromatography $(250 \mu \mathrm{m}, 5 \%$ EtOAc/hexanes) gave $12.3 \mathrm{mg}(58 \%)$ of acetal 32, and $4.9 \mathrm{mg}$ of acetal $\mathbf{3 3}(23 \%)$ :

Data for 32: ${ }^{1} \mathrm{H}$ NMR $\left(500 \mathrm{MHz}, \mathrm{CDCl}_{3}\right) \delta 7.10(\mathrm{~s}, 2 \mathrm{H}), 5.33,(\mathrm{~s}, 1 \mathrm{H}), 5.09$, (A of AB, $\left.J_{A B}=6.1 \mathrm{~Hz}, 1 \mathrm{H}\right), 5.02,\left(\mathrm{~A}\right.$ of $\left.\mathrm{AB}, J_{A B}=5.1 \mathrm{~Hz}, 1 \mathrm{H}\right), 4.25,(\mathrm{~d}, \mathrm{~J}=3.4,1 \mathrm{H}), 4.21,(\mathrm{~d}, \mathrm{~J}=9.3 \mathrm{~Hz}$, 1H) 2.42- 2.36, (m, 1H), 2.34-2.26, (m, 1H), $2.31(\mathrm{~s}, 3 \mathrm{H}), 1.70-1.60,(\mathrm{~m}, 1 \mathrm{H}), 1.52-1.42$, (m, 1H), 1.36, (s, 9H), $1.36-1.24,(\mathrm{~m}, 6 \mathrm{H}), 1.33$ (s, 9H), 0.92, (app. q, J = 8.1 Hz, 9H), $0.70-0.50$, $(\mathrm{m}, 6 \mathrm{H}), 0.10(\mathrm{~s}, 9 \mathrm{H}) ;{ }^{13} \mathrm{C} \mathrm{NMR}\left(125 \mathrm{MHz}, \mathrm{CDCl}_{3}\right) \delta 171.2,153.4,146.9,142.9,142.1,134.1$, $126.9,126.8,125.5,90.2,84.7,76.6,74.5,40.0,35.33,35.32,31.8,31.5,31.4,26.3,22.6,22.0$, 21.7, 21.4, 14.0, 7.1, 5.2, -0.08; HRMS (FAB) calcd for $\left[\mathrm{C}_{40} \mathrm{H}_{72} \mathrm{O}_{5} \mathrm{Si}_{2}+\mathrm{Na}\right]^{+} 711.4816$, found $711.4830 \mathrm{~m} / \mathrm{z}$.

Data for 33: ${ }^{1} \mathrm{H} \mathrm{NMR}\left(500 \mathrm{MHz}, \mathrm{CDCl}_{3}\right) \delta 7.19,(\mathrm{~d}, \mathrm{~J}=8.4 \mathrm{~Hz}, 2 \mathrm{H}), 7.12,(\mathrm{~s}, 1 \mathrm{H}), 6.81$, $(\mathrm{d}, \mathrm{J}=8.8 \mathrm{~Hz}, 2 \mathrm{H}), 5.25,(\mathrm{~s}, 1 \mathrm{H}), 5.22$, (dd, J = 6.6, 1.1 Hz, 2H), 4.82, (s, 1H), 4.42, (A of AB, $\left.J_{A B}=11.7 \mathrm{~Hz}, 1 \mathrm{H}\right) 4.37\left(\mathrm{~B}\right.$ of $\left.\mathrm{AB}, J_{A B}=11.7 \mathrm{~Hz}, 1 \mathrm{H}\right), 3.78,(\mathrm{~s}, 3 \mathrm{H}), 3.33$ (app.dt, J = 9.5, 2.6 $\mathrm{Hz}, 1 \mathrm{H}), 2.42-2.33,(\mathrm{~m}, 1 \mathrm{H}), 2.33,(\mathrm{~s}, 3 \mathrm{H}), 2.24-2.15,(\mathrm{~m}, 1 \mathrm{H}), 1.75,(\mathrm{~s}, 3 \mathrm{H}), 1.68,(\mathrm{~s}, 3 \mathrm{H}), 1.60$ 
$-1.40,(\mathrm{~m}, 3 \mathrm{H}), 1.32(\mathrm{~s}, 9 \mathrm{H}), 1.30(\mathrm{~s}, 9 \mathrm{H}), 1.30-1.20,(\mathrm{~m}, 2 \mathrm{H}), 1.20-1.12,(\mathrm{~m}, 3 \mathrm{H}), 0.85$, (t, J $=7.3 \mathrm{~Hz}, 3 \mathrm{H}), 0.10(\mathrm{~s}, 9 \mathrm{H}) ;{ }^{13} \mathrm{CNMR}\left(125 \mathrm{MHz}, \mathrm{CDCl}_{3}\right) \delta 173.1,159.0,152.1,146.4,142.5$, 141.9, 134.7, 131.1, 129.5, 127.1, 127.0, 126.2, 113.6, 95.5, 83.5, 78.1, 78.0, 70.7, 55.2, 38.7, 37.5, 35.3, 31.7, 31.4, 30.0, 26.2, 22.8, 21.4, 20.1, 14.1, -0.01; FT-IR (thin film) 2956, 1748, $1615,1514,1456,1418,1366,1249,1180,1098,838,736,699 \mathrm{~cm}^{-1}$; HRMS (FAB) calcd for $\left[\mathrm{C}_{42} \mathrm{H}_{66} \mathrm{O}_{6} \mathrm{Si}+\mathrm{Na}\right]^{+} 717.4526$, found $717.4529 \mathrm{~m} / z$.
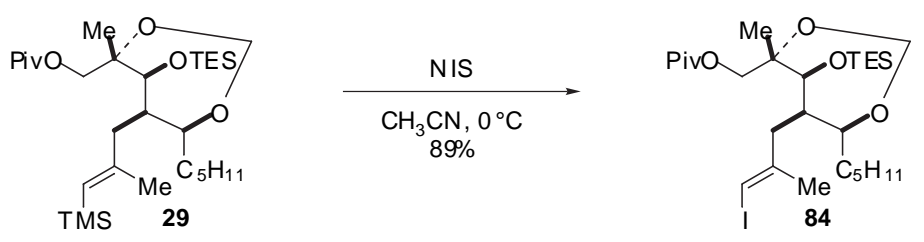

\section{(2S,3S,4R,5S)-2,5-O-Methylidene-2-methyl-4-(E-2'-methyl-3'-iodoprop-2'-enyl)-3-}

[(triethylsilyl)oxy]-1-trimethylacetoxy-decane (84). A $100 \mathrm{~mL}$ round bottom flask was charged with a solution of $600 \mathrm{mg}(1.11 \mathrm{mmol})$ of vinylsilane 29 in dry $\mathrm{CH}_{3} \mathrm{CN}(30 \mathrm{~mL})$ and cooled in an ice bath. $N$-iodosuccinimide (374 $\mathrm{mg}, 1.66 \mathrm{mmol}$ ) was added in a single portion and the solution was stirred at room temperature for $1 \mathrm{~h}$. An additional $115 \mathrm{mg}(0.50 \mathrm{mmol})$ of $\mathrm{N}$-iodosuccinimide was added and the reaction was stirred for $4 \mathrm{~h}$ until complete. The reaction mixture was diluted with $100 \mathrm{~mL}$ of $\mathrm{Et}_{2} \mathrm{O}$ and washed with $\mathrm{Na}_{2} \mathrm{~S}_{2} \mathrm{O}_{3}(1 \times 20 \mathrm{~mL})$. The aqueous layer was washed with $10 \mathrm{~mL}$ of $\mathrm{Et}_{2} \mathrm{O}$. The combined organic layers were washed with saturated $\mathrm{NaCl}$ solution, dried over $\mathrm{MgSO}_{4}$, and concentrated. The crude oily solid was suspended in hexanes and filtered to remove the solid succinimide and the filtrate concentrated to provide 675 mg (99\%) of vinyl iodide 84 as a clear oil that was sufficiently pure for the next reaction: ${ }^{1} \mathrm{H}$ $\operatorname{NMR}\left(500 \mathrm{MHz}, \mathrm{CDCl}_{3}\right) \delta 5.98(\mathrm{~s}, 1 \mathrm{H}), 4.84\left(\mathrm{~A}\right.$ of $\left.\mathrm{AB}, J_{A B}=5.9 \mathrm{~Hz}, 1 \mathrm{H}\right), 4.76\left(\mathrm{~B}\right.$ of $\mathrm{AB}, J_{A B}=$ $5.9 \mathrm{~Hz}, 1 \mathrm{H}), 4.35\left(\mathrm{~A}\right.$ of $\left.\mathrm{AB}, J_{A B}=11.2 \mathrm{~Hz}, 1 \mathrm{H}\right), 4.20(\mathrm{dd}, J=8.8,1.8 \mathrm{~Hz}, 1 \mathrm{H}), 3.92(\mathrm{~B}$ of AB, $\left.J_{A B}=11.2 \mathrm{~Hz}, 1 \mathrm{H}\right), 3.78(\mathrm{~d}, J=2.9 \mathrm{~Hz}, 1 \mathrm{H}), 2.55-2.42,(\mathrm{~m}, 2 \mathrm{H}), 1.88(\mathrm{~s}, 3 \mathrm{H}), 1.84,(\mathrm{~m}, 1 \mathrm{H})$, $1.68(\mathrm{~m}, 1 \mathrm{H}), 1.46-1.38(\mathrm{~m}, 1 \mathrm{H}), 1.39$ (s, $3 \mathrm{H}), 1.36$ - 1.22 (m, $6 \mathrm{H}), 1.20$ (s, $9 \mathrm{H}), 1.10$ 0.94, (m, 9H), $0.88(\mathrm{t}, J=6.8 \mathrm{~Hz}, 3 \mathrm{H}), 0.65-0.58(\mathrm{~m}, 6 \mathrm{H}) ;{ }^{13} \mathrm{C} \mathrm{NMR}\left(125 \mathrm{MHz}, \mathrm{CDCl}_{3}\right) \delta$ 
178.1, 146.4, 90.2, 80.8, 76.5, 75.3, 73.7, 67.6, 50.0, 38.9, 36.4, 33.4, 31.7, 27.2, 26.2, 24.2, 22.6, 20.2, 14.0, 7.0, 5.1; FT-IR (neat) 3449(br), 2957, 2878, 1732, 1480, 1462, 1378, 1282, 1128 , $1063,1009,838,743,685 \mathrm{~cm}^{-1}$; HRMS (FAB) calcd for $\left[\mathrm{C}_{27} \mathrm{H}_{51} \mathrm{IO}_{5} \mathrm{Si}_{2}+\mathrm{Na}\right]^{+} 633.2448$, found $633.2457 \mathrm{~m} / \mathrm{z}$.
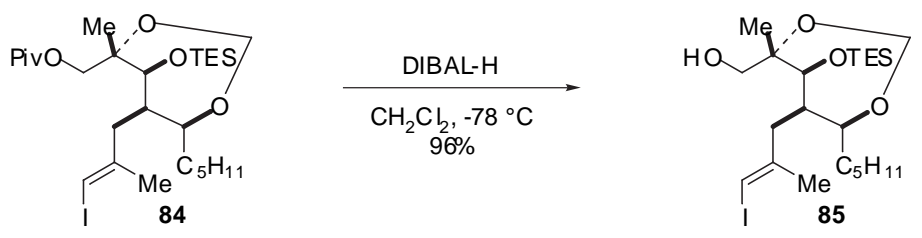

\section{$(2 S, 3 S, 4 R, 5 S)-2,5-O$-Methylidene-2-methyl-4-( $E$-2'-methyl-3'-iodoprop-2'-enyl)-3-}

[(triethylsilyl)oxy]-decan-1-ol (85). A solution of $660 \mathrm{mg}(0.067 \mathrm{mmol})$ of the pivaloate ester 84 in $20 \mathrm{~mL}$ of dry $\mathrm{CH}_{2} \mathrm{Cl}_{2}$ was cooled in a dry ice/acetone bath and treated dropwise with 2.78 $\mathrm{mL}\left(2.78 \mathrm{mmol}, 1 \mathrm{M}\right.$ in hexanes) of DIBAL-H. The reaction mixture was stirred at $-78{ }^{\circ} \mathrm{C}$ for $45 \mathrm{~min}$ and then quenched with saturated aqueous potassium sodium tartrate solution $(15 \mathrm{~mL})$ and diluted with $\mathrm{Et}_{2} \mathrm{O}(50 \mathrm{~mL})$. The biphasic mixture was stirred for $12 \mathrm{~h}$, the layers separated, the aqueous reextracted with $\mathrm{Et}_{2} \mathrm{O}(2 \times 15 \mathrm{~mL})$. The combined organic layers were washed saturated $\mathrm{NaCl}$ solution, dried over $\mathrm{MgSO}_{4}$, and concentrated. Purification of the crude product by flash chromatography (30 $\mathrm{g}$ of $\mathrm{SiO}_{2}, 20 \%$ to $25 \%$ EtOAc/hexanes) gave $518 \mathrm{mg}$ (91\%) slightly impure alcohol. HPLC purification (21 mm column; 30\% EtOAc/hexanes) of this material furnished $480 \mathrm{mg}$ (85\%) of pure neopentyl alcohol 85 as a light yellow oil: $[\alpha]_{\mathrm{D}}^{25}$ $+14.2^{\circ}\left(c=0.77, \mathrm{CHCl}_{3}\right) ;{ }^{1} \mathrm{H} \mathrm{NMR}\left(500 \mathrm{MHz}, \mathrm{CDCl}_{3}\right) \delta 5.99(\mathrm{~s}, 1 \mathrm{H}), 4.89\left(\mathrm{~A}\right.$ of $\mathrm{AB}, J_{A B}=5.9$ $\mathrm{Hz}, 1 \mathrm{H}), 4.87\left(\mathrm{~B}\right.$ of AB, $\left.J_{A B}=6.1 \mathrm{~Hz}, 1 \mathrm{H}\right), 4.18(\mathrm{dd}, J=9.8,2.4 \mathrm{~Hz}, 1 \mathrm{H}), 3.86(\mathrm{dd}, J=11.2$, $2.2 \mathrm{~Hz}, 1 \mathrm{H}), 3.77(\mathrm{~d}, J=2.9 \mathrm{~Hz}, 1 \mathrm{H}), 3.37$ (dd, $J=10.5,10.5 \mathrm{~Hz}, 1 \mathrm{H}), 2.51(\mathrm{dd}, J=14.8,4.3$ Hz, $1 \mathrm{H}), 2.45$ (dd, $J=14.9,8.8 \mathrm{~Hz}, 1 \mathrm{H}), 1.95$ (dd, $J=9.9,2.8 \mathrm{~Hz}, 1 \mathrm{H}), 1.87$ (s, $3 \mathrm{H}), 1.84(\mathrm{~m}$, $1 \mathrm{H}), 1.67(\mathrm{~m}, 1 \mathrm{H}), 1.41(\mathrm{~m}, 1 \mathrm{H}), 1.38(\mathrm{~s}, 3 \mathrm{H}), 1.32-1.24(\mathrm{~m}, 6 \mathrm{H}), 0.96(\mathrm{t}, J=8.0 \mathrm{~Hz}, 9 \mathrm{H})$, $0.88(\mathrm{t}, J=6.8 \mathrm{~Hz}, 3 \mathrm{H}), 0.60(\mathrm{q}, J=7.7 \mathrm{~Hz}, 3 \mathrm{H}), 0.59(\mathrm{q}, J=8.1 \mathrm{~Hz}, 3 \mathrm{H}) ;{ }^{13} \mathrm{CNMR}(125 \mathrm{MHz}$, 
$\left.\mathrm{CDCl}_{3}\right) \delta 146.5,90.3,81.9,76.7,76.6,73.8,68.3,50.0,36.5,33.3,31.7,26.2,24.3,22.3,19.9$, 14.0, 6.9 (3), 5.0 (3); FT-IR (thin film) 3468, 3054, 2955, 2932, 2876, 1459, 1413, 1377, 1271, 1237, 1125, 1066, 836, 737, $725 \mathrm{~cm}^{-1}$; HRMS (FAB) calcd for $\left[\mathrm{C}_{22} \mathrm{H}_{43} \mathrm{IO}_{4} \mathrm{Si}+\mathrm{Na}\right]^{+} 549.1875$, found $549.1895 \mathrm{~m} / \mathrm{z}$.
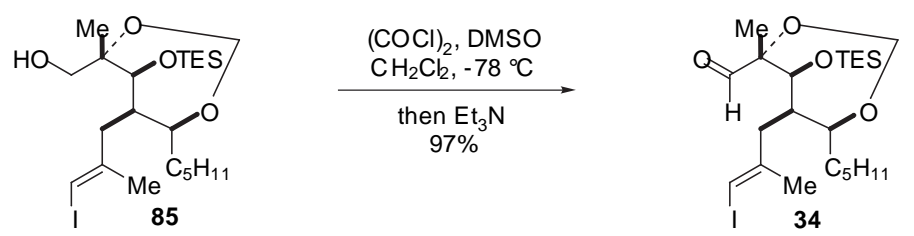

\section{$(2 S, 3 S, 4 R, 5 S)-2,5-O$-Methylidene-2-methyl-4-(E-2'-methyl-3'-iodoprop-2'-enyl)-3-}

[(triethylsilyl)oxy]-decan-1-al (34). A solution of $60 \mu \mathrm{L}(0.84 \mathrm{mmol})$ of anhydrous DMSO in $4.0 \mathrm{~mL}$ of $\mathrm{CH}_{2} \mathrm{Cl}_{2}$ was cooled in a dry ice/acetone bath, treated with $55 \mu \mathrm{L}(0.63 \mathrm{mmol})$ of oxalyl chloride, and stirred for $15 \mathrm{~min}$ A solution of $222 \mathrm{mg}(0.42 \mathrm{mmol})$ of the neopentyl alcohol 85 in $0.5 \mathrm{~mL}$ of $\mathrm{CH}_{2} \mathrm{Cl}_{2}$ was added dropwise to the reaction mixture followed by $0.5 \mathrm{~mL}$ rinse, and the resulting solution was stirred at $-78{ }^{\circ} \mathrm{C}$ for $20 \min \mathrm{Et}_{3} \mathrm{~N}(55 \mu \mathrm{L}, 0.388 \mathrm{mmol})$ was added, the cold bath was removed, and the cloudy suspension was allowed to warm to $0{ }^{\circ} \mathrm{C}$. After dilution of the mixture with pentanes $(30 \mathrm{~mL})$, the reaction was filtered to remove the $\mathrm{Et}_{3} \mathrm{~N}$ salts and the filtrate was washed with $\mathrm{H}_{2} \mathrm{O}(2 \times 5 \mathrm{~mL})$. The combined organics were washed with saturated aqueous $\mathrm{NaHCO}_{3}$, dried over $\mathrm{MgSO}_{4}$, and concentrated. The crude material was passed through a short pad of $\mathrm{SiO}_{2}$ with $30 \% \mathrm{EtOAc/hexanes} \mathrm{to} \mathrm{provide} 215 \mathrm{mg}$ (97\%) of aldehyde 34 as a yellow oil: ${ }^{1} \mathrm{H}$ NMR $\left(500 \mathrm{MHz}, \mathrm{CDCl}_{3}\right) \delta 9.52(\mathrm{~s}, 1 \mathrm{H}), 6.01(\mathrm{~s}, 1 \mathrm{H}), 5.00\left(\mathrm{~A}\right.$ of $\mathrm{AB}, J_{A B}=5.8$ $\mathrm{Hz}, 1 \mathrm{H}), 4.94\left(\mathrm{~B}\right.$ of $\left.\mathrm{AB}, J_{A B}=5.8 \mathrm{~Hz}, 1 \mathrm{H}\right), 4.25(\mathrm{dd}, J=9.6,2.6 \mathrm{~Hz}, 1 \mathrm{H}), 4.07(\mathrm{~d}, J=2.8 \mathrm{~Hz}, 1$ H), $2.51(\mathrm{dd}, J=14.5,3.8 \mathrm{~Hz}, 1 \mathrm{H}), 2.36(\mathrm{dd}, J=14.9,9.5 \mathrm{~Hz}, 1 \mathrm{H}), 1.87(\mathrm{~s}, 3 \mathrm{H}), 1.80(\mathrm{~m}, 1 \mathrm{H})$, $1.69(\mathrm{~m}, 1 \mathrm{H}), 1.43(\mathrm{~m}, 1 \mathrm{H}), 1.37(\mathrm{~s}, 3 \mathrm{H}), 1.31-1.25(\mathrm{~m}, 6 \mathrm{H}), 0.92(\mathrm{t}, J=7.9 \mathrm{~Hz}, 9 \mathrm{H}), 0.89$ (t, $J=7.0 \mathrm{~Hz}, 3 \mathrm{H}), 0.55(\mathrm{q}, J=7.6 \mathrm{~Hz}, 3 \mathrm{H}), 0.54(\mathrm{q}, J=8.2 \mathrm{~Hz}, 3 \mathrm{H}) ;{ }^{13} \mathrm{CNMR}\left(125 \mathrm{MHz}, \mathrm{CDCl}_{3}\right)$

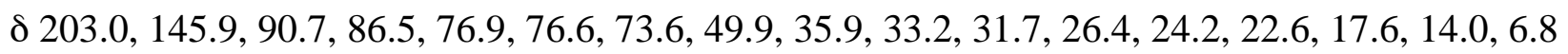


(3), 5.0 (3); FT-IR (thin film) 2955, 2933, 2877, 1740, 1458, 1413, 1375, 1271, 1138, 1126, 1062, 1008, $726 \mathrm{~cm}^{-1}$; HRMS (FAB) calcd for $\left[\mathrm{C}_{22} \mathrm{H}_{41} \mathrm{IO}_{4} \mathrm{Si}+\mathrm{Na}\right]^{+} 547.1717$, found $547.1716 \mathrm{~m} / z$.
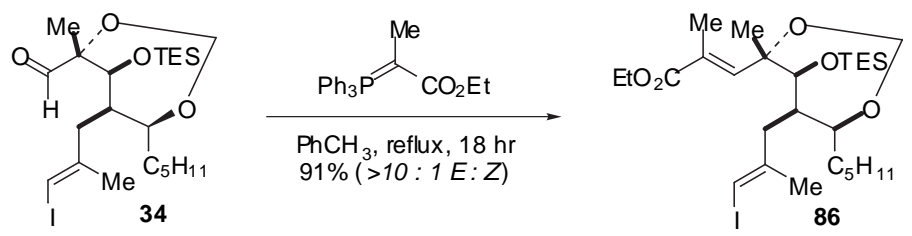

\section{Ethyl-(4S,5S,6R,7S)-2,4-dimethyl-4,7-O-methylidene-6-(E-2'-methyl-3' -iodoprop-2'-}

enyl)-5-[(triethylsilyl)oxy]-dodec-2-enoate (86). A $25 \mathrm{~mL}$ round bottom flask fitted with a cold-finger condensor was charged with $215 \mathrm{mg}(0.41 \mathrm{mmol})$ of aldehyde 34 [pre-dried by coevaporation from $\mathrm{PhH}(2 \times)]$ and $10 \mathrm{~mL}$ of toluene. Carbethoxyethylidenetriphenylphosporane (148 $\mathrm{mg}, 3.70 \mathrm{mmol}$ ) was added in a single portion, and the resulting yellow suspension was heated to vigorous reflux for $18 \mathrm{~h}$. After being cooled to room temperature, the reaction was diluted with hexanes, filtered and concentrated to remove $\mathrm{Ph}_{3} \mathrm{PO}$ and unreacted carbethoxyethylidenetriphenylphosporane. The filtrate was concentrated and the preceding process repeated two more times to remove the majority of $\mathrm{Ph}_{3} \mathrm{PO}$ and unreacted carbethoxyethylidenetriphenylphosporane. The residue was purified by flash chromatography (15 $\mathrm{g}$ of $\mathrm{SiO}_{2}, 5 \%$ EtOAc/hexanes) to give $245 \mathrm{mg}(99 \%)$ of $\mathbf{8 6}$ as a 10:1 mixture of $E: Z$ olefin isomers. Spectral data for the $E$ olefin isomer: $[\alpha]_{\mathrm{D}}^{26}+1.3^{\circ}\left(c=1.50, \mathrm{CHCl}_{3}\right) ;{ }^{1} \mathrm{H} \mathrm{NMR}(500$ $\left.\mathrm{MHz}, \mathrm{CDCl}_{3}\right) \delta 7.01(\mathrm{~d}, J=1.5 \mathrm{~Hz}, 1 \mathrm{H}), 6.00(\mathrm{~s}, 1 \mathrm{H}), 4.91\left(\mathrm{~A}\right.$ of $\left.\mathrm{AB}, J_{A B}=6.6 \mathrm{~Hz}, 1 \mathrm{H}\right), 4.74$ $\left(\mathrm{B}\right.$ of $\left.\mathrm{AB}, J_{A B}=6.4 \mathrm{~Hz}, 1 \mathrm{H}\right), 4.19(\mathrm{q}, J=7.1 \mathrm{~Hz}, 2 \mathrm{H}), 4.08(\mathrm{dd}, J=9.5,2.9 \mathrm{~Hz}, 1 \mathrm{H}), 3.79(\mathrm{~d}, J$ $=3.4 \mathrm{~Hz}, 1 \mathrm{H}), 2.49(\mathrm{~m}, 2 \mathrm{H}), 1.96(\mathrm{~d}, J=1.2 \mathrm{~Hz}, 3 \mathrm{H}), 1.87(\mathrm{~d}, J=1.0 \mathrm{~Hz}, 3 \mathrm{H}), 1.86(\mathrm{~m}, 1 \mathrm{H})$, $1.66(\mathrm{~m}, 1 \mathrm{H}), 1.48(\mathrm{~s}, 3 \mathrm{H}), 1.42(\mathrm{~m}, 1 \mathrm{H}), 1.32-1.25(\mathrm{~m}, 6 \mathrm{H}), 1.30(\mathrm{t}, J=7.2 \mathrm{~Hz}, 3 \mathrm{H}), 0.95(\mathrm{t}, J$ $=8.0 \mathrm{~Hz}, 9 \mathrm{H}), 0.89(\mathrm{t}, J=6.8 \mathrm{~Hz}, 3 \mathrm{H}), 0.61(\mathrm{q}, J=7.7 \mathrm{~Hz}, 3 \mathrm{H}), 0.60(\mathrm{q}, J=8.0 \mathrm{~Hz}, 3 \mathrm{H}) ;{ }^{13} \mathrm{C}$ NMR (125 MHz, $\left.\mathrm{CDCl}_{3}\right) \delta$ 168.6, 146.5, 13.8, 128.3, 90.3, 83.4, 78.5, 76.5, 74.3, 60.7, 49.4, 37.1, 33.2, 31.7, 26.2, 24.2, 24.1, 22.6, 14.2, 14.0, 13.1, 7.0 (3), 5.1 (3); FT-IR (thin film) 3054, 
2955, 2933, 2876, 1712, 1458, 1376, 1250, 1168, 1061, 828, $744 \mathrm{~cm}^{-1}$; HRMS (FAB) calcd for $\left[\mathrm{C}_{27} \mathrm{H}_{49} \mathrm{IO}_{5} \mathrm{Si}+\mathrm{Na}\right]^{+}$631.2292, found 631.2320.
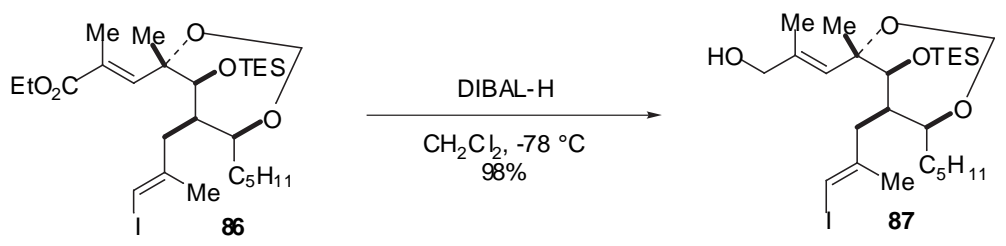

(4S,5S,6R,7S)-2,4-Dimethyl-4,7-O-methylidene-6-( $E$-2' -methyl-3'-iodoprop-2' -enyl)5-[(triethylsilyl)oxy]-dodec-2-en-1ol (87). A solution of $245 \mathrm{mg}(0.40 \mathrm{mmol})$ of the ester 86 in $3.0 \mathrm{~mL}$ of dry $\mathrm{CH}_{2} \mathrm{Cl}_{2}$ was cooled in a dry ice/acetone bath, treated dropwise with $1.0 \mathrm{~mL}$ (1.0 mmol, 1.0 $\mathrm{M}$ in hexanes) of DIBAL-H, and stirred at $-78{ }^{\circ} \mathrm{C}$ for $30 \mathrm{~min}$ After carefully quenching the reaction mixture with saturated aqueous potassium sodium tartrate solution and diluting with $\mathrm{Et}_{2} \mathrm{O}(25 \mathrm{~mL})$, the biphasic mixture was stirred vigorously at room temperature for $1 \mathrm{~h}$. The aqueous layer was separated and washed with $\mathrm{Et}_{2} \mathrm{O}(3 \times 10 \mathrm{~mL})$. The combined organic layers were washed with $\mathrm{H}_{2} \mathrm{O}$ and saturated $\mathrm{NaCl}$ solution, dried over $\mathrm{MgSO}_{4}$, and concentrated. Purification of the crude product by flash chromatography $\left(12 \mathrm{~g}\right.$ of $\mathrm{SiO}_{2}, 10 \%$ to $20 \%$ EtOAc/hexanes) gave $205 \mathrm{mg}(90 \%)$ of the allylic alcohol 87 as a slightly yellow oil: $[\alpha]^{25}$ $-14.1^{\circ}\left(c=1.18, \mathrm{CHCl}_{3}\right) ;{ }^{1} \mathrm{H} \mathrm{NMR}\left(500 \mathrm{MHz}, \mathrm{CDCl}_{3}\right) \delta 5.98(\mathrm{~d}, J=1.0 \mathrm{~Hz}, 1 \mathrm{H}), 5.79(\mathrm{~d}, J=$ $1.3 \mathrm{~Hz}, 1 \mathrm{H}), 4.88\left(\mathrm{~A}\right.$ of $\left.\mathrm{AB}, J_{A B}=6.4 \mathrm{~Hz}, 1 \mathrm{H}\right), 4.78\left(\mathrm{~B}\right.$ of $\left.\mathrm{AB}, J_{A B}=6.4 \mathrm{~Hz}, 1 \mathrm{H}\right), 4.01(\mathrm{~m}, 3$ $\mathrm{H}), 3.69(\mathrm{~d}, J=3.7 \mathrm{~Hz}, 1 \mathrm{H}), 2.52\left(\mathrm{~A}\right.$ of $\left.\mathrm{ABX}, J_{A B}=14.7 \mathrm{~Hz}, J_{A X}=8.1 \mathrm{~Hz}, 1 \mathrm{H}\right), 2.44(\mathrm{~B}$ of ABX, $\left.J_{A B}=14.7 \mathrm{~Hz}, J_{B X}=4.4 \mathrm{~Hz}, 1 \mathrm{H}\right), 1.87(\mathrm{~m}, 1 \mathrm{H}), 1.86(\mathrm{~d}, J=1.2 \mathrm{~Hz}, 3 \mathrm{H}), 1.77(\mathrm{~d}, J=1.2$ $\mathrm{Hz}, 3 \mathrm{H}), 1.65(\mathrm{~m}, 1 \mathrm{H}), 1.47(\mathrm{~s}, 3 \mathrm{H}), 1.38(\mathrm{~m}, 1 \mathrm{H}), 1.34-1.25(\mathrm{~m}, 6 \mathrm{H}), 0.96(\mathrm{t}, J=8.0 \mathrm{~Hz}, 9$ $\mathrm{H}), 0.89(\mathrm{t}, J=6.9 \mathrm{~Hz}, 3 \mathrm{H}), 0.60(\mathrm{q}, J=8.1 \mathrm{~Hz}, 6 \mathrm{H}) ;{ }^{13} \mathrm{C} \mathrm{NMR}\left(125 \mathrm{MHz}, \mathrm{CDCl}_{3}\right) \delta 146.7$, 136.4, 128.0, 89.8, 82.8, 78.9, 76.4, 74.3, 69.6, 49.1, 37.6, 32.8, 31.7, 26.2, 25.8, 24.0, 22.6, 14.5, 14.0, 7.0 (3), 5.2 (3); FT-IR (thin film) 3401, 3054, 2954, 2931, 2875, 1458, 1376, 1270, 1235 , 
1077, 1037, 1011, 815, $726 \mathrm{~cm}^{-1}$; HRMS (FAB) calcd for $\left[\mathrm{C}_{25} \mathrm{H}_{47} \mathrm{IO}_{4} \mathrm{Si}+\mathrm{Na}\right]^{+} 589.2186$, found $589.2200 \mathrm{~m} / \mathrm{z}$.
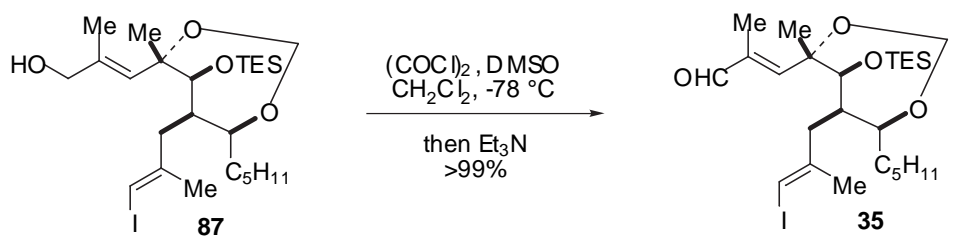

(4S,5S,6R,7S)-2,4-dimethyl-4,7-O-methylidene-6-(E-2' -methyl-3' -iodoprop-2'-enyl)5-[(triethylsilyl)oxy]-dodec-2-en-1-al (35). A solution of $51 \mu \mathrm{L}(0.72 \mathrm{mmol})$ of anhydrous DMSO in $3.0 \mathrm{~mL}$ of $\mathrm{CH}_{2} \mathrm{Cl}_{2}$ was cooled in a dry ice/acetone bath, treated with $47 \mu \mathrm{L}(0.54$ mmol) of oxalyl chloride, and stirred for $15 \mathrm{~min}$ A solution of $205 \mathrm{mg}(0.36 \mathrm{mmol})$ of the allylic alcohol 87 in $300 \mu \mathrm{L}$ of $\mathrm{CH}_{2} \mathrm{Cl}_{2}$ was added dropwise to the reaction mixture, followed by $\mathrm{CH}_{2} \mathrm{Cl}_{2}$ rinse $(0.30 \mathrm{~mL})$. The solution was stirred for $30 \mathrm{~min} \mathrm{Et}_{3} \mathrm{~N}(151 \mu \mathrm{L}, 1.08 \mathrm{mmol})$ was added, and the cloudy reaction mixture was allowed to warm to $0{ }^{\circ} \mathrm{C}$ over $30 \mathrm{~min}$ and stirred at $0{ }^{\circ} \mathrm{C}$ for an additional $10 \mathrm{~min}$ The white suspension was diluted with pentanes $(30 \mathrm{~mL})$, and the reaction was filtered to remove the majority of the $\mathrm{Et}_{3} \mathrm{~N}$ salts. The filtrate was washed with $\mathrm{H}_{2} \mathrm{O}(2 \times 5$ $\mathrm{mL}$ ). The combined organics were washed with saturated aqueous $\mathrm{NaHCO}_{3}$, dried over $\mathrm{MgSO}_{4}$, and concentrated to give $211 \mathrm{mg}(>99 \%)$ of aldehyde 35 as a clear oil: ${ }^{1} \mathrm{H} \mathrm{NMR} \mathrm{(500} \mathrm{MHz,}$ $\left.\mathrm{CDCl}_{3}\right) \delta 9.40(\mathrm{~s}, 1 \mathrm{H}), 6.69(\mathrm{~d}, J=1.4 \mathrm{~Hz}, 1 \mathrm{H}), 6.02(\mathrm{~d}, J=0.8 \mathrm{~Hz}, 1 \mathrm{H}), 4.93\left(\mathrm{~A}\right.$ of $\mathrm{AB}, J_{A B}=$ $6.3 \mathrm{~Hz}, 1 \mathrm{H}), 4.72\left(\mathrm{~B}\right.$ of $\left.\mathrm{AB}, J_{A B}=6.6 \mathrm{~Hz}, 1 \mathrm{H}\right), 4.07(\mathrm{dd}, J=9.3,2.3 \mathrm{~Hz}, 1 \mathrm{H}), 3.86(\mathrm{~d}, J=3.3$ $\mathrm{Hz}, 1 \mathrm{H}), 2.51(\mathrm{~m}, 2 \mathrm{H}), 1.90(\mathrm{~m}, 1 \mathrm{H}), 1.88(\mathrm{~d}, J=1.1 \mathrm{~Hz}, 3 \mathrm{H}), 1.87$ (d, J = 1.4 Hz, $3 \mathrm{H}), 1.67$ $(\mathrm{m}, 1 \mathrm{H}), 1.53(\mathrm{~s}, 3 \mathrm{H}), 1.43(\mathrm{~m}, 1 \mathrm{H}), 1.33-1.25(\mathrm{~m}, 6 \mathrm{H}), 0.95(\mathrm{t}, J=7.8 \mathrm{~Hz}, 9 \mathrm{H}), 0.89(\mathrm{t}, J=$ $6.9 \mathrm{~Hz}, 3 \mathrm{H}), 0.59$ (q, $J=7.8 \mathrm{~Hz}, 6 \mathrm{H}) ;{ }^{13} \mathrm{CNMR}\left(125 \mathrm{MHz}, \mathrm{CDCl}_{3}\right) \delta 195.7,156.8,146.3,138.5$, $90.4,83.7,78.2,76.7,74.4,48.5,37.0,33.0,31.7,26.2,24.1,23.9,22.6,14.0,9.9,7.0$ (3), 5.2 (3); FT-IR (thin film) 3054, 2955, 2932, 2876, 2703, 1693, 1458, 1411, 1376, 1271, 1233, 1199, 
1120, 1062, 1017, 818, $725 \mathrm{~cm}^{-1}$; HRMS (FAB) calcd for $\left[\mathrm{C}_{25} \mathrm{H}_{45} \mathrm{IO}_{4} \mathrm{Si}+\mathrm{Na}\right]^{+} 587.2030$, found $587.2049 \mathrm{~m} / \mathrm{z}$.
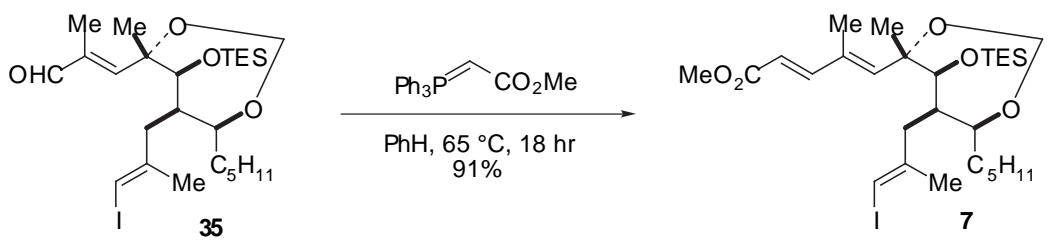

\section{Synthesis of Methyl-(6S,7S,8R,9S)-4,6-dimethyl-6,9-O-methylidene-8-(E-2'-methyl-} 3'-iodoprop-2'-enyl)-7-[(triethylsilyl)oxy]-dodeca-2,4-dienoate (7). A $5 \mathrm{~mL}$ round bottom flask fitted with a cold-finger condensor was charged with $211 \mathrm{mg}(0.36 \mathrm{mmol})$ of aldehyde 35 [pre-dried by coevaporation from $\mathrm{PhH}(2 \times)$ ] and $2 \mathrm{~mL}$ of benzene. Methyl triphenylphosphorylideneacetate $(361 \mathrm{mg}, 1.08 \mathrm{mmol})$ was added in a single portion, and the resulting suspension was heated to $65-70^{\circ} \mathrm{C}$ for $13 \mathrm{~h}$. After being cooled to room temperature, the reaction was diluted with hexanes, filtered and concentrated to remove $\mathrm{Ph}_{3} \mathrm{PO}$ and unreacted methyl triphenylphosphorylideneacetate. The filtrate was concentrated and the preceding process repeated two more times to remove the majority of $\mathrm{Ph}_{3} \mathrm{PO}$ and unreacted methyl triphenylphosphorylideneacetate. The residue was flushed through $5 \mathrm{~g}$ of $\mathrm{SiO}_{2},(15 \%$ EtOAc/hexanes) followed by purification by HPLC to give $189 \mathrm{mg}(85 \%)$ of pure $7:[\alpha]^{24}{ }^{-}$ $9.2^{\circ}\left(c=0.34, \mathrm{CHCl}_{3}\right) ;{ }^{1} \mathrm{H} \mathrm{NMR}\left(500 \mathrm{MHz}, \mathrm{CDCl}_{3}\right) \delta 7.32(\mathrm{~d}, J=15.7 \mathrm{~Hz}, 1 \mathrm{H}), 6.25(\mathrm{~s}, 1 \mathrm{H})$, $6.00(\mathrm{~s}, 1 \mathrm{H}), 5.87(\mathrm{~d}, J=15.7 \mathrm{~Hz}, 1 \mathrm{H}), 4.87\left(\mathrm{~A}\right.$ of $\left.\mathrm{AB}, J_{A B}=6.6 \mathrm{~Hz}, 1 \mathrm{H}\right), 4.72\left(\mathrm{~B}\right.$ of $\mathrm{AB}, J_{A B}=$ $6.6 \mathrm{~Hz}, 1 \mathrm{H}), 3.95(\mathrm{~m}, 1 \mathrm{H}), 3.76(\mathrm{~s}, 3 \mathrm{H}), 3.73(\mathrm{~d}, J=3.6 \mathrm{~Hz}, 1 \mathrm{H}), 2.52\left(\mathrm{~A}\right.$ of $\mathrm{ABX}, J_{A B}=14.6$ $\left.\mathrm{Hz}, J_{A X}=8.6 \mathrm{~Hz}, 1 \mathrm{H}\right), 2.42\left(\mathrm{~B}\right.$ of $\left.\mathrm{ABX}, J_{A B}=14.6 \mathrm{~Hz}, J_{B X}=5.2 \mathrm{~Hz}, 1 \mathrm{H}\right), 1.91(\mathrm{~s}, 3 \mathrm{H}), 1.88(\mathrm{~m}$ H), $1.86(\mathrm{~s}, 3 \mathrm{H}), 1.64(\mathrm{~m} \mathrm{H}), 1.48(\mathrm{~s}, 3 \mathrm{H}), 1.42(\mathrm{~m}, 1 \mathrm{H}), 1.32-1.25(\mathrm{~m}, 6 \mathrm{H}), 0.95(\mathrm{t}, J=8.0 \mathrm{~Hz}$, $9 \mathrm{H}), 0.89(\mathrm{t}, J=6.9 \mathrm{~Hz}, 3 \mathrm{H}), 0.59(\mathrm{q}, J=8.0 \mathrm{~Hz}, 6 \mathrm{H}) ;{ }^{13} \mathrm{CNMR}\left(125 \mathrm{MHz}, \mathrm{CDCl}_{3}\right) \delta 167.8$, $150.5,146.5,142.6,133.9,116.1,90.0,83.2,78.9,76.6,74.9,51.5,49.0,37.9,32.7,31.7,26.2$, 26.1, 24.0, 22.6, 14.0, 13.0, 7.0 (3), 5.2 (3); FT-IR (thin film) 3059, 2954, 2932, 2876, 1722, 
$1623,1458,1433,1377,1298,1270,1170,1121,1074,1019,841,726 \mathrm{~cm}^{-1}$; HRMS (FAB) calcd for $\left[\mathrm{C}_{28} \mathrm{H}_{49} \mathrm{IO}_{5} \mathrm{Si}+\mathrm{Na}\right]^{+}$643.2292, found $643.2295 \mathrm{~m} / \mathrm{z}$.

\section{B. Second Generation Synthesis of Fragment 7.}

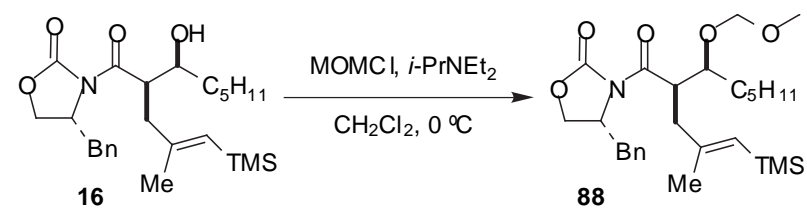

(4R ) 4 - B e n z y l-3-[2-(1'S,2R,4E)-(1'-methoxymethoxy-hexyl)-4-methyl-5(trimethylsilanyl)-pent-4-enoyl]-oxazolidin-2-one (88). To a solution of 16 (15.7 g, 35.3 mmol) and $i$ - $\mathrm{Pr}_{2} \mathrm{NEt}(18.5 \mathrm{~mL}, 105.8 \mathrm{mmol}, 3 \mathrm{eq})$ in $\mathrm{CH}_{2} \mathrm{Cl}_{2}(7.5 \mathrm{~mL})$ at $0{ }^{\circ} \mathrm{C}$ was added $\mathrm{MOMCl}$ (7.7 $\mathrm{mL}, 101.0 \mathrm{mmol}, 2.9 \mathrm{eq})$ dropwise. After $1.5 \mathrm{~h}$ at $0{ }^{\circ} \mathrm{C}$, the reaction mixture was diluted with saturated $\mathrm{NaCl}$ solution and the aqueous layer extracted with $\mathrm{CH}_{2} \mathrm{Cl}_{2}$. The combined organic layers were dried over $\mathrm{MgSO}_{4}$, filtered and concentrated. The crude residue was dissolved in cold hexanes $\left(0^{\circ} \mathrm{C}\right)$, filtered through a pad of Celite ${ }^{\circledR}$ and rinsed thoroughly with hexanes. After concentration, $\mathbf{8 8}$ was obtained as a yellow oil which was used directly in the next step. Purification of an aliquot of $\mathbf{8 8}$ by flash chromatography on silica gel (hexanes / ethyl acetate = $85 / 15$ ) afforded an analytical sample as a colorless oil having the following properties: $[\alpha]_{\mathrm{D}}{ }^{24}=-$ $81.3\left(c \text { 1.55, } \mathrm{CHCl}_{3}\right)^{1} \mathrm{H}$ NMR (500 MHz, $\left.\mathrm{CDCl}_{3}\right) \delta$ 7.35-7.32 (2H), 7.29-7.26 (1H), $7.22(\mathrm{~d}, J=$ $6.8 \mathrm{~Hz}, 2 \mathrm{H}), 5.27(\mathrm{~s}, 1 \mathrm{H}), 4.71(\mathrm{dd}, J=7.1 \mathrm{~Hz}, 1 \mathrm{H}), 4.65(\mathrm{ddd}, J=10.0,6.6$ and $2.9 \mathrm{~Hz}, 1 \mathrm{H})$, $4.54(\mathrm{~d}, J=7.1 \mathrm{~Hz}, 1 \mathrm{H}), 4.50(\mathrm{dt}, J=8.8$ and $4.4 \mathrm{~Hz}, 1 \mathrm{H}), 4.09-4.03(2 \mathrm{H}), 3.76(\mathrm{ddd}, J=8.3$, 4.1 and $4.1 \mathrm{~Hz}, 1 \mathrm{H}), 3.37(\mathrm{~s}, 3 \mathrm{H}), 3.32(\mathrm{dd}, J=13.8$ and $3.0 \mathrm{~Hz}, 1 \mathrm{H}), 2.65(\mathrm{dd}, J=14.3$ and 10.4 $\mathrm{Hz}, 1 \mathrm{H}), 2.57(\mathrm{dd}, J=13.2$ and $10.4 \mathrm{~Hz}, 1 \mathrm{H}), 2.32(\mathrm{dd}, J=13.8$ and $3.8 \mathrm{~Hz}, 1 \mathrm{H}), 1.86(\mathrm{~s}, 3 \mathrm{H})$, 1.64-1.47 (3H), 1.33-1.26 (5H), $0.89(\mathrm{t}, J=6.8 \mathrm{~Hz}, 3 \mathrm{H}), 0.1(\mathrm{~s}, 9 \mathrm{H}) ;{ }^{13} \mathrm{C} \mathrm{NMR}(100 \mathrm{MHz}$, 
$\left.\mathrm{CDCl}_{3}\right) \delta 173.6,153.2,152.1,135.5,129.3,128.9,127.3,125.3,96.1,78.8,65.7,56.0,44.0$, 40.6, 37.9, 32.0, 31.7, 25.6, 22.6, 22.0, 14.0, 0.0; IR (thin film) 2954, 2360, 1783, 1698, 1382, 1247, 1194, 1038, 840, $700 \mathrm{~cm}^{-1}$; HRMS (FAB) for $\mathrm{C}_{27} \mathrm{H}_{43} \mathrm{O}_{5} \mathrm{SiNa}[\mathrm{M}+\mathrm{Na}]^{+}$calcd. 512.2808, found 512.2816 m/z; Anal. cald for $\mathrm{C}_{27} \mathrm{H}_{43} \mathrm{O}_{5} \mathrm{NSi}$ : C, 66.22; H, 8.85; N, 2.86; Found: C, 66.04; $\mathrm{H}$, $9.08 ; \mathrm{N}, 2.49$.
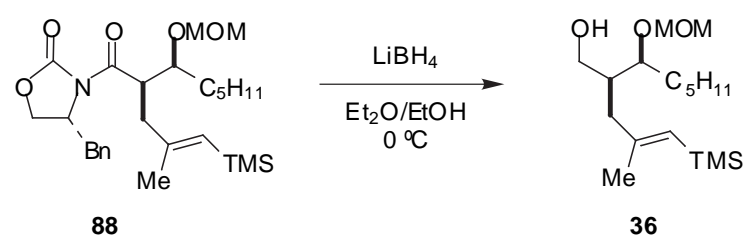

$(1 ' S, 2 S, 4 E)$ 2-(1'-Methoxymethoxy-hexyl)-4-methyl-5-(trimethylsilanyl)-pent-4-en-

1-ol (36). To a solution of $\mathbf{8 8}$ in $\mathrm{Et}_{2} \mathrm{O}(500 \mathrm{~mL})$ and $\mathrm{EtOH}(2.45 \mathrm{~mL}, 42.3 \mathrm{mmol}, 1.2 \mathrm{eq})$ at $0{ }^{\circ} \mathrm{C}$ was added dropwise $\mathrm{LiBH}_{4}(2 \mathrm{M}$ solution in THF, $42.3 \mathrm{mmol}, 21.2 \mathrm{~mL}, 1.2 \mathrm{eq})$. After $4 \mathrm{~h}$ at $0{ }^{\circ} \mathrm{C}$, the reaction mixture was carefully quenched with an aqueous solution of $\mathrm{NaOH}(1 \mathrm{M}, 200 \mathrm{~mL})$ and the solution stirred until clear phases were obtained $(1.5 \mathrm{~h})$. The aqueous layer was extracted with $\mathrm{Et}_{2} \mathrm{O}$, the combined organic layers were washed with saturated $\mathrm{NaCl}$ solution, dried over $\mathrm{MgSO}_{4}$, filtered and concentrated. Purification of the crude material by flash chromatography on silica gel (hexanes / ethyl acetate $=95 / 5$ to $80 / 20$ ) afforded $9.60 \mathrm{~g}$ ( $86 \%$ from 16, two steps) of 36 as a colorless oil: $[\alpha]_{\mathrm{D}}^{24}=+20.1\left(c 1.51, \mathrm{CHCl}_{3}\right) ;{ }^{1} \mathrm{H}$ NMR $\left(400 \mathrm{MHz}, \mathrm{CDCl}_{3}\right) \delta 5.24(\mathrm{~s}, 1 \mathrm{H})$, $4.67(\mathrm{~d}, J=6.8 \mathrm{~Hz}, 1 \mathrm{H}), 4.63(\mathrm{~d}, J=6.8 \mathrm{~Hz}, 1 \mathrm{H}), 3.65(\mathrm{~m}, 1 \mathrm{H}), 3.63(\mathrm{~m}, 1 \mathrm{H}), 3.55(\mathrm{~m}, 1 \mathrm{H})$, $3.40(\mathrm{~s}, 3 \mathrm{H}), 2.81(\mathrm{~m}, 1 \mathrm{H}), 2.11-2.04(2 \mathrm{H}), 1.94(\mathrm{~m}, 1 \mathrm{H}), 1.78(\mathrm{~s}, 3 \mathrm{H}), 1.54(\mathrm{~m}, 1 \mathrm{H}), 1.47-1.42$ $(2 \mathrm{H}), 1.33-1.24(5 \mathrm{H}), 0.88(\mathrm{t}, J=7.0 \mathrm{~Hz}, 3 \mathrm{H}), 0.08(\mathrm{~s}, 9 \mathrm{H}) ;{ }^{13} \mathrm{C} \mathrm{NMR}\left(100 \mathrm{MHz}, \mathrm{CDCl}_{3}\right) \delta$ $152.8,126.0,96.5,79.6,63.5,55.9,40.6$ (2C), 31.8, 30.4, 25.7, 22.6, 21.1, 14.0, -0.1; IR (thin film) $3445,2954,2932,1615,1247,1152,1097,1040,861,837 \mathrm{~cm}^{-1}$; HRMS (CI, $\left.\mathrm{NH}_{3}\right)$ for $\mathrm{C}_{17} \mathrm{H}_{36} \mathrm{O}_{3} \mathrm{Si}[\mathrm{M}+\mathrm{H}]^{+}$calcd. 317.2512, found $317.2500 \mathrm{~m} / z$; Anal. cald for $\mathrm{C}_{17} \mathrm{H}_{36} \mathrm{O}_{3} \mathrm{Si}$ : C, 64.50; H, 11.46; Found: C, 64.81; H, 11.08. 

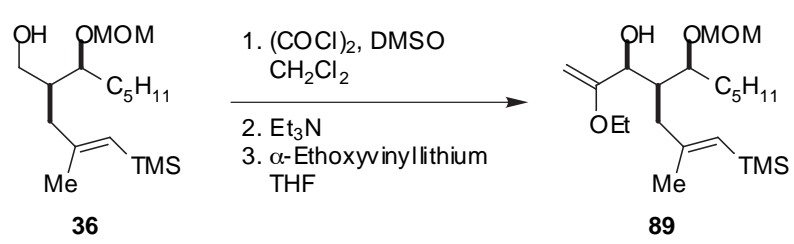

$(1 ' S, 3 S, 4 R, 6 E) \quad 2$ - Eth oxy - 4 - (1'- methoxy meth oxy - hexyl) - 6 - met hy l-7 (trimethylsilanyl)-hepta-1,6-dien-3-ol (89): To a solution of oxalyl chloride (2.2 mL, 25.2 mmol, 2 eq) in $\mathrm{CH}_{2} \mathrm{Cl}_{2}(100 \mathrm{~mL})$ at $-70{ }^{\circ} \mathrm{C}$ was added dropwise dry DMSO (2.6 mL, $36.6 \mathrm{mmol}$, 3 eq). After $15 \mathrm{~min}$ at $-70{ }^{\circ} \mathrm{C}$, a solution of $36(3.90 \mathrm{~g}, 12.3 \mathrm{mmol})$ in $\mathrm{CH}_{2} \mathrm{Cl}_{2}(20 \mathrm{~mL})$ was added slowly via canula. The reaction mixture was stirred for another $15 \mathrm{~min}$ at $-70{ }^{\circ} \mathrm{C}$ before addition of $\mathrm{Et}_{3} \mathrm{~N}(7.0 \mathrm{~mL}, 50.2 \mathrm{mmol}, 4 \mathrm{eq})$. The reaction mixture was allowed to warm to $0{ }^{\circ} \mathrm{C}$ over a 35 min period and then stirred at $0{ }^{\circ} \mathrm{C}$ for $15 \mathrm{~min}$. Cold hexanes $(150 \mathrm{~mL})$ were then added and the resulting suspension was filtered through Celite ${ }^{\circledR}$, the filter cake was rinsed thoroughly with cold hexanes, and the filtrate was concentrated. The residue was dissolved in hexanes and washed with water (x3). The the aqueous washes were combined and extracted with ether (x3). The organic layers were combined, washed with saturated $\mathrm{NaCl}$ solution, dried over $\mathrm{MgSO}_{4}$, filtered and concentrated to give a slightly yellow oil which was used directly in the next step without any purification.

To a solution of ethylvinyl ether $(10.6 \mathrm{~mL}, 111 \mathrm{mmol})$ in $\mathrm{THF}(15 \mathrm{~mL})$ at $-78{ }^{\circ} \mathrm{C}$ was added $t$-BuLi $(1.7 \mathrm{M}$ in pentane, $85.0 \mathrm{mmol}, 50 \mathrm{~mL})$ dropwise such that $\mathrm{T}<-60{ }^{\circ} \mathrm{C}$. The reaction mixture was then warmed to $0{ }^{\circ} \mathrm{C}$, stirred at that temperature for $30 \mathrm{~min}$, cooled to $-78{ }^{\circ} \mathrm{C}$ and diluted with THF (30 mL). The solution of $\alpha$-ethoxyvinyllithium was then further cooled to -118 ${ }^{\circ} \mathrm{C}$ (internal temperature, pentane $/ \mathrm{N}_{2(l)}$ bath) and a solution of the crude aldehyde in $\mathrm{THF}(20 \mathrm{~mL})$ was then slowly added such that the internal reaction temperature was $<-115^{\circ} \mathrm{C}$. After $20 \mathrm{~min}$ at $-118^{\circ} \mathrm{C}$, the reaction mixture was quenched by slow addition of $\mathrm{MeOH}(5 \mathrm{~mL})$ followed by an aqueous saturated solution of $\mathrm{NaHCO}_{3}(5 \mathrm{~mL})$ and the resulting mixture was allowed to warm to $0{ }^{\circ} \mathrm{C}$. The reaction mixture was diluted with water. The aqueous layer was separated and extracted with $\mathrm{CH}_{2} \mathrm{Cl}_{2}$ (x4). The organic layers were combined, washed with saturated $\mathrm{NaCl}$ 
solution, dried over $\mathrm{K}_{2} \mathrm{CO}_{3}$, filtered, and concentrated to give a slightly yellow oil (4.9 $\left.\mathrm{g}\right)$. This material was used directly in the next reaction. Purification of a small aliquot by flash chromatography on silica gel (hexanes / ethyl acetate $=95 / 5$ ) gave an analytical sample of $\mathbf{8 9}$ as a colorless oil. $[\alpha]_{\mathrm{D}}{ }^{25}=-3.3\left(c 1.04, \mathrm{CHCl}_{3}\right) ;{ }^{1} \mathrm{H} \mathrm{NMR}\left(500 \mathrm{MHz}, \mathrm{CDCl}_{3}\right) \delta 5.28(\mathrm{~s}, 1 \mathrm{H}), 4.65(\mathrm{~s}$, $2 \mathrm{H}), 4.27(\mathrm{t}, J=3.7 \mathrm{~Hz}, 1 \mathrm{H}), 4.22(\mathrm{~d}, J=1.7 \mathrm{~Hz}, 1 \mathrm{H}), 4.01(\mathrm{~d}, J=1.7 \mathrm{~Hz}, 1 \mathrm{H}), 3.78-3.68(2 \mathrm{H})$, $3.63(\mathrm{dt}, J=6.7$ and $2.7 \mathrm{~Hz}, 1 \mathrm{H}), 3.38(\mathrm{~s}, 3 \mathrm{H}), 2.70(\mathrm{~d}, J=4.2 \mathrm{~Hz}, 1 \mathrm{H}), 2.31(\mathrm{dd}, J=13.9$ and $7.6 \mathrm{~Hz}, 1 \mathrm{H}), 2.25(\mathrm{~m}, 1 \mathrm{H}), 2.18(\mathrm{dd}, J=13.9$ and $7.6 \mathrm{~Hz}, 1 \mathrm{H}), 1.75(\mathrm{~s}, 3 \mathrm{H}), 1.62-1.53(2 \mathrm{H})$, 1.35-1.17 (9H including $1.27(\mathrm{t}, J=7.1 \mathrm{~Hz}, 3 \mathrm{H})), 0.87(\mathrm{t}, J=7.1 \mathrm{~Hz}, 3 \mathrm{H}), 0.07(\mathrm{~s}, 9 \mathrm{H}) ;{ }^{13} \mathrm{C}$ NMR $\left(125 \mathrm{MHz}, \mathrm{CDCl}_{3}\right) \delta 162.7,154.9,124.7,95.8,81.7,81.0,74.3,62.7,55.7,40.9,37.0$, 31.8, 31.3, 26.0, 22.7, 21.2, 14.4, 14.0, -0.1; IR (thin film) 3468 (br), 2955, 2361, 1662, 1616, 1247, 1100, 1040, 870, $840 \mathrm{~cm}^{-1}$; HRMS (CI, $\mathrm{NH}_{3}$ ) for $\mathrm{C}_{21} \mathrm{H}_{42} \mathrm{O}_{4} \mathrm{Si}[\mathrm{M}+\mathrm{H}]^{+}$calcd. 387.2931, found $387,2985 \mathrm{~m} / \mathrm{z}$.

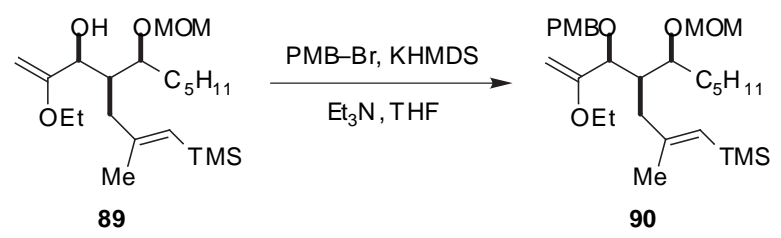

\section{$(1 ' S, 3 S, 4 R, 6 E)$ 2-Ethoxy-3-p-methoxybenzyloxy-4-(1'-methoxymethoxy-hexyl)-6-} methyl-7-(trimethylsilanyl)-hepta-1,6-diene (90). To a $0{ }^{\circ} \mathrm{C}$ solution of 89 (4.9 g, used crude from the previous reaction) in THF $(120 \mathrm{~mL})$ was added $\mathrm{Et}_{3} \mathrm{~N}(5.2 \mathrm{~mL}, 75.0 \mathrm{mmol}, 3 \mathrm{eq})$, PMB-Br (3.5 mL, $24.3 \mathrm{mmol}, 2$ eq) followed by KHMDS (0.5 M in toluene, $30 \mathrm{~mL}, 15 \mathrm{mmol}, 1$ eq). After $1.5 \mathrm{~h}$ at $0{ }^{\circ} \mathrm{C}$, the reaction was complete by TLC analysis. The crude reaction mixture was used directly in the next reaction. An analytical sample of $\mathbf{9 0}$ was obtained by removal of a small aliquot of the crude reaction mixture and quenching with an aqueous saturated solution of $\mathrm{NaHCO}_{3}$. The aqueous layer was extracted with ethyl acetate and the combined organic layers washed with saturated $\mathrm{NaCl}$ solution, dried over $\mathrm{MgSO}_{4}$, filtered and concentrated. Purification of the crude material by flash chromatography on silica gel (hexanes / ethyl acetate $=100 / 3+$ 
$\left.1 \% \mathrm{NEt}_{3}\right)$ afforded 90 as a colorless oil. $[\alpha]_{\mathrm{D}}{ }^{25}=-73.7\left(c 1.38, \mathrm{CHCl}_{3}\right) ;{ }^{1} \mathrm{H} \mathrm{NMR}(500 \mathrm{MHz}$, $\left.\mathrm{CDCl}_{3}\right) \delta 7.27(\mathrm{~d}, J=8.7 \mathrm{~Hz}, 2 \mathrm{H}), 6.88(\mathrm{~d}, J=8.7 \mathrm{~Hz}, 2 \mathrm{H}), 5.25(\mathrm{~s}, 1 \mathrm{H}), 4.70(\mathrm{~d}, J=6.8 \mathrm{~Hz}$, $1 \mathrm{H}), 4.59(\mathrm{~d}, J=6.8 \mathrm{~Hz}, 1 \mathrm{H}), 4.55(\mathrm{~d}, J=11.0 \mathrm{~Hz}, 1 \mathrm{H}), 4.30(\mathrm{~d}, J=11.0 \mathrm{~Hz}, 1 \mathrm{H}), 4.20(\mathrm{~d}, J=$ $1.8 \mathrm{~Hz}, 1 \mathrm{H}), 4.13(\mathrm{~d}, J=1.8 \mathrm{~Hz}, 1 \mathrm{H}), 3.95(\mathrm{~d}, J=3.9 \mathrm{~Hz}, 1 \mathrm{H}), 3.82(\mathrm{~s}, 3 \mathrm{H}), 3.81-3.76(2 \mathrm{H})$, $3.52(\mathrm{dt}, J=8.8$ and $3.4 \mathrm{~Hz}, 1 \mathrm{H}), 3.39(\mathrm{~s}, 3 \mathrm{H}), 2.45(\mathrm{dd}, J=13.9$ and $3.4 \mathrm{~Hz}, 1 \mathrm{H}), 2.29(\mathrm{~m}, 1 \mathrm{H})$, $2.14(\mathrm{dd}, J=13.9$ and $10.6 \mathrm{~Hz}, 1 \mathrm{H}), 1.77(\mathrm{~s}, 3 \mathrm{H}), 1.66(\mathrm{~m}, 1 \mathrm{H}), 1.50-1.41(2 \mathrm{H}), 1.35-1.20(8 \mathrm{H}$ including $1.32(\mathrm{t}, J=7.0 \mathrm{~Hz}, 3 \mathrm{H})), 0.91(\mathrm{t}, J=7.1 \mathrm{~Hz}, 3 \mathrm{H}), 0.10(\mathrm{~s}, 9 \mathrm{H}) ;{ }^{13} \mathrm{C} \mathrm{NMR}(125 \mathrm{MHz}$, $\left.\mathrm{CDCl}_{3}\right) \delta 160.5,158.9,154.3,130.9,129.2,125.1,113.5,96.1,82.7,78.7,78.5,70.3,62.7,55.5$, $55.2,41.1,38.9,31.7,30.8,26.3,22.7,21.0,14.4,14.1,0.0$; IR (thin film) $2954,1615,1515$, 1248, 1098, 1038, 869, $837 \mathrm{~cm}^{-1}$; HRMS (FAB) for $\mathrm{C}_{29} \mathrm{H}_{50} \mathrm{O}_{5} \mathrm{SiNa}[\mathrm{M}+\mathrm{Na}]^{+}$calcd. 529.3325, found $529.3322 \mathrm{~m} / \mathrm{z}$.
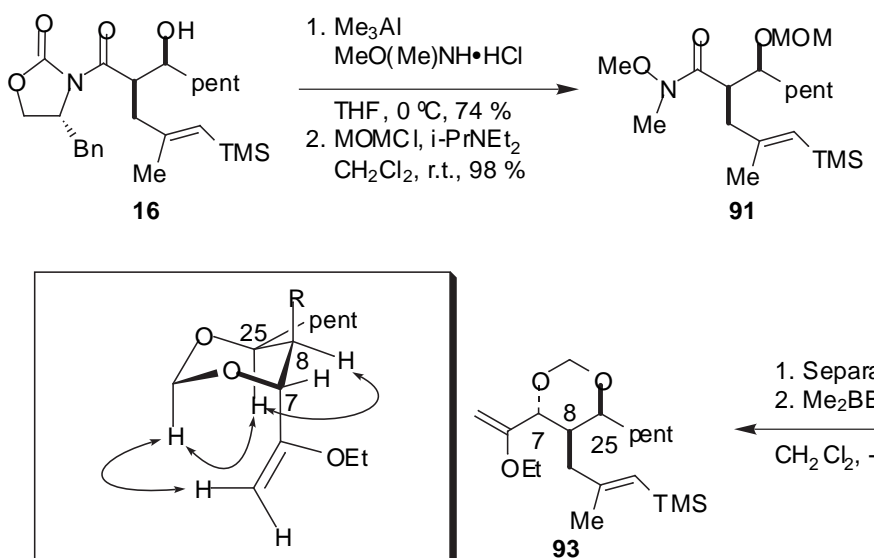

Observed NOE enhancements
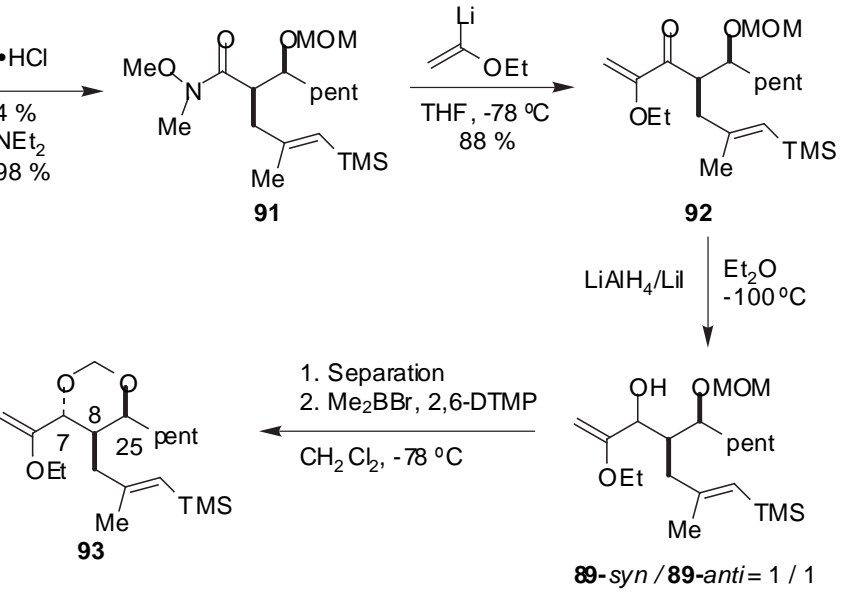

Stereochemical assignment of $\mathbf{8 9}$ was made as follows: Aldol $\mathbf{1 6}$ was converted to the $\beta$ methoxymethoxy Weinreb amide 91 in 2 steps (73\%). Displacement of the amide moiety by $\alpha$ ethoxyvinyllithium in THF to give $\mathbf{9 2}$, followed by non-selective reduction of the ketone function afforded a 1/1 mixture of 89-syn and 89-anti. Formation of the cyclic acetal 93 was effected by treatment with $\mathrm{Me}_{2} \mathrm{BBr}$ and 2,6-DTMP. NOE experiments on the acetal derived from 89-syn were not conclusive. However, NOE enhancements were observed for $\mathbf{9 3}$ (derived from 
89-anti) between the vinylic and acetal protons, $\mathrm{C}(8)-\mathrm{H}$ and $\mathrm{C}(25)-\mathrm{H}$, and $\mathrm{C}(25)-\mathrm{H}$ and the acetal proton. This indicates an anti relationship between $\mathrm{C}(7)-\mathrm{H}$ and (C8)-H and a syn relationship between $\mathrm{C}(8)-\mathrm{H}$ and $\mathrm{C}(25)-\mathrm{H}$. Therefore, by deduction, compound 89-syn must possess a syn,syn relationship between the $\mathrm{C}(7)-\mathrm{C}(8)$ and $\mathrm{C}(8)-\mathrm{C}(25)$ stereocenters.

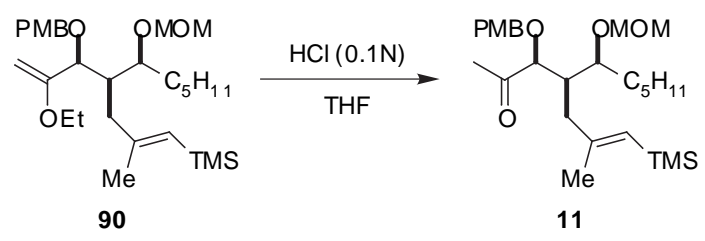

$(1 ' S, 3 S, 4 R, 6 E)$ 3-p-Methoxybenzyloxy-4-(1'-methoxymethoxy-hexyl)-6-methyl-7(trimethylsilanyl)-hept-6-en-2-one (11). To the crude reaction mixture containing PMB ether 90 (from the previous experiment) at $0^{\circ} \mathrm{C}$ was slowly added dropwise $\mathrm{HCl}(1 \mathrm{~N}, 10 \mathrm{~mL})$. After 10 min, additional $\mathrm{HCl}$ solution $(90 \mathrm{~mL})$ was added. The reaction was slowly warmed to $23{ }^{\circ} \mathrm{C}$ and stirred for $30 \mathrm{~min}$. The crude reaction was then poured into a separatory funnel and the aqueous layer was separated. The aqueous layer was extracted with $\mathrm{CH}_{2} \mathrm{Cl}_{2}(\mathrm{x} 4)$. The organic layers were then combined and washed successively with an aqueous saturated solution of $\mathrm{NaHCO}_{3}(\mathrm{x} 2)$ and saturated $\mathrm{NaCl}$ solution, dried over $\mathrm{Na}_{2} \mathrm{SO}_{4}$, filtered and concentrated. Purification of the crude mixture by flash chromatography (95:5 $\rightarrow 90: 10$ hexanes/EtOAc) provided 11 as a yellow oil (4.66 g, 79\% from 36): $[\alpha]_{\mathrm{D}}{ }^{25}=-83.0\left(c 0.43, \mathrm{CHCl}_{3}\right) ;{ }^{1} \mathrm{H}$ NMR $\left(400 \mathrm{MHz}, \mathrm{CDCl}_{3}\right) \delta 7.21(\mathrm{~d}, J$ $=8.8 \mathrm{~Hz}, 2 \mathrm{H}), 6.84(\mathrm{~d}, J=8.8 \mathrm{~Hz}, 2 \mathrm{H}), 5.20(\mathrm{~s}, 1 \mathrm{H}), 4.62(\mathrm{~d}, J=6.6 \mathrm{~Hz}, 1 \mathrm{H}), 4.50(\mathrm{~d}, J=6.6$ $\mathrm{Hz}, 1 \mathrm{H}), 4.42(\mathrm{~d}, J=11.0 \mathrm{~Hz}, 1 \mathrm{H}), 4.27(\mathrm{~d}, J=11.0 \mathrm{~Hz}, 1 \mathrm{H}), 3.86(\mathrm{~d}, J=4.4 \mathrm{~Hz}, 1 \mathrm{H}), 3.76(\mathrm{~s}$, $3 \mathrm{H}), 3.46(\mathrm{dt}, J=9.2$ and $2.9 \mathrm{~Hz}, 1 \mathrm{H}), 3.33(\mathrm{~s}, 3 \mathrm{H}), 2.38-2.28(2 \mathrm{H}), 2.12(\mathrm{~s}, 3 \mathrm{H}), 2.03(\mathrm{dd}, J=$ 13.4 and $9.0 \mathrm{~Hz}, 1 \mathrm{H}), 1.69(\mathrm{~s}, 3 \mathrm{H}), 1.54-1.36(3 \mathrm{H}), 1.27-1.14(5 \mathrm{H}), 0.84(\mathrm{t}, J=7.0 \mathrm{~Hz}, 3 \mathrm{H}), 0.03$ $(\mathrm{s}, 9 \mathrm{H}) ;{ }^{13} \mathrm{C}$ NMR $\left(100 \mathrm{MHz}, \mathrm{CDCl}_{3}\right) \delta 211.3,159.3,152.3,129.7,129.4,129.6,113.7,96.2$, $84.3,78.0,72.1,55.8,42.4,39.8,31.6,30.0,26.5,26.2,22.6,21.0,14.0,-0.1$; IR (thin film) 2954, 1715, 1614, 1515, 1249, 1035, $838 \mathrm{~cm}^{-1}$; HRMS (ES) for $\mathrm{C}_{27} \mathrm{H}_{46} \mathrm{O}_{5} \mathrm{SiNa}[\mathrm{M}+\mathrm{Na}]^{+}$calcd. 501.3012 , found $501.3020 \mathrm{~m} / \mathrm{z}$. 


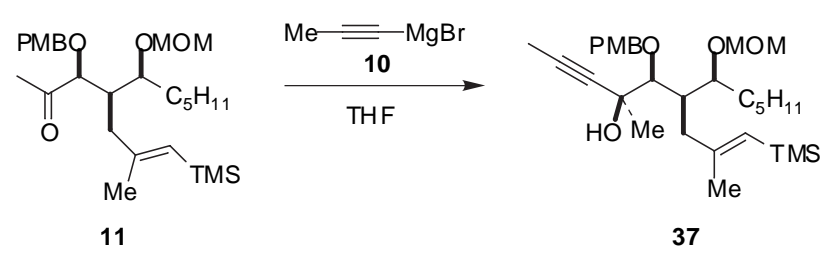

(1'S,4S,5S,6R,8E) 5- $p$-Methoxybenzyloxy-6-(1'-methoxymethoxy-hexyl)-4,8-dimethyl9-(trimethylsilanyl)-non-8-en-2-yn-4-ol (37): To a solution of 11 (4.3 g, $9.0 \mathrm{mmol})$ in THF (80 $\mathrm{mL}$ ) at $-45^{\circ} \mathrm{C}$ was added 1-propynylmagnesium bromide (0.5 M in THF, $25 \mathrm{mmol}, 50 \mathrm{~mL}, 2.8$ eq). After $12 \mathrm{~h}$ at $-45^{\circ} \mathrm{C}$, the reaction mixture was allowed to warm to $-30{ }^{\circ} \mathrm{C}$ and stirred $3 \mathrm{~h}$ at that temperature. The reaction was then poured into an aqueous saturated solution of $\mathrm{NH}_{4} \mathrm{Cl}$ and the aqueous layer extracted with $\mathrm{CH}_{2} \mathrm{Cl}_{2}$. The combined organic layers were dried over $\mathrm{MgSO}_{4}$, filtered and concentrated. Purification of the crude material by flash chromatography on silica gel (hexanes / ethyl acetate $=85 / 15$ to 70/30) afforded $4.36 \mathrm{~g}(94 \%)$ of 37 as a colorless oil: $[\alpha]_{\mathrm{D}}^{25}=-87.9\left(c 0.33, \mathrm{CHCl}_{3}\right) ;{ }^{1} \mathrm{H} \mathrm{NMR}\left(500 \mathrm{MHz}, \mathrm{CDCl}_{3}\right) \delta 7.27(\mathrm{~d}, J=8.8 \mathrm{~Hz}, 2 \mathrm{H}), 6.87(\mathrm{~d}, J$ $=8.8 \mathrm{~Hz}, 2 \mathrm{H}), 5.24(\mathrm{~s}, 1 \mathrm{H}), 4.73(\mathrm{~d}, J=6.8 \mathrm{~Hz}, 1 \mathrm{H}), 4.70(\mathrm{~d}, J=10.7 \mathrm{~Hz}, 1 \mathrm{H}), 4.57(\mathrm{~d}, J=6.8$ $\mathrm{Hz}, 1 \mathrm{H}), 4.54(\mathrm{~d}, J=10.7 \mathrm{~Hz}, 1 \mathrm{H}), 4.30(\mathrm{~s}, 1 \mathrm{H}), 3.80(\mathrm{~s}, 3 \mathrm{H}), 3.66(\mathrm{~m}, 1 \mathrm{H}), 3.45(\mathrm{~d}, J=5.1 \mathrm{~Hz}$, 1H), $3.39(\mathrm{~s}, 3 \mathrm{H}), 2.68(\mathrm{dd}, J=13.7$ and $3.8 \mathrm{~Hz}, 1 \mathrm{H}), 2.56(\mathrm{~m}, 1 \mathrm{H}), 2.00(\mathrm{dd}, J=13.7$ and 11.8 $\mathrm{Hz}, 1 \mathrm{H}), 1.83$ (s, 3H), 1.79 (s, 3H), 1.62-1.47 (5H including 1.52 (s, 3H)), 1.32-1.23 (6H), 0.90 $(\mathrm{t}, J=7.1 \mathrm{~Hz}, 3 \mathrm{H}), 0.10(\mathrm{~s}, 9 \mathrm{H}) ;{ }^{13} \mathrm{C}$ NMR $\left(125 \mathrm{MHz}, \mathrm{CDCl}_{3}\right) \delta$ 159.1, 153.5, 130.6, 129.3, 129.5, 113.7, 95.2, 83.6, 82.5, 80.2, 77.6, 74.4, 71.6, 55.9, 55.2, 41.1, 40.4, 31.6, 29.6, 27.3, 26.4, 22.7, 20.8, 14.1, 3.8, -0.1; IR (thin film) 3409 (br), 2954, 2252, 1614, 1515, 1456, 1249, 1095, 1036, 869, $840 \mathrm{~cm}^{-1}$; HRMS (ES) for $\mathrm{C}_{30} \mathrm{H}_{50} \mathrm{O}_{5} \mathrm{SiNa}[\mathrm{M}+\mathrm{Na}]^{+}$calcd. 541.3325, found 541.3315 $\mathrm{m} / \mathrm{z}$. 


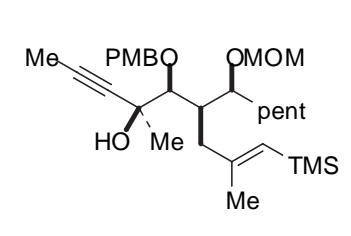

37

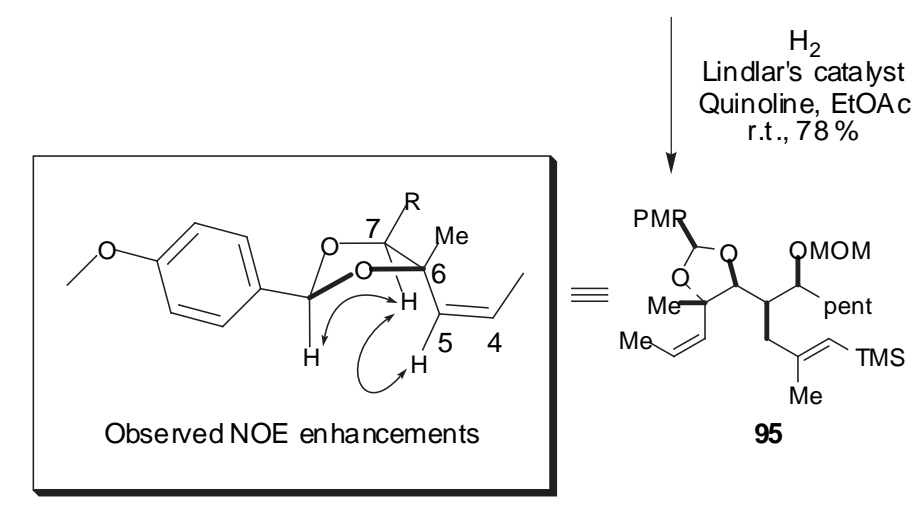

The stereochemistry of $\mathbf{3 7}$ was assigned as follows: DDQ oxidation of PMB ether $\mathbf{3 7}$ gave the $p$-methoxylidene (PMP) acetal 94. Semi-hydrogenation of the triple bond with $\mathrm{H}_{2}$ and Lindlar's catalyst afforded 95. Key ${ }^{1} \mathrm{H}$ NOE enhancements were observed between C(5)-H, C(7)$\mathrm{H}$, and the acetal methine proton, indicating a syn relationship for the $\mathrm{C}(6)-\mathrm{C}(7)$ hydroxyl functions in 37 .

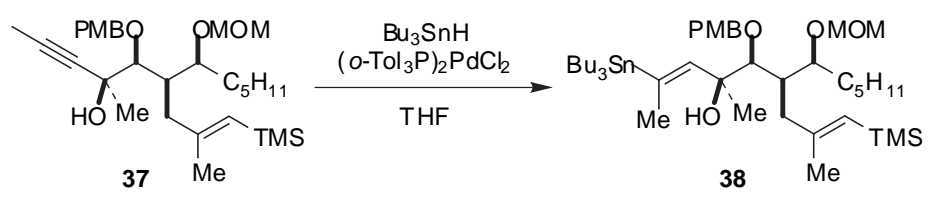

$(1 ' S, 2 E, 4 S, 5 S, 6 R, 8 E)$ 2-[(Tributyl)stannyl]-4,8-dimethyl-5-p-methoxybenzyloxy-6(1'-methoxymethoxy-hexyl)-9-(trimethylsilanyl)-nona-2,8-dien-4-ol (38): A round-bottom flask equipped with an argon balloon was charged with 37 (3.47 g, $6.69 \mathrm{mmol}),\left(o-\mathrm{Tol}_{3} \mathrm{P}\right)_{2} \mathrm{PdCl}_{2}$ (530 mg, $0.67 \mathrm{mmol}, 0.1$ equiv), and THF (12 mL). The resulting heterogeneous mixture was stirred for $20 \mathrm{~min}$ at $23{ }^{\circ} \mathrm{C} . \mathrm{Bu}_{3} \mathrm{SnH}(17 \mathrm{~mL}, 63.2 \mathrm{mmol}, 10 \mathrm{eq})$ was then added via a syringe pump over $2 \mathrm{~h}$. The resulting mixture was then stirred for an additional $10 \mathrm{~min}$ and then diluted with hexanes and filtered through Celite ${ }^{\circledR}$. The filtrate was concentrated and the residue purified 
by flash chromatography on silica gel (hexanes / ethyl acetate $=95 / 5$ to $90 / 10$ ) to provide $4.83 \mathrm{~g}$ of $38(89 \%)$ as a light yellow oil: $[\alpha]_{\mathrm{D}}{ }^{25}=-27.6\left(c 0.54, \mathrm{CHCl}_{3}\right) ;{ }^{1} \mathrm{H} \mathrm{NMR}\left(400 \mathrm{MHz}, \mathrm{CDCl}_{3}\right) \delta$ $7.25(\mathrm{~d}, J=8.6 \mathrm{~Hz}, 2 \mathrm{H}), 6.87(\mathrm{~d}, J=8.6 \mathrm{~Hz}, 2 \mathrm{H}), 5.73\left(\mathrm{~d}, J=1.8 \mathrm{~Hz}, J_{S n-H}=79.7 \mathrm{~Hz}, 1 \mathrm{H}\right), 5.22$ $(\mathrm{s}, 1 \mathrm{H}), 4.65(\mathrm{~d}, J=11.0 \mathrm{~Hz}, 1 \mathrm{H}), 4.64(\mathrm{~d}, J=6.6 \mathrm{~Hz}, 1 \mathrm{H}), 4.51(2 \mathrm{H}), 3.81(\mathrm{~s}, 1 \mathrm{H}), 3.80(\mathrm{~s}, 3 \mathrm{H})$, $3.59(\mathrm{~m}, 1 \mathrm{H}), 3.50(\mathrm{~d}, J=4.8 \mathrm{~Hz}, 1 \mathrm{H}), 3.37(\mathrm{~s}, 3 \mathrm{H}), 2.65(\mathrm{dd}, J=13.8$ and $3.7 \mathrm{~Hz}, 1 \mathrm{H}), 2.35(\mathrm{~m}$, $1 \mathrm{H}), 2.16\left(\mathrm{~s}, J_{S n-H}=24.5 \mathrm{~Hz}, 3 \mathrm{H}\right), 2.02(\mathrm{dd}, J=13.8$ and $11.7 \mathrm{~Hz}, 1 \mathrm{H}), 1.77(\mathrm{~s}, 3 \mathrm{H}), 1.59-1.39$ $(11 \mathrm{H}), 1.34-1.23(12 \mathrm{H}), 0.93-0.80(18 \mathrm{H}), 0.09(\mathrm{~s}, 9 \mathrm{H}) ;{ }^{13} \mathrm{C} \mathrm{NMR}\left(100 \mathrm{MHz}, \mathrm{CDCl}_{3}\right) \delta 158.9$, $153.7,144.5,140.7,131.0,128.5,126.2,113.6,95.3,84.1,78.7,78.0,74.0,55.8,55.2,41.0$, 40.2, 31.7, 29.8, $29.2\left(J_{S n-C}=19.1 \mathrm{~Hz}\right), 27.4\left(J_{S n-C}=54.2 \mathrm{~Hz}\right), 26.5,22.7,20.9,20.7,14.1,13.7$, $9.2\left(J_{S n-C}=309.8 \mathrm{~Hz}\right),-0.1$; IR (thin film) 3414, 2955, 1614, 1514, 1250, 1090, 1040, 868, 840 $\mathrm{cm}^{-1}$; HRMS (ES) for $\mathrm{C}_{42} \mathrm{H}_{78} \mathrm{O}_{5} \mathrm{SiSnNa}[\mathrm{M}+\mathrm{Na}]^{+}$calcd. 833.4538 , found $833.4570 \mathrm{~m} / z$.
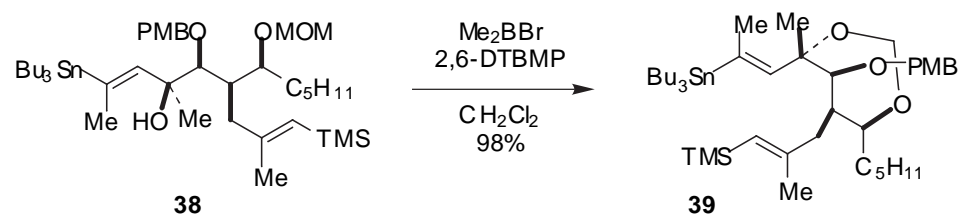

\section{$(1 ’ S, 2 E, 4 S, 5 S, 6 R)-2-[($ Tributyl)stannyl]-4-methyl-4,7-O-methylidene-5-p-}

methoxybenzyloxy-6-(E-2'-methyl-3'-trimethylsilanyl-2'-enyl) dodec-2-ene (39): To a solution of 38 (4.83 g, $5.96 \mathrm{mmol}$ ) and 2,6-di-t-butyl-4-methylpyridine (2,6-DTBMP) (4.82 g, $23.5 \mathrm{mmol}, 4$ equiv) in $\mathrm{CH}_{2} \mathrm{Cl}_{2}(120 \mathrm{~mL})$ at $-78^{\circ} \mathrm{C}$ was added $\mathrm{Me}_{2} \mathrm{BBr}(1.7 \mathrm{~mL}, 17.4 \mathrm{mmol}, 3$ equiv) dropwise. After $30 \mathrm{~min}$, the reaction mixture was slowly warmed to $-50{ }^{\circ} \mathrm{C}$ over a period of $15 \mathrm{~min}$ The reaction was stirred at $-50^{\circ} \mathrm{C}$ for $15 \mathrm{~min}$, at which point TLC analysis indicated complete consumption of $\mathbf{3 8}$. The reaction mixture was then poured into an aqueous saturated solution of $\mathrm{NaHCO}_{3}$, and the aqueous layer was extracted with $\mathrm{CH}_{2} \mathrm{Cl}_{2}$ (x4). The organic layers were then combined, washed with saturated $\mathrm{NaCl}$ solution, dried over $\mathrm{Na}_{2} \mathrm{SO}_{4}$, filtered, and concentrated. Purification of the crude material by flash chromatography on silica gel (hexanes / ethyl acetate $=97 / 3$ to $95 / 5)$ afforded $4.53 \mathrm{~g}(98 \%)$ of 39 as a light yellow oil: $[\alpha]_{\mathrm{D}}{ }^{25}=-39.5^{\circ}(c$ 
0.20, $\left.\mathrm{CHCl}_{3}\right) ;{ }^{1} \mathrm{H} \mathrm{NMR}\left(500 \mathrm{MHz}, \mathrm{CDCl}_{3}\right) \delta 7.24(\mathrm{~d}, J=8.7 \mathrm{~Hz}, 2 \mathrm{H}), 6.86(\mathrm{~d}, J=8.7 \mathrm{~Hz}, 2 \mathrm{H})$, $5.81\left(\mathrm{~d}, J=1.7 \mathrm{~Hz}, J_{S n-H}=77.4 \mathrm{~Hz}, 1 \mathrm{H}\right), 5.33(\mathrm{~s}, 1 \mathrm{H}), 4.92(\mathrm{~d}, J=6.5 \mathrm{~Hz}, 1 \mathrm{H}), 4.87(\mathrm{~d}, J=6.5$ $\mathrm{Hz}, 1 \mathrm{H}), 4.46(\mathrm{~d}, J=11.3 \mathrm{~Hz}, 1 \mathrm{H}), 4.43(\mathrm{~d}, J=11.3 \mathrm{~Hz}, 1 \mathrm{H}), 4.06(\mathrm{~m}, 1 \mathrm{H}), 3.81(\mathrm{~s}, 3 \mathrm{H}), 3.41$ $(\mathrm{d}, J=3.9 \mathrm{~Hz}, 1 \mathrm{H}), 2.39(\mathrm{dd}, J=13.9$ and $9.0 \mathrm{~Hz}, 1 \mathrm{H}), 2.32(\mathrm{dd}, J=13.9$ and $5.9 \mathrm{~Hz}, 1 \mathrm{H}), 2.17$ $(\mathrm{m}, 1 \mathrm{H}), 2.00\left(\mathrm{~d}, J=2.0 \mathrm{~Hz}, J_{S n-H}=49 \mathrm{~Hz}, 3 \mathrm{H}\right), 1.75(\mathrm{~s}, 3 \mathrm{H}), 1.65-1.24(23 \mathrm{H}), 0.96-0.79(18 \mathrm{H})$, $0.12(\mathrm{~s}, 9 \mathrm{H}) ;{ }^{13} \mathrm{C}$ NMR $\left(125 \mathrm{MHz}, \mathrm{CDCl}_{3}\right) \delta$ 159.0, 153.5, 141.8, 140.8, 1309.9, 128.9, 126.4, 113.6, 89.3, 85.5, 83.7, 75.0, 72.9, 55.2, 45.0, 41.1, 32.4, 31.8, $29.2\left(J_{S n-C}=19.7 \mathrm{~Hz}\right), 27.4\left(J_{S n-C}\right.$ $=54.0 \mathrm{~Hz}), 26.3,25.0,22.6,21.2,20.8,14.1,13.7,9.3\left(J_{S n-C}=318.6 \mathrm{~Hz}\right), 0.0$; IR (thin film) 2926, 1614, 1514, 1464, 1248, 1040, 865, $840 \mathrm{~cm}^{-1}$; HRMS (ES) for $\mathrm{C}_{41} \mathrm{H}_{74} \mathrm{O}_{5} \mathrm{SiSnNa}[\mathrm{M}+\mathrm{Na}]^{+}$ calcd. 801.4276 , found $801.4299 \mathrm{~m} / \mathrm{z}$.
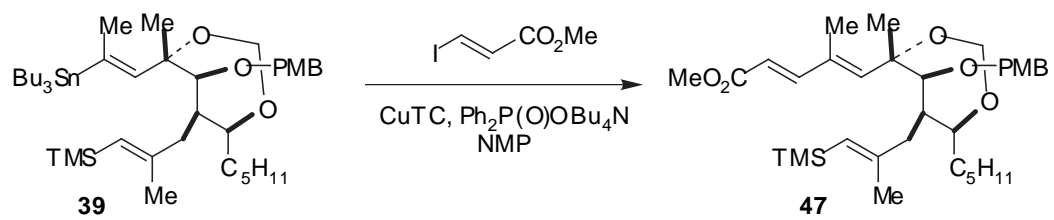

\section{Methyl-(2E,4E,6S,7S,8R,9S)-4,6-dimethyl-6,9-O-methylidene-8-(E-2'-methyl-3'-}

trimethylsilanyl-2'-enyl)-7-p-methoxybenzyloxy-tetradeca-2,4-dienoate (47). A three-neck round-bottom flask fitted with three rubber septa was charged with 12 (2.26 g, 2.91 mmol), tetrabutylammonium diphenylphosphinate ${ }^{5}$ (1.52 g, $\left.3.31 \mathrm{mmol}, 1.1 \mathrm{eq}\right)$, and dry NMP $(16 \mathrm{~mL})$ under a nitrogen atmosphere. In a separate round-bottom flask, $(E)$-ethyl $\beta$-iodoacrylate ${ }^{6}$ (1.19 g, $5.61 \mathrm{mmol}, 1.9 \mathrm{eq})$ was dissolved in dry NMP (11 mL) and this solution was drawn up into a dry syringe. The total volume of the iodoacrylate solution was $\sim 12 \mathrm{~mL}$. To the flask containing 39 was then added $2 \mathrm{~mL}$ of the iodoacrylate solution. The syringe with the remaining solution of the iodoacrylate was placed in a syringe pump apparatus. To the flask containing 39 was then quickly added $\mathrm{CuTc}^{7}(1.11 \mathrm{~g}, 5.82 \mathrm{mmol})$ in a single portion, under positive nitrogen pressure (to exclude oxygen and moisture). Immediately, the syringe pump with the syringe containing the iodoacrylate solution was activated and the remaining iodoacrylate solution was 
added at a steady rate to the heterogeneous reaction mixture over $18 \mathrm{~min}$ The resulting mixture was stirred for an additional $10 \mathrm{~min}$ and then diluted with ether. The mixture was then filtered through a pad of neutral alumina with washing. The filtrate was then washed with water (x2), saturated $\mathrm{NaCl}$ solution, dried over $\mathrm{MgSO}_{4}$, filtered, and concentrated. Purification of the crude material by flash chromatography (hexanes/EtOAc $=95 / 5)$ gave $1.43 \mathrm{~g}(85 \%)$ of $\mathbf{4 7}$ as a yellow oil: $[\alpha]_{\mathrm{D}}{ }^{25}=-63.8\left(c 0.50, \mathrm{CHCl}_{3}\right)^{1} \mathrm{H}$ NMR $\left(500 \mathrm{MHz}, \mathrm{CDCl}_{3}\right) \delta 7.23(\mathrm{~d}, J=8.7 \mathrm{~Hz}, 2 \mathrm{H}), 7.19$ (d, $J=15.8 \mathrm{~Hz}, 1 \mathrm{H}), 6.90(\mathrm{~d}, J=8.7 \mathrm{~Hz}, 2 \mathrm{H}), 5.82(\mathrm{~d}, J=15.8 \mathrm{~Hz}, 1 \mathrm{H}), 5.74(\mathrm{~s}, 1 \mathrm{H}), 5.33$ (s, 1H), $4.94(\mathrm{~d}, J=5.9 \mathrm{~Hz}, 1 \mathrm{H}), 4.81(\mathrm{~d}, J=5.9 \mathrm{~Hz}, 1 \mathrm{H}), 4.56(\mathrm{~d}, J=11.7 \mathrm{~Hz}, 1 \mathrm{H}), 4.29$ (d, $J=$ $11.7 \mathrm{~Hz}, 1 \mathrm{H}), 4.10(\mathrm{~m}, 1 \mathrm{H}), 3.85$ (s, 3H), 3.77 (s, 3H), $3.34(\mathrm{~d}, J=3.7 \mathrm{~Hz}, 1 \mathrm{H}), 2.40-2.32(2 \mathrm{H})$, $2.17(\mathrm{~m}, 1 \mathrm{H}), 1.86(\mathrm{~s}, 3 \mathrm{H}), 1.85(\mathrm{~s}, 3 \mathrm{H}), 1.68(\mathrm{~m}, 1 \mathrm{H}), 1.51(\mathrm{~s}, 3 \mathrm{H}), 1.48-1.27(7 \mathrm{H}), 0.91(\mathrm{t}, J=$ $6.8 \mathrm{~Hz}, 3 \mathrm{H}), 0.15(\mathrm{~s}, 9 \mathrm{H}) ;{ }^{13} \mathrm{C} \mathrm{NMR}\left(125 \mathrm{MHz}, \mathrm{CDCl}_{3}\right) \delta$ 167.8, 159.4, 153.1, 150.8, 144.9, 133.0, 130.1, 129.8, 126.7, 115.6, 113.8, 89.4, 83.5, 82.3, 74.4, 71.8, 55.3, 51.4, 44.4, 40.3, 32.2, 21.7, 26.2, 22.8, 22.6, 21.4, 14.0, 12.8, 0.0; IR (thin film) 2953, 1721, 1619, 1515, 1301, 1249, 1060, 1040, $840 \mathrm{~cm}^{-1}$; HRMS (ES) for $\mathrm{C}_{33} \mathrm{H}_{52} \mathrm{O}_{5} \mathrm{SiNa}[\mathrm{M}+\mathrm{Na}]^{+}$calcd. 595.3431, found 595.3435 $\mathrm{m} / \mathrm{z}$.

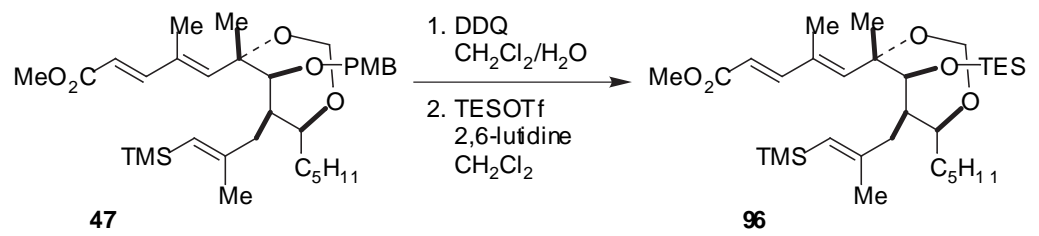

\section{Methyl-(2E,4E,6S,7S,8R,9S)-4,6-dimethyl-6,9-O-methylidene-8-(E-2'-methyl-3'-}

trimethylsilanyl-2'-enyl)-7-[(triethylsilyl)oxy]-tetradeca-2,4-dienoate (96). To a solution of $47(29 \mathrm{mg}, 0.05 \mathrm{mmol})$ in $\mathrm{CH}_{2} \mathrm{Cl}_{2} / \mathrm{H}_{2} \mathrm{O}(1 \mathrm{~mL} / 0.1 \mathrm{~mL})$ at $0{ }^{\circ} \mathrm{C}$ was added DDQ $(17.2 \mathrm{mg}, 0.08$ mmol, 1.5 eq). After $1 \mathrm{~h}$ at $0{ }^{\circ} \mathrm{C}$ and $1 \mathrm{~h}$ at $23{ }^{\circ} \mathrm{C}$, the reaction mixture was diluted with an aqueous saturated solution of $\mathrm{NaHCO}_{3}$. The aqueous layer was extracted with $\mathrm{CH}_{2} \mathrm{Cl}_{2}$, the combined organic layers were washed with saturated $\mathrm{NaCl}$ solution, dried over $\mathrm{MgSO}_{4}$, filtered and concentrated. The crude material was dissolved in $\mathrm{CH}_{2} \mathrm{Cl}_{2}(0.5 \mathrm{~mL})$ and cooled to $0{ }^{\circ} \mathrm{C}$. 2,6- 
Lutidine (18 $\mu \mathrm{L}, 0.15 \mathrm{mmol}, 3 \mathrm{eq})$ was then added, followed by TESOTf ( $23 \mu \mathrm{L}, 0.10 \mathrm{mmol}, 2$ eq). After $30 \mathrm{~min}$ at $0{ }^{\circ} \mathrm{C}$, the reaction mixture was quenched by addition of an aqueous saturated solution of $\mathrm{NaHCO}_{3}$. The aqueous layer was extracted with $\mathrm{CH}_{2} \mathrm{Cl}_{2}$, the combined organic layers were washed with saturated $\mathrm{NaCl}$ solution, dried over $\mathrm{MgSO}_{4}$, filtered and concentrated. Filtration of this material through a pad of silica gel (hexanes / ethyl acetate $=80 / 20$ ) followed by HPLC purification (hexanes / ethyl acetate = 85/15) afforded $22.2 \mathrm{mg}$ (77\% from 47) of 96 as a colorless oil: $[\alpha]_{\mathrm{D}}{ }^{25}=-20.4\left(c 0.93, \mathrm{CHCl}_{3}\right) ;{ }^{1} \mathrm{H} \mathrm{NMR}\left(500 \mathrm{MHz}, \mathrm{CDCl}_{3}\right) \delta 7.33(\mathrm{~d}, J=15.5$ $\mathrm{Hz}, 1 \mathrm{H}), 6.20(\mathrm{~s}, 1 \mathrm{H}), 5.87(\mathrm{~d}, J=15.5 \mathrm{~Hz}, 1 \mathrm{H}), 5.31(\mathrm{~s}, 1 \mathrm{H}), 4.89(\mathrm{~d}, J=6.6 \mathrm{~Hz}, 1 \mathrm{H}), 4.74(\mathrm{~d}, J$ $=6.6 \mathrm{~Hz}, 1 \mathrm{H}), 4.02(\mathrm{~m}, 1 \mathrm{H}), 3.82(\mathrm{~d}, J=4.2 \mathrm{~Hz}, 1 \mathrm{H}), 3.77(\mathrm{~s}, 3 \mathrm{H}), 2.38(\mathrm{dd}, J=14.9$ and 8.6 Hz, 1H), $2.30(\mathrm{dd}, J=14.9$ and $5.6 \mathrm{~Hz}, 1 \mathrm{H}), 1 . .98(\mathrm{~m}, 1 \mathrm{H}), 1.93(\mathrm{~s}, 3 \mathrm{H}), 1.82(\mathrm{~s}, 3 \mathrm{H}), 1.65$ (m, $1 \mathrm{H}), 1.49(\mathrm{~s}, 3 \mathrm{H}), 1.45-1.41(2 \mathrm{H}), 1.36-1.24(5 \mathrm{H}), 0.97(\mathrm{t}, J=8.0 \mathrm{~Hz}, 9 \mathrm{H}), 0.89(\mathrm{t}, J=7.0 \mathrm{~Hz}$, $3 \mathrm{H}), 0.62(\mathrm{q}, J=8.0 \mathrm{~Hz}, 6 \mathrm{H}), 0.12(\mathrm{~s}, 9 \mathrm{H}) ;{ }^{13} \mathrm{C} \mathrm{NMR}\left(125 \mathrm{MHz}, \mathrm{CDCl}_{3}\right) \delta 167.9,153.4,150.8$, $144.0,133.2,125.8,115.8,89.9,83.1,78.8,75.0,51.5,48.6,40.2,32.5,31.8,26.3,25.3,22.6$, 21.8, 14.0, 12.9, 7.0, 5.2, 0.0; IR (thin film) 2955, 1724, 1622, 1300, 1250, 1170, 1070, 1020, $840 \mathrm{~cm}^{-1}$; HRMS (ES) for $\mathrm{C}_{31} \mathrm{H}_{58} \mathrm{O}_{5} \mathrm{Si}_{2} \mathrm{Na}[\mathrm{M}+\mathrm{Na}]^{+}$calcd. 589.3721 , found $589.3727 \mathrm{~m} / z$.

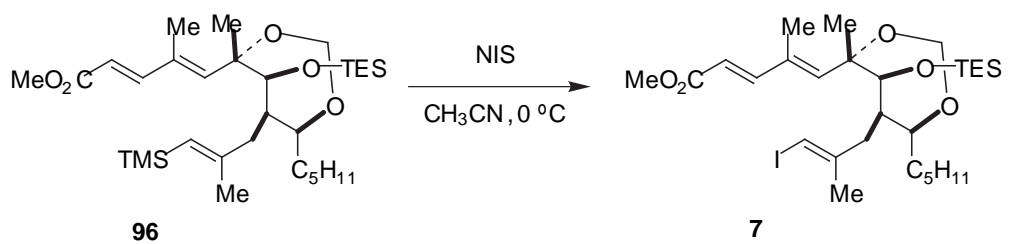

\section{Methyl-(2E,4E,6S,7S,8R,9S)-4,6-dimethyl-6,9-O-methylidene-8-(E-2'-methyl-3'-} iodoprop-2' -enyl)-7-[(triethylsilyl)oxy]-tetradeca-2,4-dienoate (7). To a solution of 96 (1.12 $\mathrm{g}, 1.98 \mathrm{mmol})$ in $\mathrm{CH}_{3} \mathrm{CN}(20 \mathrm{~mL})$ at $0{ }^{\circ} \mathrm{C}$ was added NIS (1.17 $\left.\mathrm{g}, 5.20 \mathrm{mmol}, 2.6 \mathrm{eq}\right)$ in one portion. After $4.5 \mathrm{~h}$ at $0{ }^{\circ} \mathrm{C}$, the reaction mixture was diluted ether and washed with $10 \% \mathrm{Na}_{2} \mathrm{~S}_{2} \mathrm{O}_{3}$ solution (x3). The organic phase was then washed with saturated $\mathrm{NaCl}$ solution, dried over $\mathrm{Na}_{2} \mathrm{SO}_{4}$, filtered, and concentrated to give pure $7(1.18 \mathrm{~g}, 96 \%)$ as a yellow oil. 


\section{Synthesis of Formamicinone (2).}

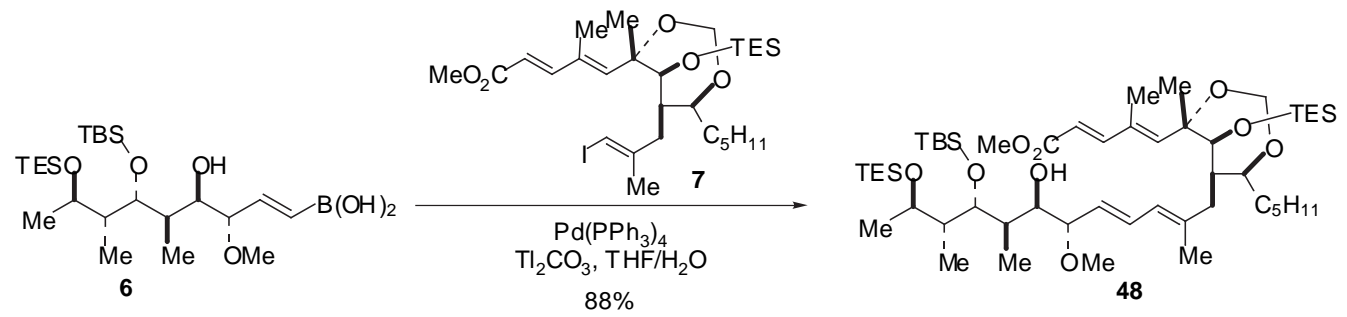

\section{Methyl-(6S,7S,8R,9S)-4,6-dimethyl-6,9-O-methylidene-8-\{(1'E-}

$\left.3^{\prime} E, 5^{\prime} S, 6^{\prime} R, 7^{\prime} R, 8^{\prime} R, 9^{\prime} R, 10^{\prime} R\right)-8^{\prime}$-[(tert-butyldimethylsilyl)oxy]-10'-[(triethylsilyl)oxy-)]-6'(hydroxy)-[1',7',9'-trimethyl]-5'-(methoxy)-undeca-1',3'-diene $\}-7-[($ triethylsilyl)oxy]-icoso-

2,4,10,12-tetraenoate (48): The vinyl boronic acid $\mathbf{6}^{8,9}(291 \mathrm{mg}, 0.577 \mathrm{mmol})$ and vinyl iodide 7 (233 mg, $0.375 \mathrm{mmol}$ ) were combined in $3.6 \mathrm{~mL}$ of degassed THF/ $\mathrm{H}_{2} \mathrm{O}(3: 1 \mathrm{v} / \mathrm{v})$. The reaction was treated sequentially with $\mathrm{Pd}\left(\mathrm{PPh}_{3}\right)_{4}(73 \mathrm{mg}, 0.063 \mathrm{mmol})$, and $\mathrm{Tl}_{2} \mathrm{CO}_{3}(581 \mathrm{mg}, 1.24 \mathrm{mmol})$ and the mixture stirred at $23{ }^{\circ} \mathrm{C}$. After $3 \mathrm{~h}$, additional $\mathrm{Pd}\left(\mathrm{Ph}_{3} \mathrm{P}\right)_{4}(30 \mathrm{mg}, 0.026 \mathrm{mmol})$, and $\mathrm{Tl}_{2} \mathrm{CO}_{3}(110 \mathrm{mg}, 0.24 \mathrm{mmol})$ were added and the reaction stirred for $1.5 \mathrm{~h}$, at which time TLC analysis indicated the reaction was complete. The reaction mixture was diluted with $\mathrm{Et}_{2} \mathrm{O} /$ hexanes $(1: 1)$, filtered through Celite ${ }^{\circledR}$ to remove salts, and the residue concentrated. Purification of this crude product by column chromatography (5:95 EtOAc/hexanes) provided $315 \mathrm{mg}(88 \%)$ of 48: $[\alpha]^{26}{ }_{\mathrm{D}}-21.2\left(c 0.92, \mathrm{CHCl}_{3}\right) ;{ }^{1} \mathrm{H} \mathrm{NMR}\left(\mathrm{CDCl}_{3}, 500 \mathrm{MHz}\right) \delta 7.26(\mathrm{~d}, J=$ $14.3 \mathrm{~Hz}, 1 \mathrm{H}), 6.45(\mathrm{dd}, J=15.1,10.7 \mathrm{~Hz}, 1 \mathrm{H}), 6.21(\mathrm{~s}, 1 \mathrm{H}), 5.99(\mathrm{~d}, J=10.7 \mathrm{~Hz}, 1 \mathrm{H}), 5.83(\mathrm{~d}, J$ $=15.6 \mathrm{~Hz}, 1 \mathrm{H}), 5.56(\mathrm{dd}, J=15.1,8.1 \mathrm{~Hz}, 1 \mathrm{H}), 4.91(\mathrm{~A}$ of $\mathrm{AB}, J=6.5 \mathrm{~Hz}, 1 \mathrm{H}), 4.76(\mathrm{~B}$ of $\mathrm{AB}, J$ $=6.5 \mathrm{~Hz}, 1 \mathrm{H}), 4.00(\mathrm{dd}, J=9.2,2.00 \mathrm{~Hz}, 1 \mathrm{H}), 3.92(\mathrm{~d}, J=8.1 \mathrm{~Hz}, 1 \mathrm{H}), 3.82$ to $3.72(\mathrm{~m}, 3 \mathrm{H})$, 3.75 (s, 3H), 3.49, (app. t, $J=8.1 \mathrm{~Hz}, 1 \mathrm{H}$ ), 3.35 (s, 1H), 3.25 (s, 3H), 2.34 (dd, $J=14.4,8.8 \mathrm{~Hz}$, 1H), $2.24(\mathrm{dd}, J=14.4,4.6 \mathrm{~Hz}, 1 \mathrm{H}), 2.01$ to $1.95(\mathrm{~m}, 1 \mathrm{H}), 1.93$ to $1.80(\mathrm{~m}, 2 \mathrm{H}), 1.91(\mathrm{~s}, 3 \mathrm{H})$, $1.79(\mathrm{~s}, 3 \mathrm{H}), 1.70$ to $1.60(\mathrm{~m}, 1 \mathrm{H}), 1.51(\mathrm{~s}, 3 \mathrm{H}), 1.48$ to $1.38(\mathrm{~m}, 1 \mathrm{H}), 1.38$ to $1.20(\mathrm{~m}, 6 \mathrm{H}), 1.05$ (d, $J=6.1 \mathrm{~Hz}, 3 \mathrm{H}), 1.01(\mathrm{~d}, J=7.1 \mathrm{~Hz}, 3 \mathrm{H}), 0.99$ to $0.85(\mathrm{~m}, 18 \mathrm{H}), 0.89(\mathrm{~s}, 12 \mathrm{H}), 0.88$ (t, $J=$ 
$3.2 \mathrm{~Hz}, 3 \mathrm{H}), 0.64$ to $0.55(\mathrm{~m}, 12 \mathrm{H}), 0.10(\mathrm{~s}, 3 \mathrm{H}), 0.08(\mathrm{~s}, 3 \mathrm{H}) ;{ }^{13} \mathrm{C} \mathrm{NMR}\left(\mathrm{CDCl}_{3}, 125 \mathrm{MHz}\right)$ $\delta 167.9,150.7,143.7,137.1,133.4,130.6,129.8,126.7,115.8,89.9,83.2,82.3,79.5,78.8,77.2$, 74.9, 73.5, 70.1, 55.9, 51.5, 49.1, 44.3, 37.6, 37.6, 32.8, 31.7, 26.2, 25.5, 22.6, 19.9, 18.3, 16.9, 14.0, 12.9, 11.7, 11.6, 7.0, 6.9, 5.2, -3.5, -3.7; IR (neat) 2956, 2878, 1724, 1623, 1463, 1298, 1253, 1170, 1075, 1017, 837, 774, $742 \mathrm{~cm}^{-1}$; HRMS (FAB+) for $\mathrm{C}_{52} \mathrm{H}_{100} \mathrm{O}_{9} \mathrm{NaSi}_{3}[\mathrm{M}+\mathrm{Na}]^{+}$ calcd. 975.6573 , found $975.6527 \mathrm{~m} / \mathrm{z}$.
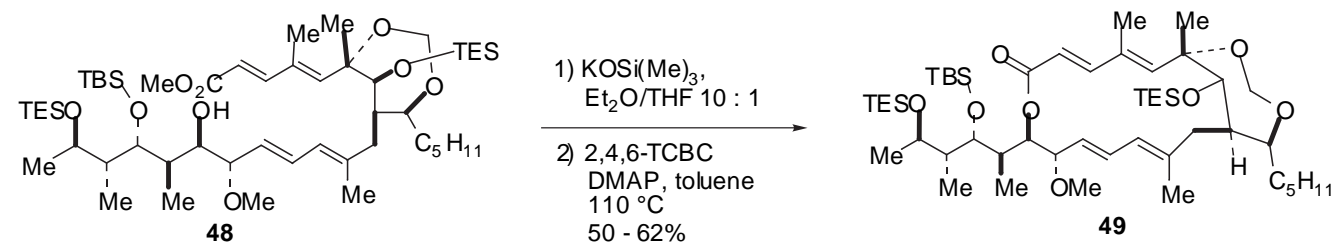

$(1 S, 2 E, 4 E, 8 R, 9 S, 10 E, 12 E, 15 R, 16 S, 20 S)-8-\left[\left(1^{\prime} R, 2^{\prime} R, 3^{\prime} S, 6^{\prime} R, 7^{\prime} S, 8^{\prime} R\right)-2^{\prime}, 7^{\prime}-[\operatorname{di}(t e r t-\right.$

Butyldimethylsilyl)oxy]-4'-[(triethylsilyl)oxy]-(1',3',dimethyl)-pentyl]-20-[(triethylsilyl)oxy]9-methoxy-1,3,13-trimethyl-16-pentyl-7,17,19-trioxabicyclo[13.4.1] eicosa-2,4,10,12tetraene-6-one (49).

Deprotection of the methyl ester: To a solution of ester 48 (130 mg, $0.14 \mathrm{mmol})$ in $\mathrm{Et}_{2} \mathrm{O} / \mathrm{THF}(5.5 \mathrm{~mL}, 10: 1)$ was added $\mathrm{KOSi}(\mathrm{Me})_{3}(39 \mathrm{mg}, 0.30 \mathrm{mmol})$ and this mixture was stirred for $24 \mathrm{~h}$ at $23{ }^{\circ} \mathrm{C}$. The reaction was diluted with EtOAc $(25 \mathrm{~mL})$ and $\mathrm{H}_{2} \mathrm{O}(5 \mathrm{~mL})$, and the biphasic mixture stirred vigorously for 5 min The organic layer was separated and the aqueous was made acidic by the addition of $1 \mathrm{~N} \mathrm{HCl}(500 \mu \mathrm{L})$, and further extracted with EtOAc. The combined organic solution was washed with saturated $\mathrm{NaCl}$ solution, dried over $\mathrm{Na}_{2} \mathrm{SO}_{4}$, filtered and concentrated in vacuo to provide $126 \mathrm{mg}$ of the crude acid which was used in the next step without further purification.

Macrolactonization procedure A: The crude acid (126 $\mathrm{mg}, 0.14 \mathrm{mmol}$ ) was azeotropically dried by concentration from benzene $(3 \mathrm{x})$ on a rotary evaporator. The residue was dissolved in $3 \mathrm{~mL}$ of THF and treated sequentially with $i$ - $\operatorname{Pr}_{2} \mathrm{NEt}(356 \mu \mathrm{L}, 2.1 \mathrm{mmol})$ and 2,4,6trichlorobenzoylchloride (TCBC) $(174 \mu \mathrm{L}, 1.1 \mathrm{mmol})$, and the reaction stirred at $23{ }^{\circ} \mathrm{C}$ for $2 \mathrm{~h}$. 
The reaction mixture was concentrated in vасио and the residue was dissolved in $1.5 \mathrm{~mL}$ of toluene, and added to a solution of 4-dmimethylaminopyridine (DMAP) (166 mg $1.36 \mathrm{mmol}$ ), followed by $2 \mathrm{~mL}$ of toluene rinse. The reaction was heated to reflux for $13 \mathrm{~h}$, cooled to $23{ }^{\circ} \mathrm{C}$ and filtered. The filtrate was diluted with $\mathrm{Et}_{2} \mathrm{O}$ and washed with $\mathrm{H}_{2} \mathrm{O}$, saturated $\mathrm{NaCl}$ solution, dried over $\mathrm{Na}_{2} \mathrm{SO}_{4}$, filtered and concentrated in vacuo. The residue was purified by column chromatography (10 g of Davisil, 2\% - 5\% EtOAc/hexanes) followed by HPLC (21 mm column, 5\% EtOAc/hexanes) to provide $78 \mathrm{mg}(62 \%)$ of 49.

Macrolactonization procedure B: To the crude acid $(0.0357 \mathrm{mmol})$ in dry toluene $(16$ $\mathrm{mL}$ ) under nitrogen was added DMAP (69 mg, $0.566 \mathrm{mmol}$ ) followed by TCBC (56 $\mu \mathrm{L}, 0.358$ mmol). A white precipitate formed immediately. The heterogeneous mixture was heated to 110 ${ }^{\circ} \mathrm{C}$ for $12 \mathrm{~h}$. The reaction mixture was cooled to ambient temperature, diluted with ether, and washed with water followed by saturated $\mathrm{NaCl}$ solution. The solution was dried over $\mathrm{Na}_{2} \mathrm{SO}_{4}$, filtered and concentrated. Purification of the crude product by preparative TLC (5\% EtOAc/hexanes) provided 49 as a clear oil $(17 \mathrm{mg}, 52 \%):[\alpha]_{\mathrm{D}}^{26}-2.3\left(c 0.78, \mathrm{CHCl}_{3}\right),{ }^{1} \mathrm{H} \mathrm{NMR}$ $\left(\mathrm{CDCl}_{3}, 500 \mathrm{MHz}\right) \delta 7.10(\mathrm{~d}, J=15.6 \mathrm{~Hz}, 1 \mathrm{H}), 6.49(\mathrm{dd}, J=14.9,10.7 \mathrm{~Hz}, 1 \mathrm{H}), 5.8(\mathrm{~d}, J=$ $10.7 \mathrm{~Hz}, 1 \mathrm{H}), 5.70(\mathrm{~d}, J=15.8 \mathrm{~Hz}, 1 \mathrm{H}) 5.65(\mathrm{~s}, 1 \mathrm{H}), 5.22(\mathrm{dd}, J=14.9,8.6 \mathrm{~Hz}, 1 \mathrm{H}), 5.02(\mathrm{dd}, J$ $=7.6,4.6 \mathrm{~Hz}, 1 \mathrm{H}), 4.76(\mathrm{~d}, J=8.8 \mathrm{~Hz}, 1 \mathrm{H}), 4.68(\mathrm{~d}, J=8.8 \mathrm{~Hz}, 1 \mathrm{H}), 3.96($ app. $\mathrm{t}, J=3.4 \mathrm{~Hz}$, 1H), 3.88 (app. t, $J=8.1 \mathrm{~Hz}, 1 \mathrm{H}), 3.83(\operatorname{app~t}, J=6.4 \mathrm{~Hz}, 1 \mathrm{H}), 3.79$ (d, $J=7.3 \mathrm{~Hz}, 1 \mathrm{H}), 3.64$ to $3.58(\mathrm{~m}, 1 \mathrm{H}), 3.24(\mathrm{~s}, 3 \mathrm{H}), 2.67(\mathrm{dd}, J=7.3,6.9 \mathrm{~Hz}, 1 \mathrm{H}), 2.09$ to $2.02(\mathrm{~m}, 1 \mathrm{H}), 1.99(\mathrm{dd}, J=$ 9.0, 4.9 Hz, 1H), $1.96(\mathrm{~s}, 3 \mathrm{H}), 1,95(\mathrm{~d}, J=8.3,1 \mathrm{H}), 1.92$ to $1.85(\mathrm{~m}, 1 \mathrm{H}), 1.86(\mathrm{~s}, 3 \mathrm{H}), 1.65$ to $1.55(\mathrm{~m}, 1 \mathrm{H}), 1.40$ to $1.20(\mathrm{~m}, 7 \mathrm{H}), 1.39(\mathrm{~s}, 3 \mathrm{H}), 1.10(\mathrm{~d}, J=6.4 \mathrm{~Hz}, 3 \mathrm{H}), 1.02(\mathrm{t}, J=8.1 \mathrm{~Hz}$, $12 \mathrm{H}), 0.95$ (t, $J=7.8 \mathrm{~Hz}, 9 \mathrm{H}), 0.88$ (t, $J=3.4 \mathrm{~Hz}, 3 \mathrm{H}), 0.88(\mathrm{~s}, 12 \mathrm{H}), 0.81$ to $0.69(\mathrm{~m}, 6 \mathrm{H}), 0.61$ $(\mathrm{q}, J=7.8 \mathrm{~Hz}, 6 \mathrm{H}), 0.09(\mathrm{~s}, 3 \mathrm{H}), 0.07(\mathrm{~s}, 3 \mathrm{H}) ;{ }^{13} \mathrm{C} \mathrm{NMR}\left(\mathrm{CDCl}_{3}, 125 \mathrm{MHz}\right) \delta 166.7,150.8$, $142.2,141.2,134.4,131.6,128.2,125.1,116.5,86.4,85.4,81.2,78.6,75.5,74.9,73.2,70.3$, 55.7, 47.4, 43.1, 42.6, 34.2, 31.9, 30.2, 26.1, 25.9, 25.5, 22.6, 20.1, 20.0, 18.5, 14.1, 12.0, 11.5, $10.2,7.3,7.1,5.7,5.3,-3.6,-4.1$; IR (neat) 2957, 2878, 1713, 1461, 1373, 1253, 1089, 1018, 
967, 869, 835, 773, 736, $674 \mathrm{~cm}^{-1}$; HRMS (FAB+) for $\mathrm{C}_{51} \mathrm{H}_{58} \mathrm{O}_{4} \mathrm{NaSi}_{3}[\mathrm{M}+\mathrm{Na}]^{+}$calcd. 943.6310, found $943.6318 \mathrm{~m} / \mathrm{z}$.
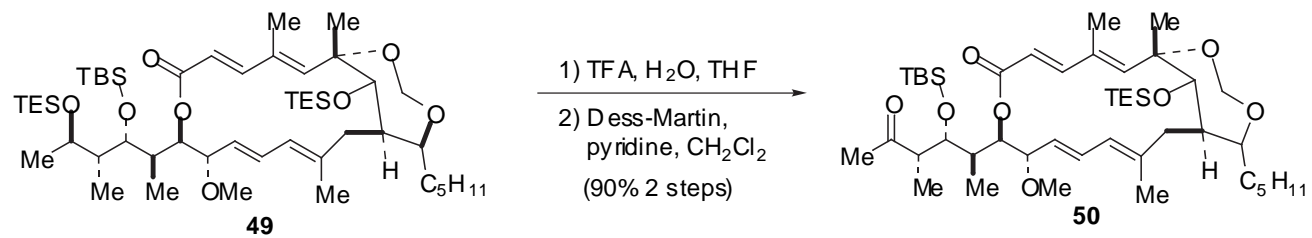

$(1 S, 2 E, 4 E, 8 R, 9 S, 10 E, 12 E, 15 R, 16 S, 20 S)-8-\left[\left(1^{\prime} R, 2^{\prime} R, 3^{\prime} S, 6^{\prime} R, 7^{\prime} S, 8^{\prime} R\right)-2^{\prime}, 7^{\prime}-\operatorname{di}(t e r t-\right.$

Butyldimethylsilyl)oxy-(1',3'-dimethyl)-pent-4' -one]-20-[(trimethylsilyl)oxy]-9-methoxy1,3,13-trimethyl-16-pentyl-7,17,19-trioxabicyclo[13.4.1] eicosa-2,4,10,12-tetraene-6-one (50). A solution of the macrolactone $49(78 \mathrm{mg}, 0.085 \mathrm{mmol})$ in $\mathrm{THF}(2.5 \mathrm{~mL})$ was cooled to $0{ }^{\circ} \mathrm{C}$ and a solution of TFA $\left(212 \mu \mathrm{L}, 4.0 \mathrm{M}\right.$ in $\left.\mathrm{H}_{2} \mathrm{O}\right)$ was added. The reaction was stirred for 150 min until complete by TLC analysis (20\% ethyl acetate/hexanes). The reaction was diluted with $15 \mathrm{~mL}$ of $\mathrm{Et}_{2} \mathrm{O}$ and washed with $\mathrm{NaHCO}_{3}(3 \times 2 \mathrm{~mL})$, dried over $\mathrm{MgSO}_{4}$, filtered, and concentrated on the rotary evaporator followed by high vacuum to give $72 \mathrm{mg}$ (>99\%) of crude alcohol which was $>95 \%$ pure by ${ }^{1} \mathrm{H}-\mathrm{NMR}$.

A solution of the crude alcohol $(72 \mathrm{mg}, 0.085 \mathrm{mmol})$ in $\mathrm{CH}_{2} \mathrm{Cl}_{2}(3.0 \mathrm{~mL})$ at $0{ }^{\circ} \mathrm{C}$ was treated with pyridine $(34 \mu \mathrm{L}, 0.42 \mathrm{mmol})$, followed by Dess-Martin periodinane $(72 \mathrm{mg}, 0.17$ mmol). The reaction stirred at $0{ }^{\circ} \mathrm{C}$ for $2 \mathrm{~h}$. TLC analysis ( $20 \%$ ethyl acetate/hexanes) at this point showed the reaction to be approximately $70 \%$ complete. Additional pyridine $(68 \mu \mathrm{L}, 0.84$ $\mathrm{mmol})$ and Dess-Martin periodinane $(72 \mathrm{mg}, 0.17 \mathrm{mmol})$ were added and the reaction stirred until complete by TLC analysis $(4 \mathrm{~h})$. The reaction mixture was diluted with $\mathrm{Et}_{2} \mathrm{O}(20 \mathrm{~mL})$ and washed $(3 \times 2 \mathrm{~mL})$ with a $1: 1(\mathrm{v}: \mathrm{v})$ mixture of satd. $\mathrm{Na}_{2} \mathrm{~S}_{2} \mathrm{O}_{3}$ and satd. $\mathrm{NaHCO}_{3}$, dried over $\mathrm{MgSO}_{4}$, filtered, and concentrated on the rotary evaporator. The crude residue was purified on a Davisil $^{\circledR}$ column $(5.0 \mathrm{~g})$ eluted with a gradient of ethyl acetate/hexanes (5-20\%) to yield $61 \mathrm{mg}$ (90\% from macrolactone 49) of the methyl ketone 50: $[\alpha]^{23}{ }_{\mathrm{D}}+13.4\left(c \text { 1.65, } \mathrm{CHCl}_{3}\right)^{1} \mathrm{H} \mathrm{NMR}$ $\left(\mathrm{CDCl}_{3}, 500 \mathrm{MHz}\right) \delta 7.13(\mathrm{~d}, J=15.9 \mathrm{~Hz}, 1 \mathrm{H}), 6,48(\mathrm{dd}, J=15.1,11.0 \mathrm{~Hz}, 1 \mathrm{H}), 5.78(\mathrm{~d}, J=$ 
$11.0 \mathrm{~Hz}, 1 \mathrm{H}), 5.72(\mathrm{~d}, J=15.9 \mathrm{~Hz}, 1 \mathrm{H}), 5.66(\mathrm{~s}, 1 \mathrm{H}), 5.14(\mathrm{dd}, J=15.1,9.5 \mathrm{~Hz}, 1 \mathrm{H}), 4.91(\mathrm{dd}, J$ $=7.8,5.6 \mathrm{~Hz}, 1 \mathrm{H}), 4.77(\mathrm{~d}, J=8.5 \mathrm{~Hz}, 1 \mathrm{H}), 4.70(\mathrm{~d}, J=8.5 \mathrm{~Hz}, 1 \mathrm{H}), 4.30($ app. $\mathrm{t}, J=3.7 \mathrm{~Hz}$, 1H), 3.80 (d, $J=7.3 \mathrm{~Hz}, 1 \mathrm{H}), 3.70$ (d, $J=8.8 \mathrm{~Hz}, 1 \mathrm{H}) 3.61$ (app. t, $J=7.6 \mathrm{~Hz}, 1 \mathrm{H}), 3.19$ (s, 3H), 2.95 (ddd, $J=11.0,10.3,3.2 \mathrm{~Hz}, 1 \mathrm{H}), 2,75$ to $2.64(\mathrm{~m}, 1 \mathrm{H}), 2.18,(\mathrm{~s}, 3 \mathrm{H}), 2.04$ to 1.90 (m, 2H), $1.98(\mathrm{~s}, 3 \mathrm{H}), 1.88(\mathrm{~s}, 3 \mathrm{H}), 1.64$ to $1.56(\mathrm{~m}, 1 \mathrm{H}), 1.38(\mathrm{~s}, 3 \mathrm{H}), 1.38$ to $1.22(\mathrm{~m}, 8 \mathrm{H}), 1.13(\mathrm{~d}$, $J=7.1 \mathrm{~Hz}, 3 \mathrm{H}), 1.02(\mathrm{~d}, J=7.8 \mathrm{~Hz}, 3 \mathrm{H}), 1.00(\mathrm{t}, J=5.6 \mathrm{~Hz}, 9 \mathrm{H}), 0.89(\mathrm{t}, J=6.8 \mathrm{~Hz}, 3 \mathrm{H}), 0.88$ (s, 9H), 0.81 to $0.70(\mathrm{~m}, 6 \mathrm{H}), 0.15(\mathrm{~s}, 3 \mathrm{H}), 0.09(\mathrm{~s}, 3 \mathrm{H}) \quad \delta 211.8,166.9,151.2,142.7,141.8$, 134.3, 132.1, 127.8, 125.0, 116.1, 86.4, 81.2, 78.6, 75.5, 74.7, 71.8, 55.6, 48.7, 47.4, 43.8, 34.2, $31.9,30.2,29.7,29.1,26.0,25.8,25.5,22.6,20.2,18.3,14.1,12.5,12.0,11.0,7.3,5.7,-4.2,-4.3$; IR (thin film, $\mathrm{CHCl}_{3}$ ) 2956, 2930, 2878, 2857, 1709, 1462, 1369, 1359, 1252, 1173, 1089, 1024, 869, 829, 774, $738 \mathrm{~cm}^{-1}$; HRMS (ES) for $\mathrm{C}_{45} \mathrm{H}_{80} \mathrm{O}_{8} \mathrm{Si}_{2} \mathrm{Na}[\mathrm{M}+\mathrm{Na}]^{+}$calcd. 827.5289, found $827.5301 \mathrm{~m} / \mathrm{z}$.

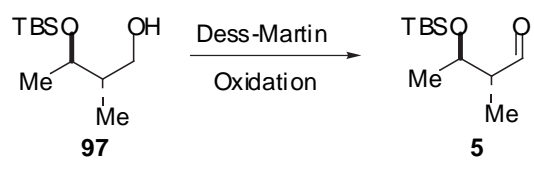

(2S,3R)-3-(tert-Butyl-dimethyl-silanyloxy)-2-methyl-butyraldehyde (5): To a solution of alcohol $97^{10}(0.5 \mathrm{~g}, 2.29 \mathrm{mmol})$ in $\mathrm{CH}_{2} \mathrm{Cl}_{2}(15 \mathrm{~mL})$ and pyridine $(0.26 \mathrm{~mL}, 3.2 \mathrm{mmol})$ at $23^{\circ} \mathrm{C}$ was added the Dess-Martin periodinane reagent $(1.16 \mathrm{~g}, 2.75 \mathrm{mmol})$. A solution of wet $\mathrm{CH}_{2} \mathrm{Cl}_{2}$ ( $8 \mathrm{~mL}$ of dry $\mathrm{CH}_{2} \mathrm{Cl}_{2}$ and $30 \mu \mathrm{L}$ of $\mathrm{H}_{2} \mathrm{O}$ ) was then added dropwise over $30 \mathrm{~min}$ The resulting solution was concentrated to $\sim 2 \mathrm{~mL}$ and $\mathrm{Et}_{2} \mathrm{O}(10 \mathrm{~mL})$ was added. The organic layer was washed successively with a saturated aqueous solution of $\mathrm{Na}_{2} \mathrm{~S}_{2} \mathrm{O}_{3}(3 \mathrm{~mL})$, a saturated aqueous solution of $\mathrm{NaHCO}_{3}(3 \mathrm{~mL})$ and water $(10 \mathrm{~mL})$. The combined aqueous layers were back-extracted with $\mathrm{Et}_{2} \mathrm{O}$, washed with saturated $\mathrm{NaCl}$ solution, dried over $\mathrm{MgSO}_{4}$, filtered and concentrated under reduced pressure. The crude oil was dissolved in pentane and filtered through a plug of Celite ${ }^{\circledR}$. After evaporation of the solvent, the aldehyde $\mathbf{5}$ was obtained as a slightly yellow oil and was used in the next step without purification. 

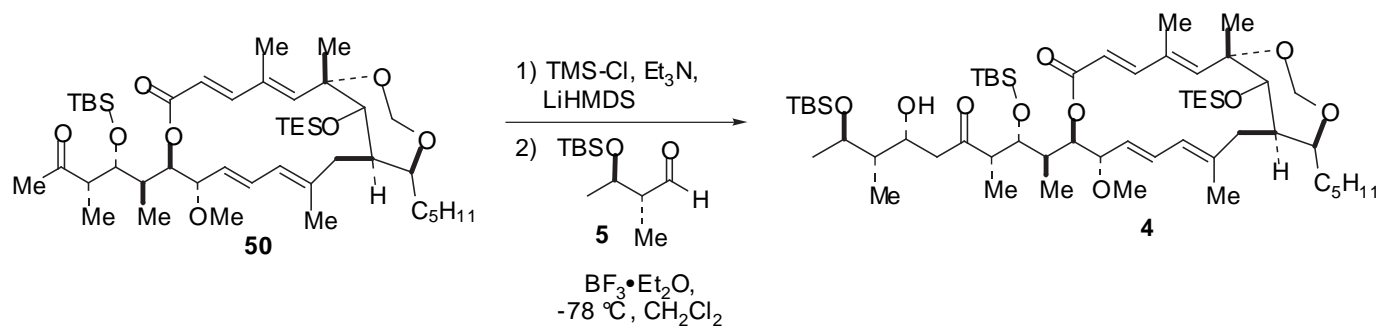

\section{$(1 S, 2 E, 4 E, 8 R, 9 S, 10 E, 12 E, 15 R, 16 S, 20 S)-8-\left[\left(1^{\prime} R, 2^{\prime} R, 3^{\prime} S, 6^{\prime} R, 7^{\prime} S, 8^{\prime} R\right)-2^{\prime}, 7^{\prime}-\operatorname{di}(t e r t-\right.$}

\section{Butyldimethylsilyl)oxy-(1',3',7'-trimethyl)-non-4' -one $]-20-[($ trimethylsilyl)oxy $]-9-m e t h o x y-$}

\section{1,3,13-trimethyl-16-pentyl-7,17,19-trioxabicyclo[13.4.1] eicosa-2,4,10,12-tetraene-6-one (4):}

A solution of the methyl ketone $\mathbf{5 0}(80 \mathrm{mg}, 0.099 \mathrm{mmol})$ in THF $(1 \mathrm{~mL})$ was cooled to $-78{ }^{\circ} \mathrm{C}$ and treated with a 1:1 (v:v) mixture of $\mathrm{Et}_{3} \mathrm{~N}$ and $\mathrm{TMS}-\mathrm{Cl}(200 \mu \mathrm{L}$, premixed under nitrogen and aged for $10 \mathrm{~min}$ ), stirred for $10 \mathrm{~min}$ and then treated with LiHMDS (1.0M in THF, $320 \mu \mathrm{L}, 0.320$ mmol). The solution was stirred for $30 \mathrm{~min}$ and then quenched by the addition of cold $\mathrm{pH} 7$ buffer $(300 \mu \mathrm{L})$ and diluted with 1:1 Et $\mathrm{E}_{2} \mathrm{O}$ /pentane. The layers were separated and the aqueous phase extracted with 1:1 Et ${ }_{2} \mathrm{O} /$ pentane (x 2). The organic extracts were combined, dried over $\mathrm{Na}_{2} \mathrm{SO}_{4}$, filtered and concentrated. The residue was diluted with benzene and reconcentrated two times to give the crude enol silane.

To this material was added a solution of aldehyde $5^{10}(200 \mathrm{mg}, 0.924 \mathrm{mmol})$ in dry benzene and the resulting mixture was concentrated on the rotary evaporator. The mixture was then dried under high vacuum $(<0.7 \mathrm{~mm}$ of $\mathrm{Hg})$ for $30 \mathrm{sec}$ (Note: aldehyde $\mathbf{5}$ is volatile). The residue was then dissolved in dry $\mathrm{CH}_{2} \mathrm{Cl}_{2}(450 \mu \mathrm{L})$ under nitrogen atmosphere. To the solution were then added $4 \AA$ MS (powdered and freshly activated by heating under vacuum) and the resulting mixture was stirred at $23{ }^{\circ} \mathrm{C}$ for $10 \mathrm{~min}$ The heterogeneous mixture was cooled to -78 ${ }^{\circ} \mathrm{C}$ and $\mathrm{BF}_{3} \cdot \mathrm{OEt}_{2}\left(95 \mu \mathrm{L}, 1.0 \mathrm{M}\right.$ in $\left.\mathrm{CH}_{2} \mathrm{Cl}_{2}, 0.095 \mathrm{mmol}\right)$ was added such that the solution was cooled by running down the side of the flask. After $80 \mathrm{~min}$, the reaction was quenched with saturated $\mathrm{NaHCO}_{3}$ solution and warmed to ambient temperature. The layers were separated and the aqueous phase was extracted with $\mathrm{Et}_{2} \mathrm{O}$. The organic phases were combined, dried over 
$\mathrm{Na}_{2} \mathrm{SO}_{4}$, filtered, and concentrated on the rotary evaporator. ${ }^{1} \mathrm{H} \mathrm{NMR}$ analysis of the crude reaction mixture showed the diastereoselectivity to be $>95: 5$. The residue was purified by column chromatography (Davisil ${ }^{\mathrm{TM}} \mathrm{pH}=7 \mathrm{SiO}_{2}, 5 \%$ to $10 \%$ EtOAc/hexanes) to provide $88 \mathrm{mg}$ of the desired Felkin aldol 4 (86\%): $[\alpha]_{\mathrm{D}}^{26}+18.8$ (c 0.98, benzene); ${ }^{1} \mathrm{H}$ NMR $\left(\mathrm{C}_{6} \mathrm{H}_{6}, 500 \mathrm{MHz}\right) \delta$ 7.40, (d, $J=16.7 \mathrm{~Hz}, 1 \mathrm{H}), 6.64,(\mathrm{dd}, J=14.9,10.7 \mathrm{~Hz}, 1 \mathrm{H}), 5.92,(\mathrm{~d}, J=16.7 \mathrm{~Hz}, 1 \mathrm{H}), 5.80,(\mathrm{~d}$, $J=10.7 \mathrm{~Hz}, 1 \mathrm{H}), 5.77,(\mathrm{~s}, 1 \mathrm{H}), 5.43,(\mathrm{dd}, J=15.1,9.3 \mathrm{~Hz}, 1 \mathrm{H}), 5.42,(\mathrm{dd}, J=8.3,8.0 \mathrm{~Hz}, 1 \mathrm{H})$, 4.81, (ddd, $J=9.3,5.1,2.4 \mathrm{~Hz}, 1 \mathrm{H}), 4.73,(\mathrm{~d}, J=8.5 \mathrm{~Hz}, 1 \mathrm{H}), 4.68(\mathrm{dd}, J=4.6,3.2 \mathrm{~Hz}, 1 \mathrm{H})$, $4.42\left(\mathrm{~A}\right.$ of $\left.\mathrm{AB}, \mathrm{J}_{\mathrm{AB}}=8.6 \mathrm{~Hz}, 1 \mathrm{H}\right), 3.95$, $\left(\mathrm{B}\right.$ of $\left.\mathrm{AB}, \mathrm{J}_{\mathrm{AB}}=8.6 \mathrm{~Hz}, 1 \mathrm{H}\right), 3.90-3.82,(\mathrm{M}, 2 \mathrm{H}), 3.54$, $(\mathrm{dd}, J=9.0,6.6 \mathrm{~Hz}, 1 \mathrm{H}), 3.32,(\mathrm{~d}, J=2.2 \mathrm{~Hz}, 1 \mathrm{H}), 3.21,(\mathrm{~s}, 3 \mathrm{H}), 3.18-3.10,(\mathrm{~m}, 1 \mathrm{H}), 2.84,(\mathrm{~A}$ of $\left.\mathrm{ABX}, \mathrm{J}_{\mathrm{AB}}=17.1 \mathrm{~Hz}, \mathrm{~J}_{\mathrm{AX}}=9.5 \mathrm{~Hz}, 1 \mathrm{H}\right), 2.66$, (app. q, $\left.J=7.3 \mathrm{~Hz}, 1 \mathrm{H}\right), 2.56,\left(\mathrm{~B}\right.$ of $\mathrm{ABX}, \mathrm{J}_{\mathrm{AB}}=$ $\left.17.1 \mathrm{~Hz}, \mathrm{~J}_{\mathrm{BX}}=2.9 \mathrm{~Hz}, 1 \mathrm{H}\right), 2.34-2.26,(\mathrm{~m}, 1 \mathrm{H}), 1.99,(\mathrm{~s}, 3 \mathrm{H}), 1.92-1.80,(\mathrm{~m}, 3 \mathrm{H}), 1.72,(\mathrm{~s}$, $3 \mathrm{H}), 1.60-1.50,(\mathrm{~m}, 1 \mathrm{H}), 1.46(\mathrm{~s}, 3 \mathrm{H}), 1,42-1.30,(\mathrm{~m}, 7 \mathrm{H}), 1.24(\mathrm{~d}, J=7.3 \mathrm{~Hz}, 3 \mathrm{H}), 1.18,(\mathrm{~d}, J$ $=7.1 \mathrm{~Hz}, 3 \mathrm{H}), 1.16,(\mathrm{~d}, J=6.1 \mathrm{~Hz}, 3 \mathrm{H}), 1.08,(\mathrm{~s}, 9 \mathrm{H}), 0.99,(\mathrm{~d}, J=7.1 \mathrm{~Hz}, 3 \mathrm{H}), 0.96,(\mathrm{~s}, 9 \mathrm{H})$, 0.92, (s, 9H), 0.92, (t, $J=8.1 \mathrm{~Hz}, 3 \mathrm{H}), 0.70-0.58$, (m, 6H), 0.34 (s, 3H), 0.29, (s, 3H), 0.12, (s, 3H), 0.04, (s, 3H); ${ }^{13} \mathrm{C}$ NMR $\left(\mathrm{C}_{6} \mathrm{H}_{6}, 125 \mathrm{MHz}\right) \quad \delta 213.5,166.8,151.0,142.5,141.7,134.7$, $132.3,129.0,125.8,116.9,86,9,86.6,81.2,78.5,75.8,75.1,72.5,71.9,66.5,55.7,49.2,47.8$, $47.0,44.9,44.2,34.5,32.2,30.6,26.4,26.2,26.0,25.8,23.0,21.9,20.3,18.7,18.1,14.3,12.6$, 12.0, 11.1, 10.5, 7.4, 6.0, -3.8, -4.0, -4.3, -4.9; IR (thin film, benzene) 2965, 1710, 1460, 1376, 1254, 1087, 1022, 836, 775, 737, $\mathrm{cm}^{-1}$; HRMS (ES) for $\mathrm{C}_{56} \mathrm{H}_{104} \mathrm{O}_{10} \mathrm{Si}_{3} \mathrm{Na}[\mathrm{M}+\mathrm{Na}]^{+}$calcd. 1043.6835, found $1043.6838 \mathrm{~m} / \mathrm{z}$.
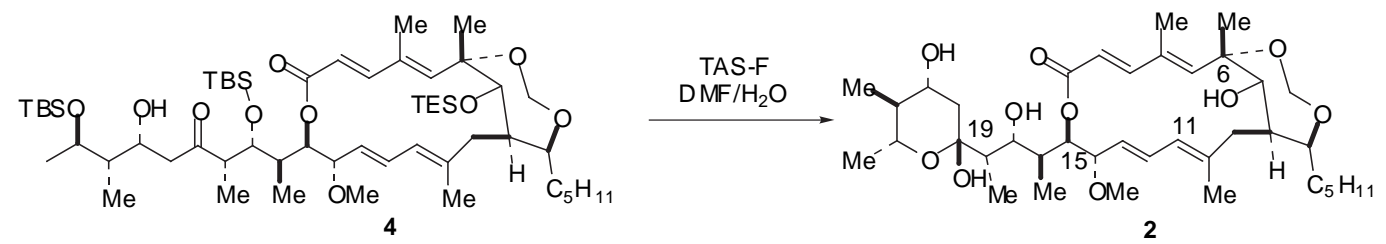
$(1 S, 2 E, 4 E, 8 R, 9 S, 10 E, 12 E, 15 R, 16 S, 20 S)-8-\left[\left(1^{\prime} R, 2^{\prime} R, 3^{\prime} S, 6^{\prime} R, 7^{\prime} S, 8^{\prime} R\right)-3^{\prime}-\right.$ $\left(2 " R, 4^{\prime \prime} R, 5^{\prime \prime} R, 6^{\prime \prime} S\right)-\left(2^{\prime \prime}\right.$, dihydroxy-5",6"-dimethyl-tetrahydropyran-2"-yl)-2'-hydroxy-1'methylbutyl]-20-hydroxy-9-methoxy-1,3,13-trimethyl-16-pentyl-7,17,19-

trioxabicyclo[13.4.1]eicosa-2,4,10,12-tetraene-6-one (Formamicin Aglycon) (2). A solution of TAS-F (9.7mg, $0.035 \mathrm{mmol}$,) and $\mathrm{H}_{2} \mathrm{O}(1.4 \mu \mathrm{L}, 0.078 \mathrm{mmol}$,) in DMF (100 $\mu \mathrm{L})$ was added to a solution of $4(3.6 \mathrm{mg}, 0.0035 \mathrm{mmol})$ in DMF $(50 \mu \mathrm{L})$. The reaction stirred for two hours until only one lower $\mathrm{Rf}$ spot $(\mathrm{Rf}=0.25)$ was present by TLC analysis $(50 \%$ ethyl acetate/hexanes). The reaction was concentrated to approx. $50 \mu \mathrm{L}$ and then loaded directly onto a Davisil ${ }^{\circledR}$ column $(3.0 \mathrm{~g})$ and eluted with a gradient of ethyl acetate/hexanes (25-50\%). In this way, $2.4 \mathrm{mg}$ of a crude white solid was obtained which was further purified by HPLC (10 mm column, 60\% EA/hex) to furnish $1.9 \mathrm{mg}(80 \%)$ of the formamicin aglycon 2 as a white solid: $[\alpha]^{26}{ }_{D}+12.1(c$ 0.19 , benzene); ${ }^{1} \mathrm{H}$ NMR (4 : $\left.1 \mathrm{CDCl}_{3} / \mathrm{C}_{6} \mathrm{H}_{6}, 500 \mathrm{MHz}\right) \delta 7.22,(\mathrm{~d}, J=15.6 \mathrm{~Hz}, 1 \mathrm{H}), 6.48,(\mathrm{dd}, J$ $=14.9,10.7 \mathrm{~Hz}, 1 \mathrm{H}) 5.71(\mathrm{~d}, J=11.0 \mathrm{~Hz}, 1 \mathrm{H}), 5.68(\mathrm{~s}, 1 \mathrm{H}), 5.65,(\mathrm{~d}, J=15.9 \mathrm{~Hz}, 1 \mathrm{H}), 5.64$, $(\mathrm{d}, J=1.2 \mathrm{~Hz}, 1 \mathrm{H}), 5.15(\mathrm{dd}, J=14.9,9.5 \mathrm{~Hz}, 1 \mathrm{H}), 4.91,(\mathrm{~d}, J=9.0 \mathrm{~Hz}, 1 \mathrm{H}), 4.78,(\mathrm{~d}, J=4.1$ $\mathrm{Hz}, 1 \mathrm{H}), 4.68,\left(\mathrm{~A}\right.$ of $\left.\mathrm{AB}, \mathrm{J}_{\mathrm{AB}}=8.7 \mathrm{~Hz}, 1 \mathrm{H}\right), 4.58,\left(\mathrm{~B}\right.$ of $\left.\mathrm{AB}, \mathrm{J}_{\mathrm{AB}}=8.7 \mathrm{~Hz}, 1 \mathrm{H}\right), 4.14,(\mathrm{~m}, J=10.7$, $2.7 \mathrm{~Hz}, 1 \mathrm{H}), 3.86$, (app. t, $J=9.0 \mathrm{~Hz}, 1 \mathrm{H}), 3.70,(\mathrm{~m}, J=12.5,10.0,6.1 \mathrm{~Hz}, 1 \mathrm{H}), 3.63,(\mathrm{~m}, 1 \mathrm{H})$, 3.56, (app. t, $J=7.3 \mathrm{~Hz}, 1 \mathrm{H}), 3.51$, (dd, $J=8.3,5.6 \mathrm{~Hz}, 1 \mathrm{H}$ ), 3.18, (s, 3H), 2.60, (app. q, $J=9.3$ $\mathrm{Hz}, 1 \mathrm{H}), 2.24,(\mathrm{dd}, J=12.0,4,6 \mathrm{~Hz}, 1 \mathrm{H}), 2.14$, (ddd, $J=13.9,10.7,7.1 \mathrm{~Hz}, 1 \mathrm{H}), 1.92,(\mathrm{~d}, J=$ $14.1 \mathrm{~Hz}, 1 \mathrm{H}), 1.88,(\mathrm{~s}, 3 \mathrm{H}), 1.80-1.73(\mathrm{~m}, 1 \mathrm{H}), 1.77$, (s, 3H), 1.69, (app. q, $J=7.1 \mathrm{~Hz}), 1.62-$ 1.52, (m, 1H), 1.44, (d, $J=5.6 \mathrm{~Hz}, 1 \mathrm{H}), 1.30-1.18(\mathrm{~m}, 8 \mathrm{H}), 1.28,(\mathrm{~s}, 3 \mathrm{H}), 1.09,(\mathrm{~d}, J=6.4 \mathrm{~Hz}$, 1H), 1.07, (m, 1H), 1.01, (d, $J=7.1, \mathrm{~Hz}, 1 \mathrm{H}), 0.89,(\mathrm{~d}, J=6.6 \mathrm{~Hz}, 1 \mathrm{H}), 0.86,(\mathrm{~d}, J=6.8 \mathrm{~Hz}$, $1 \mathrm{H}), 0.78(\mathrm{~d}, J=6.8 \mathrm{~Hz}, 1 \mathrm{H}) ;{ }^{13} \mathrm{C} \mathrm{NMR}\left(4: 1 \mathrm{CDCl}_{3} / \mathrm{C}_{6} \mathrm{H}_{6}, 125 \mathrm{MHz}\right) \delta 169.5,153.6,143.2$, 142.5, 134.6, 132.7, 127.4, 125.3, 114.9, 99.3, 86.4, 82.2, 80.0, 77.8, 75.8, 74.8, 70.4, 70.3, 69.2, 55.6, 47.1, 45.9, 43.4, 41.7, 37.2, 34.7, 32.0, 30.1, 25.7, 24.9, 22.7, 20.1, 19.3, 14.1, 12.9, 11.6, 9.7, 7.1; IR (thin film, benzene) 3419, 2929, 1682, 1455, 1260, 1150, 1087, 1037, 968, 899, 847, 808, $678 \mathrm{~cm}^{-1}$; HRMS (FAB) for $\mathrm{C}_{38} \mathrm{H}_{62} \mathrm{O}_{10} \mathrm{Na}[\mathrm{M}+\mathrm{Na}]^{+}$calcd. 701.4241, found $701.4244 \mathrm{~m} / \mathrm{z}$. 
Table 1: ${ }^{1} \mathrm{H}-\mathrm{NMR}$ and ${ }^{13} \mathrm{C}-\mathrm{NMR}$ Data of formamicin and formamicin aglycon.

\begin{tabular}{|c|c|c|c|c|c|c|}
\hline Position & Formamicin & $\begin{array}{l}{ }^{13} \mathrm{C}-\mathrm{NMR} \\
\text { Formamicin } \\
\text { aglycon }\end{array}$ & Difference & Formamicin & $\begin{array}{c}{ }^{1} \mathrm{H}-\mathrm{NMR} \\
\text { Formamicin } \\
\text { Aglycon }\end{array}$ & Difference \\
\hline 1 & 169.6 & 169.5 & 0.1 & & & 0.00 \\
\hline 2 & 115.0 & 114.9 & 0.1 & 5.69 & 5.65 & 0.04 \\
\hline 3 & 153.8 & 153.6 & 0.2 & 7.27 & 7.22 & 0.05 \\
\hline 4 & 134.6 & 134.6 & 0.0 & & & 0.00 \\
\hline 5 & 142.6 & 142.5 & 0.1 & 5.71 & 5.68 & 0.03 \\
\hline 6 & 80.0 & 80.0 & 0.0 & & & 0.00 \\
\hline \multirow[t]{2}{*}{7} & 74.8 & 74.8 & 0.0 & 3.56 & 3.51 & 0.05 \\
\hline & & & & 1.66 & 1.58 & 0.08 \\
\hline 8 & 47.2 & 47.1 & 0.1 & 2.65 & 2.60 & 0.05 \\
\hline \multirow[t]{2}{*}{9} & 34.8 & 34.7 & 0.1 & 1.83 & 1.78 & 0.05 \\
\hline & & & & 1.97 & 1.92 & 0.05 \\
\hline 10 & 143.4 & 143.2 & 0.2 & & & 0.00 \\
\hline 11 & 125.3 & 125.3 & 0.0 & 5.76 & 5.71 & 0.05 \\
\hline 12 & 132.9 & 132.7 & 0.2 & 6.53 & 6.48 & 0.05 \\
\hline 13 & 127.8 & 127.4 & 0.4 & 5.20 & 5.15 & 0.05 \\
\hline 14 & 82.3 & 82.2 & 0.1 & 3.91 & 3.86 & 0.05 \\
\hline 15 & 75.8 & 75.8 & 0.0 & 4.96 & 4.91 & 0.05 \\
\hline 16 & 37.3 & 37.2 & 0.1 & 2.19 & 2.14 & 0.05 \\
\hline \multirow[t]{2}{*}{17} & 70.5 & 70.4 & 0.1 & 4.20 & 4.14 & 0.06 \\
\hline & & & 0.0 & 4.87 & 4.78 & 0.09 \\
\hline 18 & 41.9 & 41.7 & 0.2 & 1.76 & 1.69 & 0.07 \\
\hline 19 & 99.4 & 99.3 & 0.1 & 5.71 & 5.64 & 0.07 \\
\hline \multirow[t]{2}{*}{20} & 40.2 & 45.9 & -5.7 & 1.17 & 1.07 & 0.10 \\
\hline & & & & 2.34 & 2.24 & 0.10 \\
\hline \multirow[t]{2}{*}{21} & 76.2 & 69.2 & 7.0 & 3.81 & 3.63 & 0.18 \\
\hline & & & 0.0 & & 1.44 & $21(\mathrm{OH})$ \\
\hline $22^{\mathrm{a}}$ & 43.7 & 43.4 & 0.3 & $1.20-1.35$ & $1.18-1.30$ & 0.04 \\
\hline 23 & 69.8 & 70.3 & -0.5 & 3.78 & 3.70 & 0.08 \\
\hline 24 & 19.5 & 19.3 & 0.2 & 1.15 & 1.09 & 0.06 \\
\hline 25 & 78.0 & 77.8 & 0.2 & 3.61 & 3.56 & 0.05 \\
\hline $26^{\mathrm{a}}$ & 30.2 & 30.1 & 0.1 & $1.20-1.35$ & $1.18-1.30$ & 0.04 \\
\hline $27^{\mathrm{a}}$ & 25.8 & 25.7 & 0.1 & $1.20-1.35$ & $1.18-1.30$ & 0.04 \\
\hline $28^{\mathrm{a}}$ & 32.0 & 32.0 & 0.0 & $1.20-1.35$ & $1.18-1.30$ & 0.04 \\
\hline $29^{a}$ & 22.8 & 22.7 & 0.1 & $1.20-1.35$ & $1.18-1.30$ & 0.04 \\
\hline 30 & 14.2 & 14.1 & 0.1 & 0.91 & 0.86 & 0.05 \\
\hline 31 & 11.7 & 11.6 & 0.1 & 1.83 & 1.77 & 0.06 \\
\hline 32 & 24.9 & 24.9 & 0.0 & 1.33 & 1.28 & 0.05 \\
\hline 33 & 86.5 & 86.4 & 0.1 & 4.63 & 4.58 & 0.05 \\
\hline 34 & 20.2 & 20.1 & 0.1 & 1.93 & 1.88 & 0.05 \\
\hline 35 & 55.7 & 55.6 & 0.1 & 3.23 & 3.18 & 0.05 \\
\hline 36 & 9.7 & 9.7 & 0.0 & 0.83 & 0.78 & 0.05 \\
\hline 37 & 7.3 & 7.1 & 0.2 & 1.08 & 1.01 & 0.07 \\
\hline 38 & 13.3 & 12.9 & 0.4 & 0.99 & 0.89 & 0.10 \\
\hline
\end{tabular}

${ }^{\mathrm{a}}$ The proton resonances overlapped and could not be resolved. 


\section{Glycosidation Studies.}

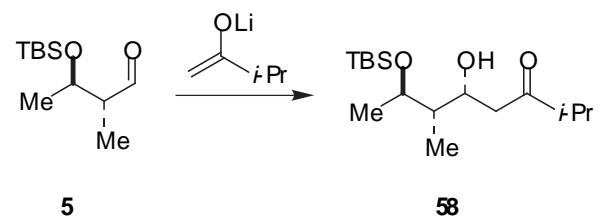

(5S, 6S, 7R)-6-Methyl-7-[(tert-butyldimethyl)silyloxy]-octan-5-ol-3-one (58). To a solution of LiHMDS (1M in THF, $7 \mathrm{~mL}, 7 \mathrm{mmol})$ in THF $(8 \mathrm{~mL})$ at $-78^{\circ} \mathrm{C}$ was slowly added neat isopropyl methyl ketone $(0.73 \mathrm{~mL}, 6.80 \mathrm{mmol})$. The mixture was stirred at $-75^{\circ} \mathrm{C}$ for 40 min, then a solution of aldehyde $5(0.5 \mathrm{~g}, 2.29 \mathrm{mmol})$ in THF $(2 \mathrm{~mL})$ was added dropwise over $15 \mathrm{~min}$ The reaction mixture was stirred for $1.75 \mathrm{~h}$ and quenched by inverse addition into a biphasic mixture of $\mathrm{Et}_{2} \mathrm{O}$ and a saturated aqueous solution of $\mathrm{NH}_{4} \mathrm{Cl}$. The aqueous layer was extracted with $\mathrm{CH}_{2} \mathrm{Cl}_{2}$, dried over $\mathrm{MgSO}_{4}$, filtered and concentrated under reduced pressure. The ratio of diastereomeric products was determined by ${ }^{1} \mathrm{H}$ NMR (500 MHz) to be 45/55 (Felkin : anti-Felkin). The crude yellow oil was filtrated on silica gel (hexanes - ethyl acetate =90:10). HPLC purification (hexanes/ethyl acetate $=92 / 8)$ gave $175 \mathrm{mg}(26 \%)$ of the Felkin diastereomer 58 as a colorless oil: $[\alpha]_{\mathrm{D}}{ }^{25}=-5.0\left(c 1.3, \mathrm{CHCl}_{3}\right) ;{ }^{1} \mathrm{H} \mathrm{NMR}\left(500 \mathrm{MHz}, \mathrm{CDCl}_{3}\right) \delta 4.53(\mathrm{~m}, 1 \mathrm{H})$, $3.86(\mathrm{dq}, J=6.3$ and $2.9 \mathrm{~Hz}, 1 \mathrm{H}), 3.45(\mathrm{~s}, 1 \mathrm{H}), 2.68(\mathrm{dd}, J=16.6$ and $8.8 \mathrm{~Hz}, 1 \mathrm{H}), 2.57$ (septet, $J$ $=6.8 \mathrm{~Hz}, 1 \mathrm{H}), 2.38(\mathrm{dd}, J=16.6$ and $4.9 \mathrm{~Hz}, 1 \mathrm{H}), 1.37(\mathrm{~m}, 1 \mathrm{H}), 1.22(\mathrm{~d}, J=6.3 \mathrm{~Hz}, 3 \mathrm{H}), 1.05$ $(\mathrm{d}, J=7.1 \mathrm{~Hz}, 3 \mathrm{H}), 1.04(\mathrm{~d}, J=6.8 \mathrm{~Hz}, 3 \mathrm{H}), 0.91(\mathrm{~d}, J=7.1 \mathrm{~Hz}, 3 \mathrm{H}), 0.83(\mathrm{~s}, 9 \mathrm{H}), 0.03(\mathrm{~s}, 6 \mathrm{H})$; ${ }^{13} \mathrm{C}$ NMR (125 MHz, CDCl3) d 214.0 73.4, 66.3, 45.0, 42.6, 41.3, 25.7, 21.8, 18.0, 17.8, -4.5, -5.2; IR (thin film) 3508, 2960m, 1711, 1464, 1383, 1112, 1079, 1006, 838, $776 \mathrm{~cm}^{-1}$; HRMS (ES) calcd for $\mathrm{C}_{16} \mathrm{H}_{34} \mathrm{O}_{3} \mathrm{NaSi}[\mathrm{M}+\mathrm{Na}]^{+}: 325.2175 \mathrm{~m} / \mathrm{z}$, observed $325.2173 \mathrm{~m} / \mathrm{z}$.

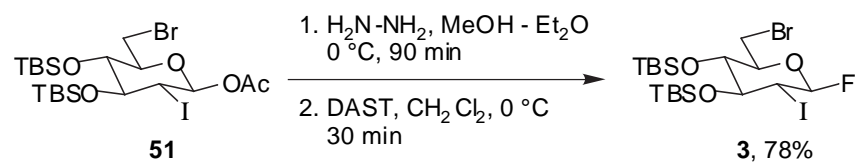

\section{6-Bromo-3,4-bis- $O$-(tert-butyldimethyl)silyl-2,6-deoxy-2-iodo- $\beta$-D-glucopyranosyl}

Fluoride (3). To a solution of 6-bromo-3,4-bis- $O$-(tert-butyldimethyl)silyl-2,6-deoxy-2-iodo- $\beta$ D-glucopyranosyl acetate $\mathbf{5 1}^{11}(885 \mathrm{mg}, 1.42 \mathrm{mmol})$ in $\mathrm{MeOH} / \mathrm{Et}_{2} \mathrm{O}(2 / 1,15 \mathrm{~mL})$ at $0{ }^{\circ} \mathrm{C}$ was 
added hydrazine $\left(11 \mathrm{M}\right.$ in $\left.\mathrm{H}_{2} \mathrm{O}, 220 \mu \mathrm{L}, 2.4 \mathrm{mmol}\right)$. After $1.5 \mathrm{~h}$ at $0{ }^{\circ} \mathrm{C}$, the reaction mixture was quenched by the addition of $\mathrm{H}_{2} \mathrm{O}(5 \mathrm{~mL})$ and extracted with $\mathrm{Et}_{2} \mathrm{O}$. The combined organic layers were washed with saturated $\mathrm{NaCl}$ solution, dried over $\mathrm{MgSO}_{4}$, filtered and concentrated under reduced pressure. The crude colorless oil was dissolved in $\mathrm{CH}_{2} \mathrm{Cl}_{2}$, and DAST (260 $\mu \mathrm{L}, 2.13$ mmol) was added dropwise at $0{ }^{\circ} \mathrm{C}$. After $30 \mathrm{~min}$ at $0{ }^{\circ} \mathrm{C}$, the reaction was poured into a saturated aqueous solution of $\mathrm{NaHCO}_{3}(3 \mathrm{~mL})$. The aqueous layer was extracted with $\mathrm{CH}_{2} \mathrm{Cl}_{2}$, washed with saturated $\mathrm{NaCl}$ solution, dried over $\mathrm{MgSO}_{4}$, filtered and concentrated under reduced pressure. The crude oil was purified by flash chromatography on silica gel (hexanes - ethyl acetate $=100$ : 1) to give $710 \mathrm{mg}$ of $\mathbf{3}$ (86\% from 51) as a colorless oil. Further purification by HPLC (hexanes ethyl acetate $=97: 3)$ gave $646 \mathrm{mg}$ of $\mathbf{3}(78 \%$ from 51) as a colorless oil (When high quality DAST was used in the reaction, HPLC purification was not necessary): $[\alpha]_{\mathrm{D}}{ }^{25}=+20.3(c 1.1$, $\left.\mathrm{CHCl}_{3}\right) ;{ }^{1} \mathrm{H} \mathrm{NMR}\left(500 \mathrm{MHz}, \mathrm{CDCl}_{3}\right) \delta 6.02\left(\mathrm{dd}, J=1.8 \mathrm{~Hz},{ }^{1} J_{H-F}=53.1 \mathrm{~Hz}, 1 \mathrm{H}\right), 4.30(\mathrm{bs}, 1 \mathrm{H})$, $4.19(\mathrm{~d}, J=3.3 \mathrm{~Hz}, 1 \mathrm{H}), 4.16(\mathrm{dd}, J=10.6$ and $6.2 \mathrm{~Hz}, 1 \mathrm{H}), 4.03-3.97(2 \mathrm{H}), 3.58(\mathrm{dd}, J=9.7$ and $4.9 \mathrm{~Hz}, 1 \mathrm{H}), 0.96(\mathrm{~s}, 9 \mathrm{H}), 0.91(\mathrm{~s}, 9 \mathrm{H}), 0.14(\mathrm{~s}, 2 \times 3 \mathrm{H}), 0.13(2 \times 3 \mathrm{H}) ;{ }^{13} \mathrm{C} \mathrm{NMR}(125 \mathrm{MHz}$, $\left.\mathrm{CDCl}_{3}\right) 108.8\left({ }^{1} J_{C-F}=222.8 \mathrm{~Hz}\right), 78.3,74.0,67.9,32.5,25.9,25.6,18.9,18.6,17.9\left({ }^{2} J_{C-F}=29\right.$ $\mathrm{Hz}),-4.5,-4.6,-4.8,-5.1$; IR (thin film) 2930, 1472, 1259, 1170, 1109, 938, 871, 835, $777 \mathrm{~cm}^{-1}$; HRMS (ES) calcd for $\mathrm{C}_{18} \mathrm{H}_{37} \mathrm{BrIFO}_{3} \mathrm{NaSi}_{2}[\mathrm{M}+\mathrm{Na}]^{+}: 605.0391 \mathrm{~m} / \mathrm{z}$, observed: $605.0397 \mathrm{~m} / \mathrm{z}$.
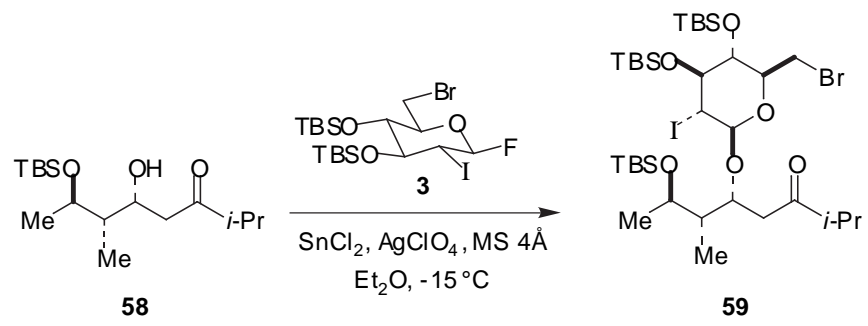

(5S，6S，7R)-5-O-[2-Deoxy-2-iodo-3,4-bis- $O$-(tert-butyldimethyl)silyl-6-bromo- $\beta$-Dglucopyranosyl)]-6-methyl-7-[(tert-butyldimethyl)silyloxy]-octan-3-one (59).

Representative Glycosidation Procedure: A solution of the acceptor 58 (20 mg, 0.066 $\mathrm{mmol})$ in $\mathrm{Et}_{2} \mathrm{O}(0.8 \mathrm{~mL})$ and flame-dried powdered $4 \AA$ molecular sieves was stirred at $23{ }^{\circ} \mathrm{C}$ for $45 \mathrm{~min}$ The suspension was then cooled to $-20{ }^{\circ} \mathrm{C}, \mathrm{SnCl}_{2}(124 \mathrm{mg}, 0.65 \mathrm{mmol})$ and $\mathrm{AgClO}_{4}(136$ $\mathrm{mg}, 0.65 \mathrm{mmol}$ ) were added successively followed by a slow addition of a solution of the donor $3(115 \mathrm{mg}, 0.2 \mathrm{mmol})$ in $\mathrm{Et}_{2} \mathrm{O}(0.5 \mathrm{~mL})$. The mixture was stirred for $1.5 \mathrm{~h}$ at $-20{ }^{\circ} \mathrm{C}$, then the 
bright yellow suspension was filtered through cotton and washed with $\mathrm{pH} 7$ buffer. The aqueous layer was extracted with $\mathrm{Et}_{2} \mathrm{O}$, washed with saturated $\mathrm{NaCl}$ solution, dried over $\mathrm{MgSO}_{4}$, filtered and concentrated under reduced pressure. The crude oil was purified by two successive preparative TLC runs (hexanes - ethyl acetate $=95: 5)$ to give $37 \mathrm{mg}(65 \%)$ of $\mathbf{5 9}$ as a colorless oil: $[\alpha]_{\mathrm{D}}{ }^{26}=+4.5\left(c 1.1, \mathrm{CHCl}_{3}\right) ;{ }^{1} \mathrm{H} \mathrm{NMR}\left(500 \mathrm{MHz}, \mathrm{CDCl}_{3}\right) \delta 5.19(\mathrm{~d}, J=8.3 \mathrm{~Hz}, 1 \mathrm{H}), 4.43$ $(\mathrm{dd}, J=5.9$ and $3.2 \mathrm{~Hz}, 1 \mathrm{H}), 4.40(\mathrm{~m}, 1 \mathrm{H}), 4.06(\mathrm{dt}, J=5.6$ and $2.9 \mathrm{~Hz}, 1 \mathrm{H}), 3.97(\mathrm{~d}, J=4.2 \mathrm{~Hz}$, $1 \mathrm{H}), 3.88(\mathrm{p}, J=6.1 \mathrm{~Hz}, 1 \mathrm{H}), 3.71(\mathrm{dd}, J=8.5 \mathrm{~Hz}, 1 \mathrm{H}), 3.65(\mathrm{dd}, J=10.0$ and $9.4 \mathrm{~Hz}, 1 \mathrm{H}), 3.46$ $(\mathrm{dd}, J=10.0$ and $5.4 \mathrm{~Hz}, 1 \mathrm{H}), 2.92(\mathrm{dd}, J=17.0$ and $6.2 \mathrm{~Hz}, 1 \mathrm{H}), 2.67-2.60(2 \mathrm{H}), 1.6(\mathrm{~m}, 1 \mathrm{H})$, 1.14-1.11 (9H including $1.13(\mathrm{~d}, J=7.1 \mathrm{~Hz}, 3 \mathrm{H})$ and $1.12(\mathrm{~d}, J=6.8 \mathrm{~Hz}, 3 \mathrm{H})), 0.96(\mathrm{~s}, 9 \mathrm{H}), 0.92$ (s, 9H), 0.90 (s, 9H), 0.87 (d, J = 7.1 Hz, 3H), 0.17 (s, 3H), 0.16 (s, 2x3H), 0.13 (s, 3H), 0.08 (s, 3H), 0.07 (s, 3H); ${ }^{13} \mathrm{C}$ NMR (125 MHz, $\left.\mathrm{CDCl}_{3}\right)$ 212.2, 99.2, 81.0, 80.7, 74.0, 71.9, 70.0, 45.3, 43.8, 41.2 , 32.5, 32.0, 25.9 (2C), 25.8, 20.7, 18.3, 18.1, 18.0 (2C), 17.9, 9.5, -4.1, -4.2 (2C), -4.3, -4.6 (2C); IR (thin film) 2930, 1716, 1472, 1362, 1257, 1093, 1037, 1006, $868 \mathrm{~cm}^{-1}$; HRMS (ES) calcd for $\mathrm{C}_{34} \mathrm{H}_{70} \mathrm{BrIO}_{6} \mathrm{NaSi}_{3}[\mathrm{M}+\mathrm{Na}]^{+}: 887.2606 \mathrm{~m} / \mathrm{z}$, observed: $887.2616 \mathrm{~m} / \mathrm{z}$.

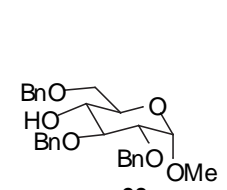

60

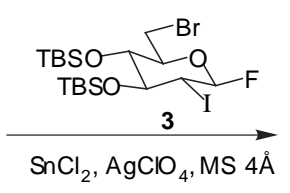

$\mathrm{Et}_{2} \mathrm{O},-15^{\circ} \mathrm{C}$ $88 \%$

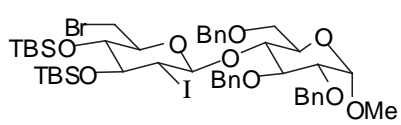

61

\section{Meth y $\quad 4$ - $O$-[2-Deoxy-2-iodo-3,4-bis- $O$-(tert-butyldimethyl)silyl-6-bromo- $\beta$-D-} glucopyranosyl)]-2,3,6-tri- $\boldsymbol{O}$-benzyl- $\boldsymbol{\alpha}$-D-glucopyranoside (61). Following the representative procedure described for the preparation of 59, the acceptor $\mathbf{6 0}^{12}(20 \mathrm{mg}, 0.04 \mathrm{mmol})$ in $\mathrm{Et}_{2} \mathrm{O}(0.5$ $\mathrm{mL})$ was treated with $\mathrm{SnCl}_{2}(73 \mathrm{mg}, 0.38 \mathrm{mmol})$ and $\mathrm{AgClO}_{4}(80 \mathrm{mg}, 0.38 \mathrm{mmol})$ followed by a slow addition of a solution of the donor $3(75 \mathrm{mg}, 0.13 \mathrm{mmol})$ in $\mathrm{Et}_{2} \mathrm{O}(0.5 \mathrm{~mL})$. After $20 \mathrm{~min}$ at $-15^{\circ} \mathrm{C}$, the reaction was worked up and the crude yellow oil was purified by preparative TLC (hexanes - ethyl acetate $=85: 15)$ to give $39 \mathrm{mg}(89 \%)$ of $61 .^{13}$ The $\beta / \alpha$ ratio was $>98: 2$ according to the ${ }^{1} \mathrm{H}$ NMR analysis (500 MHz). 


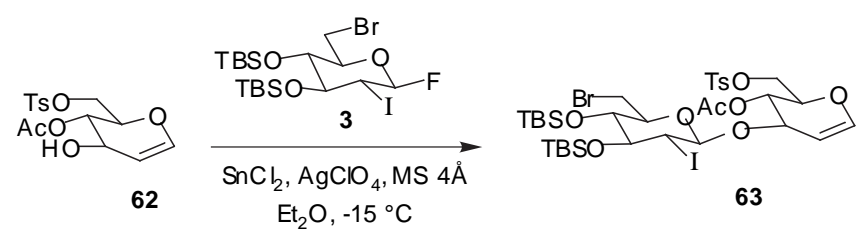

3- $O$-[2-Deoxy-2-iodo-3,4-bis- $O$-(tert-butyldimethyl)silyl-6-bromo- $\beta$-D-glucopyranosyl)]-2deoxy-4-O-acetyl-6- $O$-p-toluenesulfonyl-D-arabino-hex-1-enitol (63). Following the representative procedure described for the preparation of 59, the acceptor $\mathbf{6 2}^{14}(23.5 \mathrm{mg}, 0.07$ $\mathrm{mmol})$ in $\mathrm{Et}_{2} \mathrm{O}(1.0 \mathrm{~mL})$ was treated with $\mathrm{SnCl}_{2}(117 \mathrm{mg}, 0.62 \mathrm{mmol})$ and $\mathrm{AgClO}_{4}(128 \mathrm{mg}, 0.62$ mmol) followed by a slow addition of a solution of the donor 3 (120 mg, $0.21 \mathrm{mmol}^{2}$ in $\mathrm{Et}_{2} \mathrm{O}$ $(0.5 \mathrm{~mL})$. After $10 \mathrm{~min}$ at $-10^{\circ} \mathrm{C}$, the reaction was worked up and the $\beta / \alpha$ ratio was $>98: 2$ according to the ${ }^{1} \mathrm{H}$ NMR analysis $(500 \mathrm{MHz})$. The crude yellow oil was purified by preparative TLC (hexanes - ethyl acetate $=70: 30)$ to give $56 \mathrm{mg}(89 \%)$ of 63 as a colorless oil: $[\alpha]_{\mathrm{D}}{ }^{24}=-3.3$ $\left(c 0.30, \mathrm{CHCl}_{3}\right) ;{ }^{1} \mathrm{H} \mathrm{NMR}\left(500 \mathrm{MHz}, \mathrm{CDCl}_{3}\right) \delta 7.80(\mathrm{~d}, J=8.3 \mathrm{~Hz}, 2 \mathrm{H}), 7.33(\mathrm{t}, J=8.3 \mathrm{~Hz}, 2)$, $6.33(\mathrm{~d}, J=6.3 \mathrm{~Hz}, 1 \mathrm{H}), 5.30(\mathrm{~d}, J=8.5 \mathrm{~Hz}, 1 \mathrm{H}), 5.17(\mathrm{~m}, 1 \mathrm{H}), 4.93(\mathrm{~m}, 1 \mathrm{H}), 4.47-4.39(3 \mathrm{H})$, $4.18(\mathrm{~d}, J=10.5 \mathrm{~Hz}, 1 \mathrm{H}), 4.08(\mathrm{t}, J=7.3 \mathrm{~Hz}, 1 \mathrm{H}), 4.02(\mathrm{~m}, 1 \mathrm{H}), 3.95(\mathrm{~d}, J=3.4 \mathrm{~Hz}, 1 \mathrm{H}), 3.71$ $(\mathrm{dd}, J=8.3$ and $2.0 \mathrm{~Hz}, 1 \mathrm{H}), 3.63(\mathrm{dd}, J=8.8$ and $10.0 \mathrm{~Hz}, 1 \mathrm{H}), 3.40(\mathrm{dd}, J=10.0$ and $6.0 \mathrm{~Hz}$, 1H), 2.45 (s, 3H), 2.07 (s, 3H), 0.96 (s, 9H), 0.93 (s, 9H), 0.17 (s, 3H), $0.16(\mathrm{~s}, 3 \mathrm{H}), 0.15$ (s, 3H), $0.14(\mathrm{~s}, 3 \mathrm{H}) ;{ }^{13} \mathrm{C}$ NMR $\left(125 \mathrm{MHz}, \mathrm{CDCl}_{3}\right)$ 169.4, 144.8, 144.4, 132.9, 129.8, 128.1, 99.7, 97.4, $81.3,80.4,73.5,71.6,68.7,67.9,67.5,32.2,30.4,25.8(2 \mathrm{C}), 21.6,20.9,17.9$ (2C), -4.1, -4.3, 4.4, -4.7; IR (thin film) 2930, 1747, 1651, 1369, 1231, 1190, 1178, 1098, 968, 834, 778, $668 \mathrm{~cm}^{-}$ ${ }^{1}$; HRMS (ES) calcd for $\mathrm{C}_{33} \mathrm{H}_{54} \mathrm{BrIO}_{10} \mathrm{NaSSi}_{2}[\mathrm{M}+\mathrm{Na}]^{+}$: $927.1102 \mathrm{~m} / \mathrm{z}$, observed: $927.1098 \mathrm{~m} / \mathrm{z}$.

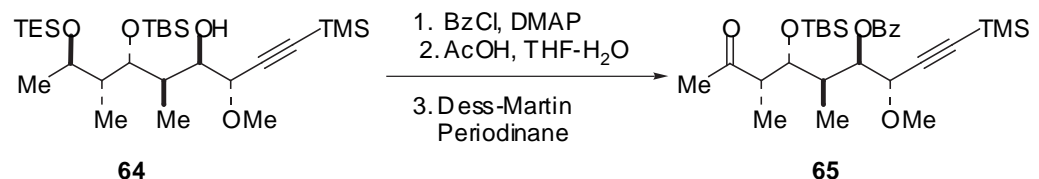

(3S, 4R, 5R, 6R, 7S) 3,5-Dimethyl-4-[(tert-butyldimethyl)silyloxy]-6-[(benzoyl)oxy]7-methoxy-non-8-yn-2-one (65). To a solution of $64^{8,9}$ ( $\left.112 \mathrm{mg}, 0.211 \mathrm{mmol}\right)$ in $\operatorname{dry} \mathrm{CH}_{2} \mathrm{Cl}_{2}(2$ $\mathrm{mL})$ was added sequentially $\mathrm{Et}_{3} \mathrm{~N}(140 \mu \mathrm{L}, 1.00 \mathrm{mmol})$, benzoyl chloride $(\mathrm{BzCl}, 86 \mathrm{~mL}, 0.74$ mmol), and DMAP (91 $\mathrm{mg}, 0.75 \mathrm{mmol})$. After $3 \mathrm{~h}$, the reaction was diluted with ether and washed with water (x1), saturated $\mathrm{NaHCO}_{3}(\mathrm{x} 2)$, saturated $\mathrm{NaCl}$ solution, dried over $\mathrm{Na}_{2} \mathrm{SO}_{4}$, 
filtered, and concentrated to give the benzoate as a yellow oil. This material was used directly in the next reaction.

The crude benzoate from the previous reaction was dissolved in THF $(0.9 \mathrm{~mL})$ and $\mathrm{AcOH}(0.9 \mathrm{~mL})$ was added followed by water $(0.15 \mathrm{~mL})$. After $16 \mathrm{~h}$, the reaction was diluted with ether and washed with water (x1), saturated $\mathrm{NaHCO}_{3}(\mathrm{x} 3)$, saturated $\mathrm{NaCl}$ solution, dried over $\mathrm{Na}_{2} \mathrm{SO}_{4}$, filtered, and concentrated to give $137 \mathrm{mg}$ of a yellow oil which was used directly in the next reaction.

The crude alcohol from the previous reaction was dissolved in $0.5 \mathrm{~mL}$ of dry $\mathrm{CH}_{2} \mathrm{Cl}_{2}$ and treated with pyridine $(38 \mu \mathrm{L}, 0.47 \mathrm{mmol})$ and Dess-Martin periodinane ${ }^{15}$ (144 $\left.\mathrm{mg}, 0.340 \mathrm{mmol}\right)$. To this solution was then added "wet" $\mathrm{CH}_{2} \mathrm{Cl}_{2}(1.5 \mathrm{~mL}$, prepared from vigorously mixing $10 \mathrm{~mL}$ $\mathrm{CH}_{2} \mathrm{Cl}_{2}$ and $10 \mu \mathrm{L}$ of water $)^{16}$ dropwise. After $40 \mathrm{~min}$, an additional portion of Dess-Martin periodinane $(32 \mathrm{mg}$ ) was added and the reaction was stirred for an additional $10 \mathrm{~min}$ The reaction was then diluted with ether, washed with $10 \% \mathrm{Na}_{2} \mathrm{~S}_{2} \mathrm{O}_{3}$ solution (x2), saturated $\mathrm{NaCl}$ solution, dried over $\mathrm{Na}_{2} \mathrm{SO}_{4}$, filtered, and concentrated. The residue was purified by flash chromatography $\left(90: 10\right.$ hexanes/Et $\left.{ }_{2} \mathrm{O}\right)$ to give 65 as a clear oil $(105 \mathrm{mg}, 96 \%$ from 64$):[\alpha]_{\mathrm{D}}^{25}=$ +5.3 $\left(c=0.4, \mathrm{CHCl}_{3}\right) ;{ }^{1} \mathrm{H} \mathrm{NMR}\left(500 \mathrm{MHz}, \mathrm{CDCl}_{3}\right) \delta 8.07(\mathrm{~m}, 2 \mathrm{H}), 7.55(\mathrm{~m}, 1 \mathrm{H}), 7.43(\mathrm{~m}, 2 \mathrm{H})$, $5.31(\mathrm{dd}, J=5.5,4.5 \mathrm{~Hz}, 1 \mathrm{H}), 4.28(\mathrm{~d}, J=5.0 \mathrm{~Hz}, 1 \mathrm{H}), 3.37(\mathrm{~s}, 3 \mathrm{H}), 2.82(\mathrm{~m}, 1 \mathrm{H}), 2.23(\mathrm{~m}, 1 \mathrm{H})$, $2.22(\mathrm{~s}, 3 \mathrm{H}), 1.15(\mathrm{~d}, J=7.5 \mathrm{~Hz}, 3 \mathrm{H}), 1.09$ (d, J = $7.5 \mathrm{~Hz}, 3 \mathrm{H}), 0.85$ (s, 9H), .12 (s, 9H), 0.09 (s, 3H), 0.02 (s, 3H); ${ }^{13} \mathrm{C}$ NMR (125 MHz, $\mathrm{CDCl}_{3}$ ) 211.8, 166.0, 133.1, 130.7, 130.1, 128.5, 101.3, $93.1,74.1,73.7,73.3,57.3,50.3,40.01,29.8,26.2,18.5,13.2,12.1,-0.1,-3.9,-4.1$; IR (thin film) $1723 \mathrm{~cm}^{-1}$; HRMS (ES) calcd for $\mathrm{C}_{28} \mathrm{H}_{46} \mathrm{O}_{5} \mathrm{NaSi}_{2}[\mathrm{M}+\mathrm{Na}]^{+}: 541.2782 \mathrm{~m} / \mathrm{z}$, observed: $541.2781 \mathrm{~m} / \mathrm{z}$.

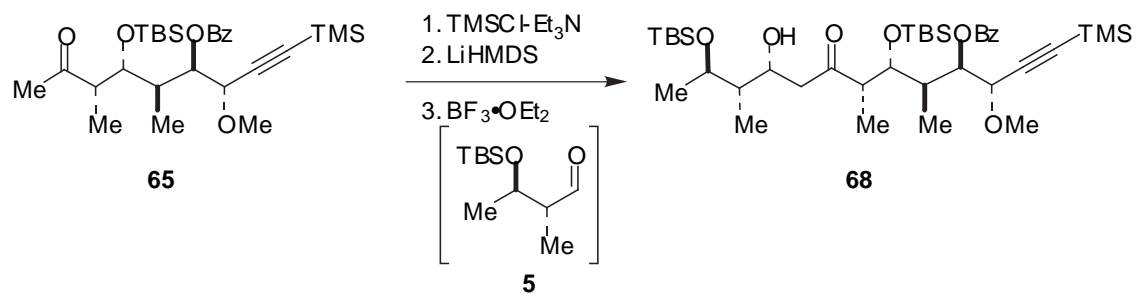

$(2 \mathrm{R}, 3 \mathrm{~S}, 4 \mathrm{R}, 7 \mathrm{~S}, \mathrm{RR}, 9 \mathrm{R}, 10 \mathrm{R}, 11 \mathrm{~S})-2,8-\mathrm{Di}$ -[(tert-butyldimethyl)silyloxy]-3,7,9trimethyl-10-[(benzoyl)oxy]-11-methoxy-13-trimethylsilyl-tridec-4-ol-12-yn-6 one (68). To a solution of $65(80 \mathrm{mg}, 0.15 \mathrm{mmol})$ in $\mathrm{THF}(1.5 \mathrm{~mL})$ at $-78{ }^{\circ} \mathrm{C}$ was added $0.2 \mathrm{~mL}$ of a $1: 1$ 
solution of $\mathrm{TMSCl}$ and $\mathrm{Et}_{3} \mathrm{~N}(0.4 \mathrm{~mL})$. LiHMDS (1 M solution in THF, $\left.0.50 \mathrm{~mL}, 0.50 \mathrm{mmol}\right)$ was added dropwise. The mixture was stirred for $1 \mathrm{~h}$ at $-78{ }^{\circ} \mathrm{C}$, then $\mathrm{pH} 7$ buffer $(5 \mathrm{~mL})$ and pentane $(5 \mathrm{~mL})$ were added and the solution was allowed to warm to $23{ }^{\circ} \mathrm{C}$. The aqueous layer was extracted with pentane, dried over $\mathrm{MgSO}_{4}$, filtered and concentrated under reduced pressure. The crude oil was used in the next step without any further purification.

To a solution of the crude enol ether and aldehyde $5(70 \mathrm{mg}, 0.32 \mathrm{mmol})$ in $\mathrm{CH}_{2} \mathrm{Cl}_{2}(0.8$ $\mathrm{mL})$ at $-78{ }^{\circ} \mathrm{C}$ was added $\mathrm{BF}_{3} \bullet \mathrm{OEt}_{2}(40 \mu \mathrm{L}, 0.504 \mathrm{mmol})$. After $1 \mathrm{~h}$ at $-78{ }^{\circ} \mathrm{C}$, the reaction mixture was quenched by $\mathrm{pH} 7$ buffer and diluted with ether. The layers were separated and the aqueous layer was extracted with ether. The organic phases were combined, dried over $\mathrm{Na}_{2} \mathrm{SO}_{4}$, filtered, and concentrated under reduced pressure. The diastereomeric ratio was determined by ${ }^{1} \mathrm{H}$ NMR analysis $(500 \mathrm{MHz})$ to be $>96 / 4$ in favor of the desired Felkin aldol product 67. The crude yellow oil was purified by flash chromatography (hexanes - ethyl acetate $=95: 5$ ) to give $75 \mathrm{mg}(66 \%)$ of 67 as a clear oil: $[\alpha]_{\mathrm{D}}{ }^{23}=+42.0^{\circ}\left(c 0.64, \mathrm{CHCl}_{3}\right) ;{ }^{1} \mathrm{H} \mathrm{NMR}\left(500 \mathrm{MHz}, \mathrm{CDCl}_{3}\right) \delta$ 8.05-8.03 (2H), $7.52(\mathrm{~m}, 1 \mathrm{H}), 7.42-7.38(2 \mathrm{H}), 5.24(\mathrm{dd}, J=5.7$ and $4.6 \mathrm{~Hz}, 1 \mathrm{H}), 4.57(\mathrm{~m}, 1 \mathrm{H})$, $4.23(\mathrm{~d}, J=4.6 \mathrm{~Hz}, 1 \mathrm{H}), 4.09(\mathrm{dd}, J=5.7$ and $4.6 \mathrm{~Hz}, 1 \mathrm{H}), 3.88(\mathrm{dq}, J=6.2$ and $3.7 \mathrm{~Hz}, 1 \mathrm{H})$, $3.42(\mathrm{~d}, J=1.1 \mathrm{~Hz}, 1 \mathrm{H}), 3.33(\mathrm{~s}, 3 \mathrm{H}), 2.86-2.76(2 \mathrm{H}), 2.48(\mathrm{dd}, J=17.2$ and $4.0 \mathrm{~Hz}, 1 \mathrm{H}), 2.20$ $(\mathrm{m}, 1 \mathrm{H}), 1.41(\mathrm{~m}, 1 \mathrm{H}), 1.24(\mathrm{~d}, J=6.2 \mathrm{~Hz}, 3 \mathrm{H}), 1.12(\mathrm{~d}, J=7.0 \mathrm{~Hz}, 3 \mathrm{H}), 1.05$ (d, J = 7.0 Hz, $3 \mathrm{H}), 0.94(\mathrm{~d}, J=7.0 \mathrm{~Hz}, 3 \mathrm{H}), 0.85(\mathrm{~s}, 9 \mathrm{H}), 0.81(\mathrm{~s}, 9 \mathrm{H}), 0.08(\mathrm{~s}, 9 \mathrm{H}), 0.05(\mathrm{~s}, 9 \mathrm{H}), 0.00$ (s, 3H); ${ }^{13} \mathrm{C}$ NMR (125 MHz, $\mathrm{CDCl}_{3}$ ) 212.7, 165.7, 132.8, 130.5, 129.9, 128.2, 101.1, 92.7, 73.8, 73.5, 73.3, 73.0, 66.1, 57.0, 50.0, 47.1, 42.8, 39.9, 26.0, 25.8, 21.9, 18.2, 17.9, 13.1, 11.6, 11.2, -4.0, 4.3, -4.4, -5.0; IR (thin film) 3501, 2956, 1728, 1463, 1378, 1252, 1108, 1027, 839, 776, $709 \mathrm{~cm}^{-}$

${ }^{1}$; HRMS (ES) calcd for $\mathrm{C}_{36} \mathrm{H}_{70} \mathrm{O}_{7} \mathrm{NaSi}_{2}[\mathrm{M}+\mathrm{Na}]^{+}: 757.4327 \mathrm{~m} / \mathrm{z}$, observed: $757.4330 \mathrm{~m} / \mathrm{z}$.
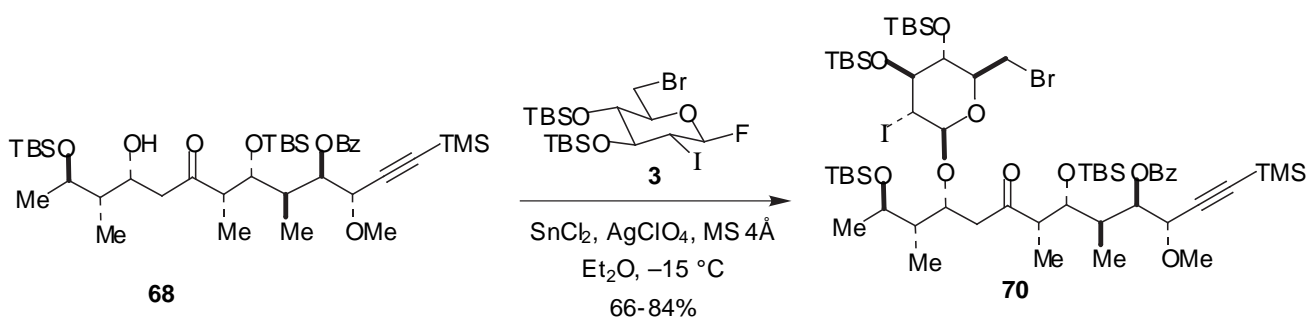

(2R，3S，4R，7S，8R，9R，10R，11S)-2,8-Bis-[(tert-butyldimethyl)silyloxy]-3,7,9trimethyl-4- $O$-[2-deoxy-2-iodo-3,4-bis- $O$-(tert-butyldimethyl)silyl-6-bromo- $\beta$-D- 
glucopyranosyl)]-10-[(benzoyl)oxy]-11-methoxy-13-trimethylsilyl-tridec-4-ol-12-yn-6-one

(70). Following the representative procedure described for the preparation of 59, the acceptor 68 $(12.8 \mathrm{mg}, 0.017 \mathrm{mmol})$ in $\mathrm{Et}_{2} \mathrm{O}(0.9 \mathrm{~mL})$ was treated with $\mathrm{SnCl}_{2}(29 \mathrm{mg}, 0.15 \mathrm{mmol})$ and $\mathrm{AgClO}_{4}(32.2 \mathrm{mg}, 0.15 \mathrm{mmol})$ followed by a slow addition of a solution of the $14(30.5 \mathrm{mg}, 0.05$ $\mathrm{mmol})$ in $\mathrm{Et}_{2} \mathrm{O}(0.5 \mathrm{~mL})$. The mixture was stirred for $30 \mathrm{~min}$ at $-15^{\circ} \mathrm{C}$, the reaction was worked up and ${ }^{1} \mathrm{H}$ NMR analysis of the crude product indicated that $8 \%$ of the starting aldol $\mathbf{6 8}$ were still present. The crude yellow oil was filtered through silica gel (hexanes - ethyl acetate $=100: 1$ to 95:5). HPLC purification (hexanes - ethyl acetate $=97: 3)$ gave $19 \mathrm{mg}(84 \%)$ of 70: $[\alpha]_{\mathrm{D}}{ }^{23}=$ $+24.4\left(c\right.$ 0.73, $\left.\mathrm{CHCl}_{3}\right) ;{ }^{1} \mathrm{H} \mathrm{NMR}\left(500 \mathrm{MHz}, \mathrm{CDCl}_{3}\right) \delta 8.06(\mathrm{~d}, J=7.1 \mathrm{~Hz}, 2 \mathrm{H}), 7.54(\mathrm{t}, J=7.6$ $\mathrm{Hz}, 1 \mathrm{H}), 7.42(\mathrm{t}, J=7.6 \mathrm{~Hz}, 2 \mathrm{H}), 5.32(\mathrm{t}, J=4.9 \mathrm{~Hz}, 1 \mathrm{H}), 5.15(\mathrm{~d}, J=8.3 \mathrm{~Hz}, 1 \mathrm{H}), 4.43(\mathrm{~m}, 1 \mathrm{H})$, $4.36(\mathrm{~m}, 1 \mathrm{H}), 4.25(\mathrm{~d}, J=5.1 \mathrm{~Hz}, 1 \mathrm{H}), 4.11(\mathrm{t}, J=5.1 \mathrm{~Hz}, 1 \mathrm{H}), 4.01(\mathrm{br} \mathrm{t}, J=7.1 \mathrm{~Hz}, 1 \mathrm{H}), 3.94-$ $3.89(2 \mathrm{H}), 3.66(\mathrm{dd}, J=7.1$ and $2.1 \mathrm{~Hz}, 1 \mathrm{H}), 3.62(\mathrm{dd}, J=10.0$ and $8.6 \mathrm{~Hz}, 1 \mathrm{H}), 3.44(\mathrm{dd}, J=$ 10.0 and $5.6 \mathrm{~Hz}, 1 \mathrm{H}), 3.36(\mathrm{~s}, 3 \mathrm{H}), 2.96(\mathrm{dd}, J=18.0$ and $6.7 \mathrm{~Hz}, 1 \mathrm{H}), 2.83(\mathrm{~m}, 1 \mathrm{H}), 2.67(\mathrm{dd}, J$ $=18.0$ and $4.6 \mathrm{~Hz}, 1 \mathrm{H}), 2.19(\mathrm{~m}, 1 \mathrm{H}), 1.67(\mathrm{~m}, 1 \mathrm{H}), 1.18(\mathrm{~d}, J=7.3 \mathrm{~Hz}, 3 \mathrm{H}), 1.08(\mathrm{~d}, J=6.3 \mathrm{~Hz}$, 6H), 0.95 (s, 9H), 0.90 (s, 9H), 0.87 (s, 9H), 0.86 (d, J = 7.1 Hz, 3H), 0.84 (s, 9H), 0.15 (s, 3H), 0.14 (s, 3H), 0.13 (s, 3H), 0.11 (s, 3H), 0.10 (s, 9H), 0.07 (s, 3H), 0.06 (s, 3H), 0.05 (s, 3H), 0.00 (s, 3H); ${ }^{13} \mathrm{C} \mathrm{NMR}\left(125 \mathrm{MHz}, \mathrm{CDCl}_{3}\right)$ 210.6, 165.6, 132.8, 130.6, 129.9, 128.2, 101.1, 99.6, 92.8, 80.8, 80.6, 73.6, 73.5 (2C), 73.0, 72.0, 69.9, 57.0, 50.0, 45.6, 45.4, 39.6, 32.7, 32.0, 26.1, 25.9 (2C), 25.8, 20.5, 18.3, 18.0 (2C), 17.9, 13.0, 11.9, 9.3, -0.3, -4.0 (2C), -4.1, -4.2 (2C), -4.3, -4.6, 4.7; IR (thin film) 2955, 1723, 1472, 1361, 1252, 1097, 1005, 835, 776, $708 \mathrm{~cm}^{-1}$; HRMS (ES) calcd for $\mathrm{C}_{57} \mathrm{H}_{106} \mathrm{BrIO}_{10} \mathrm{NaSi}_{5}[\mathrm{M}+\mathrm{Na}]^{+}: 1319.4758 \mathrm{~m} / \mathrm{z}$, observed: $1319.4774 \mathrm{~m} / \mathrm{z}$.

\section{E. Deprotection Studies.}

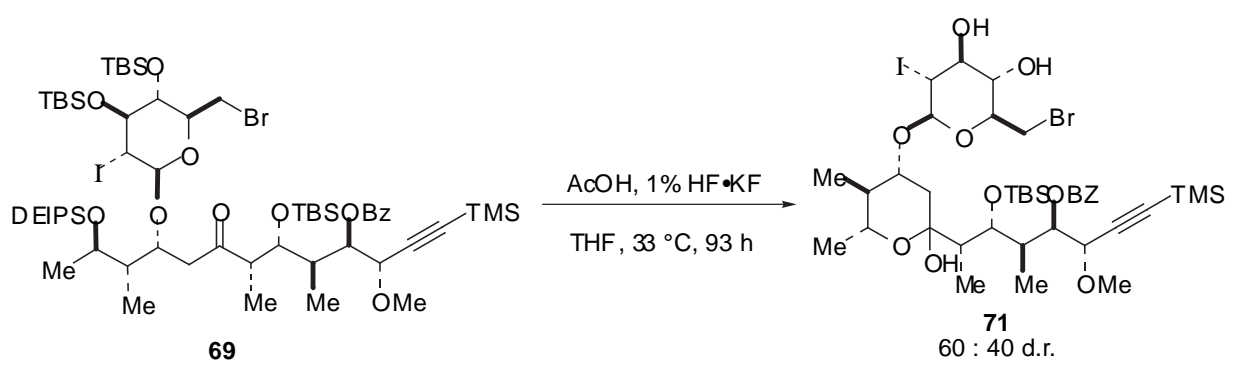


(3S,4R,5R,6R,7S)-4-(Benzoyl)oxy-6-(tert-butyldimethyl)silyloxy-7-[(2'S,4'R,5'S,6'S,)-

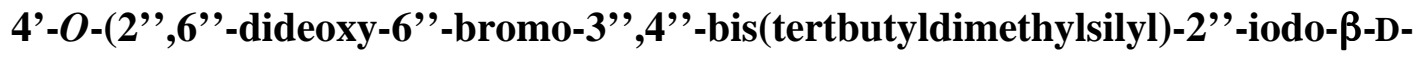
glucopyranosyl)-2-hydroxy-5,6-dimethyl-tetrahydropyranyl-2-yl]-3-methoxy-5-methyl-1trimethylsilyloct-1-yne (71). Glycoside $69(60 \mathrm{mg}, 0.045 \mathrm{mmol})$ was dissolved in THF $(0.4 \mathrm{~mL})$ in a plastic tube under nitrogen. To this solution was added $\mathrm{AcOH}(0.4 \mathrm{~mL})$ followed by $1 \%$ $\mathrm{HF} \bullet \mathrm{KF}_{\text {(aq.) }}(0.13 \mathrm{~mL})$. The resulting mixture was heated at $33{ }^{\circ} \mathrm{C}$ for $96 \mathrm{~h}$. The reaction was diluted with $\mathrm{CH}_{2} \mathrm{Cl}_{2}$ and washed with $\mathrm{pH} 7$ buffer. The aqueous washes were combined and extracted with $\mathrm{CH}_{2} \mathrm{Cl}_{2}$. The organic extracts were combined, washed with saturated $\mathrm{NaCl}$ solution, dried over $\mathrm{MgSO}_{4}$, filtered and concentrated. The residue was purified by preparative TLC (15\% EtOAc/hexanes) to give $15.3 \mathrm{mg}$ of recovered $\mathbf{6 9}$ and $39.9 \mathrm{mg}$ of 71 (75\% overall, quantitative based on recovered 69) as a mixture (60/40) of diastereomeric ketals. These diastereomers could be separated by HPLC. The major diastereomer was used in all subsequent reactions. The stereochemistry of the major diastereomer was assigned as $\mathbf{7 1}$ by analogy to $\mathbf{1}$. Data for the major diastereomer: $[\alpha]_{\mathrm{D}}{ }^{24}=+21.0\left(c 0.79, \mathrm{CHCl}_{3}\right) ;{ }^{1} \mathrm{H} \mathrm{NMR}\left(500 \mathrm{MHz}, \mathrm{CDCl}_{3}\right) \delta$ $8.11(\mathrm{~d}, J=7.5 \mathrm{~Hz}, 2 \mathrm{H}), 7.57(\mathrm{t}, J=7.0 \mathrm{~Hz}, 1 \mathrm{H}), 7.45(\mathrm{~d}, J=7.5 \mathrm{~Hz}, 2 \mathrm{H}), 5.25(\mathrm{dd}, J=3.0,9.0$ $\mathrm{Hz}, 1 \mathrm{H}), 5.21(\mathrm{~d}, J=8.5 \mathrm{~Hz}, 1 \mathrm{H}), 4.78(\mathrm{~d}, J=5.0 \mathrm{~Hz}, 1 \mathrm{H}), 4.46(\mathrm{~d}, J=3.0 \mathrm{~Hz}, 1 \mathrm{H}), 4.42(\mathrm{aq}, J=$ $2.0 \mathrm{~Hz}, 1 \mathrm{H}), 4.03$, (at, $J=7.5 \mathrm{~Hz}, 1 \mathrm{H}), 3.96(\mathrm{dd}, J=1.5,4.0 \mathrm{~Hz}, 1 \mathrm{H}), 3.77-3.64(\mathrm{~m}, 4 \mathrm{H}), 3.50(\mathrm{~d}$, $J=2.0 \mathrm{~Hz}, 1 \mathrm{H}), 3.46(\mathrm{dd}, J=5.5,10.0 \mathrm{~Hz}, 1 \mathrm{H}), 3.37(\mathrm{~s}, 3 \mathrm{H}), 2.47(\mathrm{~m}, 1 \mathrm{H}), 2.39(\mathrm{dd}, J=4.5$, $12.0 \mathrm{~Hz}, 1 \mathrm{H}), 1.77(\mathrm{dd}, J=7.0,14.0 \mathrm{~Hz}, 1 \mathrm{H}), 1.27(\mathrm{~s}, 3 \mathrm{H}), 1.23(\mathrm{~d}, J=6.5 \mathrm{~Hz}, 3 \mathrm{H}), 1.11(\mathrm{~d}, J=$ $7.0 \mathrm{~Hz}, 3 \mathrm{H}$ ), 1.06 (d, J = 7.5 Hz, 3H), 0.96 (s, 9H), 0.94 (s, 9H), 0.93 (s, 9H), 0.22 (s, 9H), 0.22 (s, 3H), 0.19 (s, 3H), 0.17 (s, 6H), 0.16 (s, 3H), 0.15 (s, 3H); $\left.{ }^{13} \mathrm{C} \mathrm{NMR} \mathrm{(125} \mathrm{MHz,} \mathrm{CDCl}_{3}\right) \delta$ 166.1, 132.9, 130.3, 130.0, 128.2, 100.7, 99.5, 98.5, 92.4, 80.8, 77.5, 76.9, 75.5, 72.0, 70.1, 68.8, 56.9, 43.3., 40.6, 38.5, 32.7, 32.1, 29.7, 25.9 (2C), 19.5, 18.0 (2C), 17.9, 13.2, 10.9, 9.7, -0.01, $-2.8,-4.0,-4.1,-4.2,-4.6,-5.1$; IR (thin film) 3522, 2956, 2931, $1728 \mathrm{~cm}^{-1}$; HRMS (ES) calcd for $\mathrm{C}_{51} \mathrm{H}_{92} \mathrm{BrIO}_{10} \mathrm{NaSi}_{4}[\mathrm{M}+\mathrm{Na}]^{+}: 1205.3893 \mathrm{~m} / \mathrm{z}$, observed: $1205.3915 \mathrm{~m} / \mathrm{z}$.

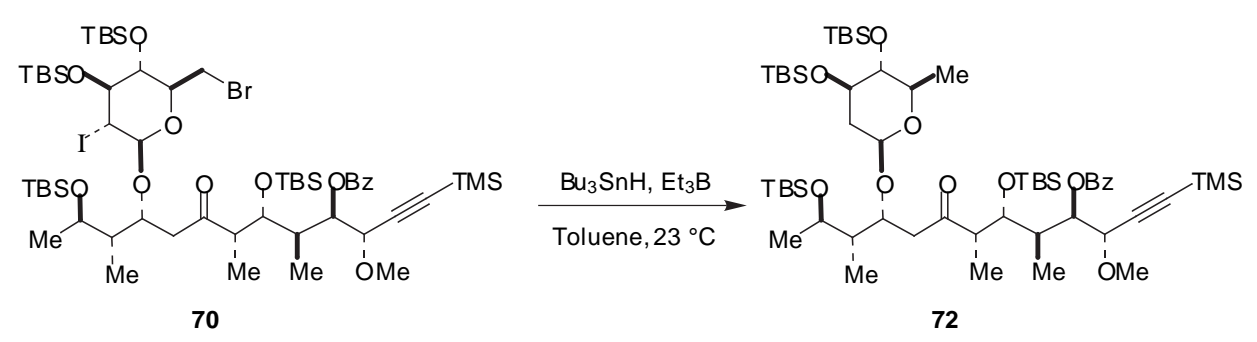


(2R, 3S, 4R, 7S, 8R, 9R, 10R, 11S)-2,8-Bis-[(tert-butyldimethyl)silyloxy]-3,7,9trimethyl-4- $O$-[2,6-deoxy-3,4-bis- $O$-(tert-butyldimethyl)silyl- $\beta$-D-glucopyranosyl)]-10-

[(benzoyl)oxy]-11-methoxy-13-trimethylsilyl-tridec-4-ol-12-yn-6-one (72). A solution of 70 $(50 \mathrm{mg}, 0.04 \mathrm{mmol})$ in toluene $(0.7 \mathrm{~mL})$ at $23^{\circ} \mathrm{C}$ was treated with $\mathrm{Bu}_{3} \mathrm{SnH}(110 \mu \mathrm{L}, 0.39 \mathrm{mmol})$ and triethylborane $(1 \mathrm{M}$ solution in hexanes, $13 \mu \mathrm{L}, 0.013 \mathrm{mmol})$. After $12 \mathrm{~h}$ at $23{ }^{\circ} \mathrm{C}$, the reaction mixture was quenched by addition of saturated $\mathrm{NaCl}$ solution and diluted with ether. The layers were separated and the organic phase dried over $\mathrm{Na}_{2} \mathrm{SO}_{4}$, filtered and concentrated The reaction mixture was filtered through silica gel (hexanes - ethyl acetate $=100: 0$ to 100:1). HPLC purification (hexanes - ethyl acetate = 97:3) of this material gave $38 \mathrm{mg}(90 \%)$ of pure 72 as a colorless oil: $[\alpha]_{\mathrm{D}}{ }^{23}=+15.7\left(c 0.51, \mathrm{CHCl}_{3}\right) ;{ }^{1} \mathrm{H} \mathrm{NMR}\left(500 \mathrm{MHz}, \mathrm{CDCl}_{3}\right) \delta 8.07(\mathrm{~d}, J=7.8$ $\mathrm{Hz}, 2 \mathrm{H}), 7.56(\mathrm{t}, J=7.4 \mathrm{~Hz}, 1 \mathrm{H}), 7.44(\mathrm{~d}, J=7.8 \mathrm{~Hz}, 2 \mathrm{H}), 5.32(\mathrm{t}, J=5.1 \mathrm{~Hz}, 1 \mathrm{H}), 4.51(\mathrm{dd}, J=$ 9.8 and $1.7 \mathrm{~Hz}, 1 \mathrm{H}), 4.35(\mathrm{td}, J=9.0$ and $3.2 \mathrm{~Hz}, 1 \mathrm{H}), 4.23(\mathrm{~d}, J=5.1 \mathrm{~Hz}, 1 \mathrm{H}), 4.08(\mathrm{dd}, J=6.1$ and $4.2 \mathrm{~Hz}, 1 \mathrm{H}), 3.94(\mathrm{p}, J=6.1 \mathrm{~Hz}, 1 \mathrm{H}), 3.58(\mathrm{~m}, 1 \mathrm{H}), 3.37(\mathrm{~s}, 3 \mathrm{H}), 3.17(\mathrm{dd}, J=8.8$ and 6.4 $\mathrm{Hz}, 1 \mathrm{H}), 3.08$ (dd apt t, $J=8.4 \mathrm{~Hz}, 1 \mathrm{H}), 2.93(\mathrm{dd}, J=17.2$ and $9.3 \mathrm{~Hz}, 1 \mathrm{H}), 2.86$ (p, $J=6.8 \mathrm{~Hz}$, $1 \mathrm{H}), 2.50(\mathrm{dd}, J=17.2$ and $3.2 \mathrm{~Hz}, 1 \mathrm{H}), 2.19(\mathrm{~m}, 1 \mathrm{H}), 1.93(\mathrm{ddd}, J=12.2,4.9$ and $1.7 \mathrm{~Hz}, 1 \mathrm{H})$, $1.44(\mathrm{~m}, 1 \mathrm{H}), 1.37(\mathrm{~m}, 1 \mathrm{H}), 1.23(\mathrm{~d}, J=6.1 \mathrm{~Hz}, 3 \mathrm{H}), 1.11(\mathrm{~d}, J=7.1 \mathrm{~Hz}, 3 \mathrm{H}), 1.09$ (d, $J=7.6$ $\mathrm{Hz}, 3 \mathrm{H}), 1.09$ (d, J = 5.9 Hz, 3H), 0.90 (s, 9H), 0.89 (s, 9H), 0.88 (s, 9H), 0.86 (d, J = 7.1 Hz, $3 \mathrm{H}), 0.84(\mathrm{~s}, 9 \mathrm{H}), 0.10(\mathrm{~s}, 9 \mathrm{H}), 0.09$ (s, 3H), 0.08 (s, 9H), 0.07 (s, 6H), $0.03(\mathrm{~s}, 3 \mathrm{H}), 0.01(\mathrm{~s}, 3 \mathrm{H})$; ${ }^{13} \mathrm{C}$ NMR (125 MHz, $\mathrm{CDCl}_{3}$ ) 211.9, 165.5, 132.8, 130.5, 129.9, 128.2, 101.1, 99.7, 92.8, 78.0, 75.8, 73.8, 73.4, 73.1, 72.9, 72.4, 69.8, 57.0, 50.3, 47.2, 45.6, 41.5, 39.6, 26.3, 26.1, 26.0, 25.9, $20.8,18.8,18.3,18.2,18.1,18.0,12.9,12.0,10.3,0.0,-0.3,-2.7,-3.0,-3.9$ (2C), -4.1 (2C), -4.6; IR (thin film) 2930, 1728, 1472, 1463, 1380, 1361, 1252, 1102, 1006, 910, 889, 837, 776, 735, 709, $674 \mathrm{~cm}^{-1}$; HRMS (ES) calcd for $\mathrm{C}_{57} \mathrm{H}_{108} \mathrm{O}_{10} \mathrm{NaSi}_{5}[\mathrm{M}+\mathrm{Na}]^{+}: 1115.6687 \mathrm{~m} / \mathrm{z}$, observed: $1115.6691 \mathrm{~m} / \mathrm{z}$. 

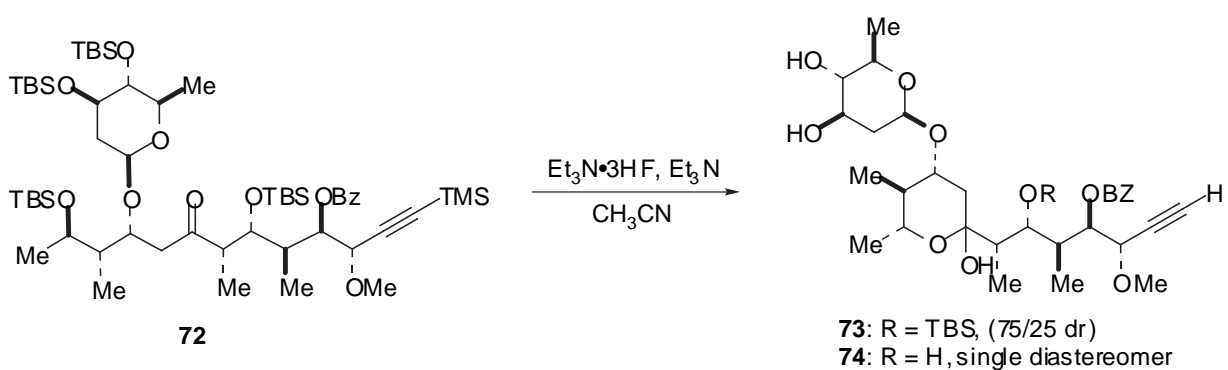

$(3 S, 4 R, 5 R, 6 R, 7 S)-4-(B e n z o y l) o x y-6-h y d r o x y-7-[(2 ' S, 4 ' R, 5 ' S, 6 ' S)-,4 '-O-(2 ', 6 '$ dideoxy- $\beta$-D-glucopyranosyl)-2-hydroxy-5,6-dimethyl-tetrahydropyranyl-2-yl]-3-methoxy5-methyl-oct-1-yne (74). To glycoside $72(13 \mathrm{mg}, 0.12 \mathrm{mmol})$ in a dry round-bottom flask under nitrogen atmosphere was added a solution of $\mathrm{Et}_{3} \mathrm{~N} \bullet 3 \mathrm{HF}\left(40 \mu \mathrm{L}, 0.25 \mathrm{mmol}^{2}\right.$ and $\mathrm{Et}_{3} \mathrm{~N}(9 \mu \mathrm{L}, 0.65$ mmol) in acetonitrile $(0.5 \mathrm{~mL})$ which had been aged for $1 \mathrm{~h}$. After $7 \mathrm{~h}$, no reaction was observed by mass spectrometry $\left(\mathrm{ES} / \mathrm{Na}^{+}\right)$analysis of the reaction mixture. $\mathrm{More}^{\mathrm{Et}} \mathrm{N}_{3} \cdot 3 \mathrm{HF}(100 \mu \mathrm{L})$ and $\mathrm{Et}_{3} \mathrm{~N}(20 \mu \mathrm{L})$ were added and the reaction was allowed to stir for $60 \mathrm{~h}$. Mass spectrometry analysis still indicated the presence of starting material. Additional $\mathrm{Et}_{3} \mathrm{~N} \bullet 3 \mathrm{HF}(100 \mu \mathrm{L})$ and $\mathrm{Et}_{3} \mathrm{~N}$ $(20 \mu \mathrm{L})$ were added and the reaction was allowed to stir for an additional $48 \mathrm{~h}$. The reaction was diluted with EtOAc, washed with $\mathrm{pH} 7.0$ buffer (x2) followed by saturated $\mathrm{NaCl}$ solution, dried over $\mathrm{MgSO}_{4}$, filtered, and concentrated. The residue was purifed by preparative TLC (10\% $\mathrm{MeOH} / \mathrm{CH}_{2} \mathrm{Cl}_{2}$ ) to provide $3.8 \mathrm{mg}$ of $\mathbf{7 3}$ as a clear oil (47\% from $\mathbf{7 2}, 75 / 25$ mixture of diastereomeric ketals) and $2.6 \mathrm{mg}$ of $\mathbf{7 4}$ as a film (39\% from $\mathbf{7 2}$ ).

Data for 74: $[\alpha]_{\mathrm{D}}{ }^{23}=-11.0\left(c 0.2, \mathrm{CH}_{2} \mathrm{Cl}_{2}\right) ;{ }^{1} \mathrm{H} \mathrm{NMR}\left(500 \mathrm{MHz}, \mathrm{CDCl}_{3}\right) \delta 8.06(\mathrm{~m}, 2 \mathrm{H})$, $7.60(\mathrm{~m}, 1 \mathrm{H}), 7.46(\mathrm{~m}, 2 \mathrm{H}), 5.48(\mathrm{dd}, J=1.5,8.5 \mathrm{~Hz}, 1 \mathrm{H}), 5.37$ (d, $J=2.50 \mathrm{~Hz}, 1 \mathrm{H}), 4.55(\mathrm{dd}, J$ $=2.0,9.5 \mathrm{~Hz}, 1 \mathrm{H}), 4.30(\mathrm{dd}, J=2.0,8.5 \mathrm{~Hz}, 1 \mathrm{H}), 4.09-4.07(\mathrm{~m}, 2 \mathrm{H}), 3.74-3.64(\mathrm{~m}, 2 \mathrm{H}), 3.60(\mathrm{~m}$, 1H), 3.48 (s, 3H), 3.26-3.20 (m, 1H), 3.09 (at, $J=9.0 \mathrm{~Hz}, 1 \mathrm{H}), 2.39$ (d, $J=2.0 \mathrm{~Hz}, 1 \mathrm{H}), 2.27$ $(\mathrm{dd}, J=5.0,12.0 \mathrm{~Hz}, 1 \mathrm{H}), 2.22(\mathrm{~m}, 1 \mathrm{H}), 2.12(\mathrm{dd}, J=2.0,5.0 \mathrm{~Hz}, 1 \mathrm{H}), 2.10(\mathrm{dd}, J=2.0,4.50$ $\mathrm{Hz}, 1 \mathrm{H}), 1.70(\mathrm{~m}, 1 \mathrm{H}), 1.60$ (dd, $J=9.5,11.5 \mathrm{~Hz}, 1 \mathrm{H}), 1.29$ (d, $J=6.0 \mathrm{~Hz}, 3 \mathrm{H}), 1.03(\mathrm{~d}, J=7.0$ $\mathrm{Hz}, 3 \mathrm{H}), 0.93(\mathrm{~d}, J=6.0 \mathrm{~Hz}, 3 \mathrm{H}), 0.92(\mathrm{~d}, J=6.5 \mathrm{~Hz}, 3 \mathrm{H}), 0.86(\mathrm{~d}, J=7.0 \mathrm{~Hz}, 3 \mathrm{H}) ;{ }^{13} \mathrm{C} \mathrm{NMR}$ $\left(125 \mathrm{MHz}, \mathrm{CDCl}_{3}\right) \delta 168.1,133.8,130.2,129.4,128.7,99.4,96.8,95.0,80.2,76.2,75.5,74.7$, 72.2, 71.5, 70.3 (2C), 69.9, 56.8, 43.6, 41.7, 40.1, 39.8, 37.0, 29.9, 19.3, 17.8, 13.3, 9.4, 7.1, 1.2; IR (thin film) 3401, $17.02 \mathrm{~cm}^{-1}$; HRMS (ES) calcd for $\mathrm{C}_{30} \mathrm{H}_{44} \mathrm{O}_{10} \mathrm{Na}[\mathrm{M}+\mathrm{Na}]^{+}: 587.2832 \mathrm{~m} / \mathrm{z}$, observed: $587.2834 \mathrm{~m} / \mathrm{z}$. 
Partial data for 73 (major diastereomer): ${ }^{1} \mathrm{H}$ NMR (500 MHz, $\left.\mathrm{CDCl}_{3}\right) \delta 8.09$ (d, $J=7.0$ $\mathrm{Hz}, 2 \mathrm{H}), 7.57$ (m, 1H), 7.45 (at, $7.5 \mathrm{~Hz}, 2 \mathrm{H}), 5.25$ (dd, 3.0, 8.5 Hz, 1H), 4.75 (d, J= 5.0 Hz, 1H), $4.55(\mathrm{dd}, J=1.5,9.5 \mathrm{~Hz}, 1 \mathrm{H}), 3.72,(\mathrm{~m}, 1 \mathrm{H}), 3.60(\mathrm{~m}, 1 \mathrm{H}), 3.47(\mathrm{~d}, J=1.5 \mathrm{~Hz}, 1 \mathrm{H}), 3.38(\mathrm{~s}, 3 \mathrm{H})$, $3.24(\mathrm{~m}, 1 \mathrm{H}), 3.10(\mathrm{t}, J=9.0 \mathrm{~Hz}, 1 \mathrm{H}), 2.54(\mathrm{~d}, J=2.0 \mathrm{~Hz}, 1 \mathrm{H}), 2.21(\mathrm{dd}, J=5.0,12.0 \mathrm{~Hz}, 1 \mathrm{H})$, $2.18(\mathrm{~m}, 1 \mathrm{H}), 2.13(\mathrm{dd}, J=5.0,12.0 \mathrm{~Hz}, 1 \mathrm{H}), 1.72(\mathrm{q}, J=7.5 \mathrm{~Hz}, 1 \mathrm{H}), 1.30(\mathrm{~d}, J=6.5 \mathrm{~Hz}, 3 \mathrm{H})$, $1.21(\mathrm{~d}, J=6.5 \mathrm{~Hz}, 3 \mathrm{H}), 1.08(\mathrm{~d}, 7.0 \mathrm{~Hz}, 3 \mathrm{H}), 1.05(\mathrm{~d}, J=7.0 \mathrm{~Hz}, 3 \mathrm{H}), 0.97$ (d, $J=6.0 \mathrm{~Hz}, 3 \mathrm{H})$, $0.92(\mathrm{~s}, 9 \mathrm{H}), 0.18(\mathrm{~s}, 3 \mathrm{H}), 0.16(\mathrm{~s}, 3 \mathrm{H})$.

\section{F. Synthesis of Formamicin.}

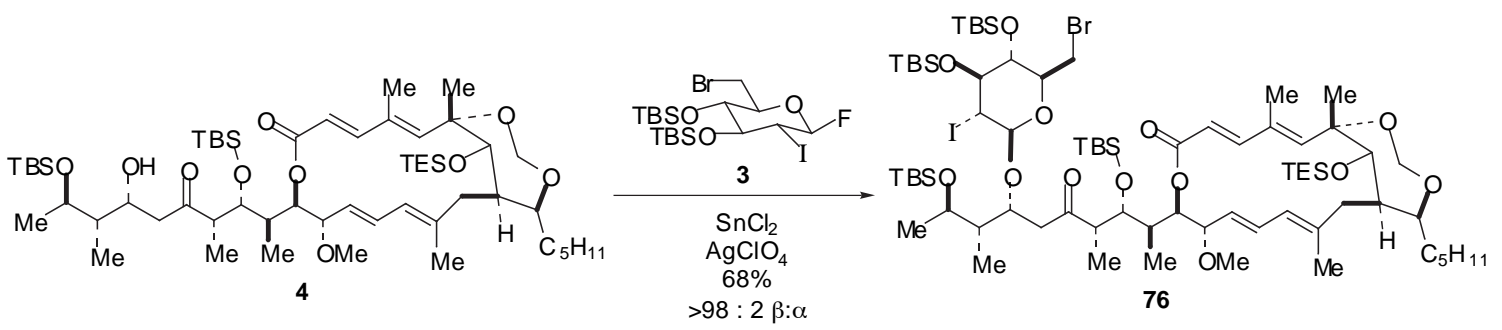

Glycoside 76. To a solution of acceptor $4(9.5 \mathrm{mg}, 0.0093 \mathrm{mmol})$ in dry ether $(0.15 \mathrm{~mL})$, under a nitrogen atmosphere, was added freshly activated $4 \AA$ MS. The resulting mixture was stirred for $5 \mathrm{~min}$ and then cooled to $-10{ }^{\circ} \mathrm{C}$. To the cooled suspension were added sequentially $\mathrm{AgClO}_{4}(24 \mathrm{mg}, 0.12 \mathrm{mmol})$ and $\mathrm{SnCl}_{2}(18 \mathrm{mg}, 0.95 \mathrm{mmol})$ and the resulting mixture was stirred for $10 \mathrm{~min}$ To the reaction was then added dropwise a solution of donor $\mathbf{3}$ (26 $\mathrm{mg}, 0.446 \mathrm{mmol}$ ) in ether $(0.1 \mathrm{~mL})$ followed by an ether rinse $(0.3 \mathrm{~mL})$. After $40 \mathrm{~min}$, the reaction mixture was filtered through a pipette fitted with a cotton plug into $\mathrm{pH}=7$ buffer solution. The diluted with ether. The aqueous layer was discarded and the organic phase was washed with $\mathrm{pH}=7$ buffer solution (x3). The aqueous washes were then combined and extracted with ether (x3). The organic extracts were then combined, washed with saturated $\mathrm{NaCl}$ solution, dried over $\mathrm{Na}_{2} \mathrm{SO}_{4}$, filtered, and concentrated. The residue was purified by preparative TLC (90:10 hexanes/EtOAc) to give glycoside 76 as a clear oil $(10 \mathrm{mg}, 68 \%)$. $[\alpha]_{\mathrm{D}}{ }^{23}=+15.1^{\circ}\left(c 0.4, \mathrm{CH}_{2} \mathrm{Cl}_{2}\right) ;{ }^{1} \mathrm{H}$ NMR $(500$ $\left.\mathrm{MHz}, \mathrm{CDCl}_{3}\right) \delta 7.10(\delta, J=15.5 \mathrm{~Hz}, 1 \mathrm{H}), 6.47(\mathrm{dd}, J=15.0,11.0 \mathrm{~Hz}, 1 \mathrm{H}), 5.78(\mathrm{~d}, J=10.5 \mathrm{~Hz}$, 1H), $5.72(\mathrm{~d}, J=16.0 \mathrm{~Hz}, 1 \mathrm{H}), 5.65(\mathrm{~s}, 1 \mathrm{H}), 5.15(\mathrm{dd}, J=9.5,15.5 \mathrm{~Hz}, 1 \mathrm{H}) 5.12(\mathrm{~d}, J=8.0 \mathrm{~Hz}$, $1 \mathrm{H}), 4.94(\mathrm{dd}, J=8.5,15.0 \mathrm{~Hz}, 1 \mathrm{H}), 4.76(\mathrm{~d}, J=8.51 \mathrm{H}), 4.46(\mathrm{~m}, 1 \mathrm{H}), 4.35(\mathrm{dd}, J=4.0,2.5 \mathrm{~Hz}$, $1 \mathrm{H}), 4.20(\mathrm{t}, J=4.0 \mathrm{~Hz}, 1 \mathrm{H}), 4.01(\mathrm{~m}, 1 \mathrm{H}), 3.93(\mathrm{~m}, 2 \mathrm{H}), 3.80(\mathrm{~d}, J=7.5 \mathrm{~Hz}, 1 \mathrm{H}), 3.70-3.60(\mathrm{~m}$, 
4H), $3.46(\mathrm{dd}, J=5.5,10.0 \mathrm{~Hz}, 1 \mathrm{H}), 3.13(\mathrm{~s}, 3 \mathrm{H}), 3.00-2.95(\mathrm{~m}, 2 \mathrm{H}), 2.71(\mathrm{~m}, 1 \mathrm{H}), 2.67(\mathrm{dd}, J=$ 5.0, 18.0 Hz, 1H), 1.98 (s, 3H), $1.96(\mathrm{~m}, 2 \mathrm{H}), 1.87$ (s, 3H), 1.69-1.40 (m, 2H), 1.39 (s, 3H), 1.38$1.26(\mathrm{~m}, 9 \mathrm{H}), 1.25(\mathrm{~s}, 3 \mathrm{H}), 1.17(\mathrm{~d}, J=7.0 \mathrm{~Hz}, 3 \mathrm{H}), 1.09$ (d, $J=6.0 \mathrm{~Hz}, 3 \mathrm{H}), 1.02$ (t, $J=9.0 \mathrm{~Hz}$, 9H), 0.99 (d, J = 7.0 Hz, 3H), 0.95 (s, 9H), 0.90 (s, 9H), 0.88 (s, 18H), 0.85 (d, J = $7.0 \mathrm{~Hz}, 3 \mathrm{H})$, 0.79-0.74 (m, 6H), 0.16 (s, 3H), 0.15 (s, 3H), 0.14 (s, 3H), 0.13 (s, 3H), 0.12 (s, 3H), 0.08 (s, 3H), 0.07 (s, 3H), $0.05(3 \mathrm{H}) ;{ }^{13} \mathrm{C} \mathrm{NMR}\left(125 \mathrm{MHz}, \mathrm{CDCl}_{3}\right) \delta 211.2,167.0,151.2,142.9,141.8$, 134.6, 132.3, 128.2, 125.3, 116.6, 99.8, 86.7, 86.4, 81.4, 80.8, 80.7, 78.9, 77.4, 75.7, 74.6, 73.7, 72.8, 72.3, 70.2, 55.9, 49.1, 47.7, 45.7, 43.2, 34.4, 33.0, 32.4, 32.1, 30.4, 29.9, 26.3, 26.2, 26.1, 25.7, 22.8, 20.8, 20.5, 18.6, 18.3 (2C), 18.1, 14.3, 13.6, 12.3, 11.5, 9.3, 7.5, 5.9, 1.2, 0.2 -3.6, $-3.7,-3.8,-3.9,-4.0(2 \mathrm{C}),-4.3,-4.4$; IR (thin film) 1707, $16.54 \mathrm{~cm}^{-1}$; HRMS (ES) calcd for $\mathrm{C}_{74} \mathrm{H}_{142} \mathrm{O}_{13} \mathrm{Si}_{5} \mathrm{Na}[\mathrm{M}+\mathrm{Na}]^{+}: 1605.7266 \mathrm{~m} / \mathrm{z}$, observed: $1605.7279 \mathrm{~m} / \mathrm{z}$.
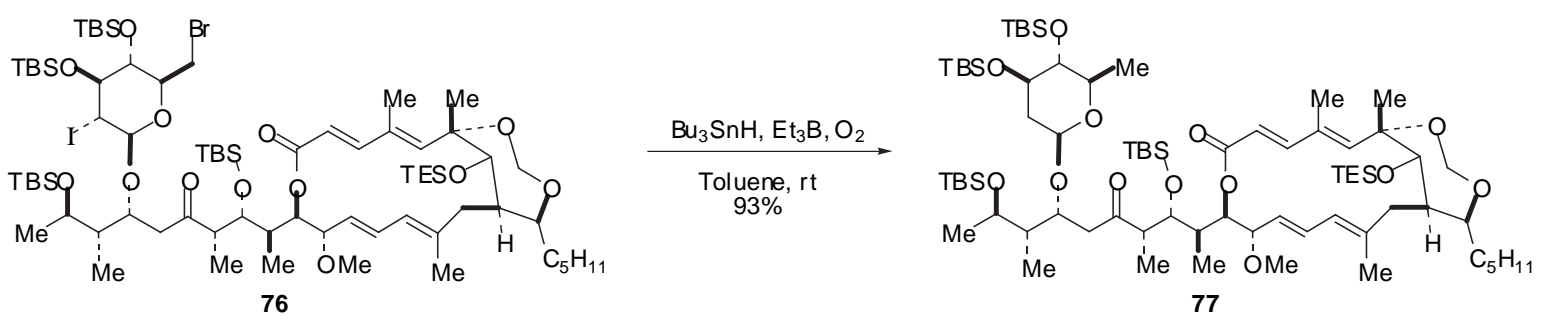

Glycoside 77. Glycoside $76(11 \mathrm{mg}, 0.0069 \mathrm{mmol})$ was dissolved in dry toluene $(0.7$ $\mathrm{mL})$. To this solution were added sequentially $\mathrm{Bu}_{3} \mathrm{SnH}(20 \mu \mathrm{L}, 0.074 \mathrm{mmol})$ and $\mathrm{Et}_{3} \mathrm{~B}(0.7 \mu \mathrm{L}, 1$ $\mathrm{M}$ in hexanes, $0.0007 \mathrm{mmol})$. Air $(1 \mathrm{~mL})$ was then sparged through the solution with a syringe and the reaction was stirred for $30 \mathrm{~min}$ The reaction was then diluted with ether and quenched with saturated $\mathrm{NaCl}$ solution. The organic layer was separated and dried over $\mathrm{Na}_{2} \mathrm{SO}_{4}$, filtered, and concentrated. The residue was purified by preparative TLC (90:10 hexanes/EtOAc) to provide glycoside $77(9 \mathrm{mg}, 94 \%)$ as a clear oil. $[\alpha]_{\mathrm{D}}{ }^{27}=-12.4^{\circ}\left(c 0.25, \mathrm{CHCl}_{3}\right) ;{ }^{1} \mathrm{H} \mathrm{NMR}(500$ $\left.\mathrm{MHz}, \mathrm{CDCl}_{3}\right) \delta 7.10(\delta, J=15.5 \mathrm{~Hz}, 1 \mathrm{H}), 6.47(\mathrm{dd}, J=11.0,15.0 \mathrm{~Hz}, 1 \mathrm{H}), 5.77(\mathrm{~d}, J=10.0$, 1H), 5.71, (d, $J=15.5 \mathrm{~Hz}, 1 \mathrm{H}), 5.65(\mathrm{~s}, 1 \mathrm{H}), 5.13(\mathrm{dd}, J=9.0,15.0 \mathrm{~Hz}, 1 \mathrm{H}), 4.93(\mathrm{dd}, J=5.5$, $8.0 \mathrm{~Hz}, 1 \mathrm{H}), 4.76(\mathrm{~d}, J=8.5 \mathrm{~Hz}, 1 \mathrm{H}), 4.69(\mathrm{~d}, 8.5 \mathrm{~Hz}, 1 \mathrm{H}), 4.50(\mathrm{dd}, J=2.0,10.0 \mathrm{~Hz}, 1 \mathrm{H}), 4.35$ $(\mathrm{dt}, J=3.0,8.0 \mathrm{~Hz}, 1 \mathrm{H}), 4.20(\mathrm{t}, J=4.5 \mathrm{~Hz}, 1 \mathrm{H}), 3.93(\mathrm{~m}, 1 \mathrm{H}), 3.80(\mathrm{~d}, J=9.0 \mathrm{~Hz}, 1 \mathrm{H}), 3.68(\mathrm{t}$, $J=8.5 \mathrm{~Hz}, 1 \mathrm{H}), 3.61(\mathrm{~m}, 1 \mathrm{H}), 3.56(\mathrm{ddd}, J=4.5,8.0,12.5 \mathrm{~Hz}, 1 \mathrm{H}), 3.17-3.13(\mathrm{~m}, 1 \mathrm{H}), 3.10$ (s, 3H), $3.07(\mathrm{t}, J=8.5 \mathrm{~Hz}, 1 \mathrm{H}), 2.99(\mathrm{~m}, 1 \mathrm{H}), 2.92(\mathrm{dd}, J=9.0,17.5 \mathrm{~Hz}, 1 \mathrm{H}), 2.71(\mathrm{~m}, 1 \mathrm{H}), 2.45$ 
$(\mathrm{dd}, J=3.0,17.5 \mathrm{~Hz}, 1 \mathrm{H}), 1.98(\mathrm{~s}, 3 \mathrm{H}), 1.95-1.90(\mathrm{~m}, 4 \mathrm{H}), 1.87(\mathrm{~s}, 3 \mathrm{H}), 1.60(\mathrm{~m}, 2 \mathrm{H}), 1.44(\mathrm{~m}$, $2 \mathrm{H}), 1.56(\mathrm{~s}, 3 \mathrm{H}), 1.36-1.24(\mathrm{~m}, 13 \mathrm{H}), 1.22(\mathrm{~d}, J=6.0 \mathrm{~Hz}, 3 \mathrm{H}), 1.08(\mathrm{~m}, 6 \mathrm{H}), 1.04-1.00(\mathrm{~m}$, $11 \mathrm{H}), 0.92-0.84(\mathrm{~m}, 36 \mathrm{H}), 0.79-0.69(\mathrm{~m}, 6 \mathrm{H}), 0.12(\mathrm{~s}, 3 \mathrm{H}), 0.09(\mathrm{~s}, 6 \mathrm{H}), 0.07$ (s, 9H), 0.06 (s, 3H), $0.05(\mathrm{~s}, 3 \mathrm{H}) ;{ }^{13} \mathrm{C}$ NMR $\left(125 \mathrm{MHz}, \mathrm{CDCl}_{3}\right) \delta 212.5,167.0,151.2,143.0,141.8,134.5$, $132.4,127.9,125.3,116.5,99.6,86.6,81.41,78.9,78.3,75.8,75.7,74.4,73.4,72.8,72.6,70.0$, 55.8, 49.2, 47.8, 47.2, 45.9, 43.3, 41.8, 34.5, 32.1, 30.6, 30.4, 26.6, 26.4, 26.3, 26.2, 26.1, 25.7, $22.9,20.5,19.1,18.6,18.5,18.3$ (2C), 14.3, 12.9, 12.3, 11.5, 10.4, 7.5, 7.4, 6.0, 5.5, -2.4, -2.8, $-3.6,-3.7,-3.8,-3.9,-4.3$; IR (thin film) 1716, 1494, $1264 \mathrm{~cm}^{-1}$; HRMS (ES) calcd for $\mathrm{C}_{74} \mathrm{H}_{142} \mathrm{O}_{13} \mathrm{Si}_{5} \mathrm{Na}[\mathrm{M}+\mathrm{Na}]^{+}: 1401.9195 \mathrm{~m} / \mathrm{z}$, observed: $1401.9175 \mathrm{~m} / \mathrm{z}$.
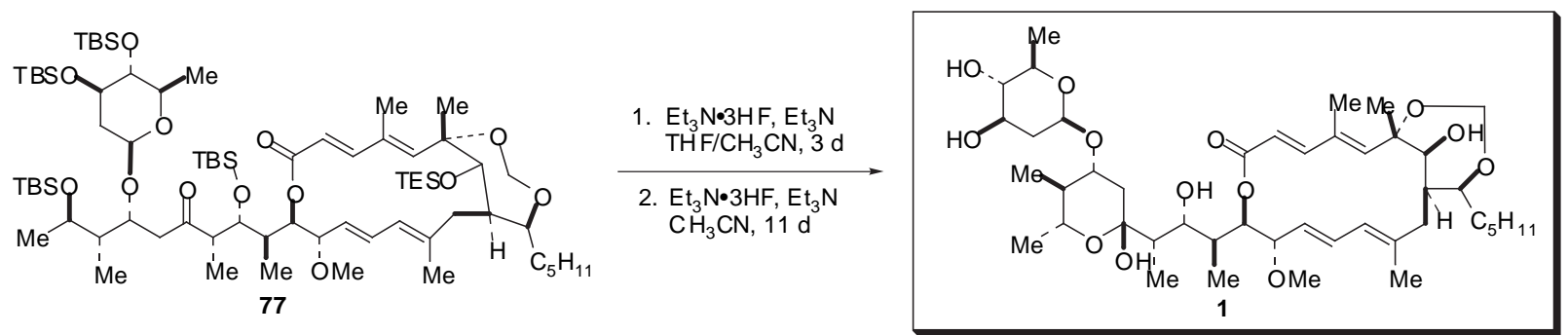

Formamicin (1). Glycoside $77(4.3 \mathrm{mg}, 0.0031 \mathrm{mmol})$ was dissolved in dry THF $(0.7$ $\mathrm{mL})$ under a nitrogen atmosphere. To this solution was added dry $\mathrm{CH}_{3} \mathrm{CN}(0.7 \mathrm{~mL})$. The resulting solution was then treated with $\mathrm{Et}_{3} \mathrm{~N} \cdot 3 \mathrm{HF}(0.8 \mathrm{~mL}, 4.9 \mathrm{mmol}$, Aldrich) dropwise. During this addition the solution became slightly cloudy. To this mixture was then added $\mathrm{Et}_{3} \mathrm{~N}(0.14 \mathrm{~mL}$, $1.0 \mathrm{mmol}$ ) slowly via syringe. The resulting mixture was stirred at ambient temperature for $72 \mathrm{~h}$. The reaction mixture was then diluted with ether $(50 \mathrm{~mL})$ and washed with $\mathrm{pH}=7$ buffer solution $(30 \mathrm{~mL} \times 4)$ and saturated $\mathrm{NaCl}$ solution. The organic phase was dried over $\mathrm{Na}_{2} \mathrm{SO}_{4}(15$ g) and $\mathrm{KHCO}_{3}(10 \mathrm{~g})^{17}$ for $1.5 \mathrm{~h}$, filtered, and the volume of the reaction mixture was concentrated to $\sim 10 \mathrm{~mL}$. $\mathrm{Na}_{2} \mathrm{SO}_{4}$ was added to remove residual water and the solution was again filtered and then concentrated to dryness to give $\sim 4.6 \mathrm{mg}$ of a film. This material (a mixture of mono TBS ether ketals) was used without further purification in the next step.

The residue from the previous reaction was dissolved in dry $\mathrm{CH}_{3} \mathrm{CN}(0.8 \mathrm{~mL})$ under a nitrogen atmosphere. The resulting solution was then treated with $\mathrm{Et}_{3} \mathrm{~N} \cdot 3 \mathrm{HF}(0.8 \mathrm{~mL}, 4.9 \mathrm{mmol})$ dropwise. To this mixture was then added $\mathrm{Et}_{3} \mathrm{~N}(0.15 \mathrm{~mL}, 1.1 \mathrm{mmol})$ slowly via syringe. The resulting mixture was stirred at ambient temperature for 11 days. The reaction mixture was then 
diluted with ether $(50 \mathrm{~mL})$ and washed with $\mathrm{pH}=7$ buffer solution $(30 \mathrm{~mL}$ x 4$)$, saturated $\mathrm{NaCl}$ solution, dried over $\mathrm{Na}_{2} \mathrm{SO}_{4}(10 \mathrm{~g})$ and $\mathrm{KHCO}_{3}(10 \mathrm{~g})$ for $1.5 \mathrm{~h}$, filtered, and the volume of the reaction mixture was concentrated to $\sim 10 \mathrm{~mL}$. $\mathrm{Na}_{2} \mathrm{SO}_{4}$ was added to remove residual water and the solution was again filtered and then concentrated to dryness. The residue was purified by preparative TLC (4:1 EtOAc/ $\left.\mathrm{CHCl}_{3}\right)$ to give $1(1.5 \mathrm{mg}, 60 \%$ from 77) as a yellow oil. This material had a slight amount of an impurity that appeared as a broad multiplet at 5.38-5.28 ppm in the ${ }^{1} \mathrm{H}$ NMR spectrum. This material could not be removed under a variety of flash chromatography, normal-phase HPLC, or reverse-phase HPLC conditions. However, dissolution of the slightly impure material in acetonitrile and washing with hexanes (x8) provided an analytical sample of $\mathbf{1}(0.4 \mathrm{mg}, 16 \%$ from 77$)$.

\section{Analytical Data for Synthetic Formamicin}

Comparison of synthetic $\mathbf{1}$ to a sample of natural $\mathbf{1}$ supplied by Igarashi et al ${ }^{18,19}$ showed synthetic 1 to be identical to natural 1. Tabulated spectroscopic data, ${ }^{1} \mathrm{H}$ NMR spectra of synthetic and natural $\mathbf{1}$, as well as ${ }^{13} \mathrm{C}$ NMR spectra of synthetic $\mathbf{1}$ are provided on the following pages.

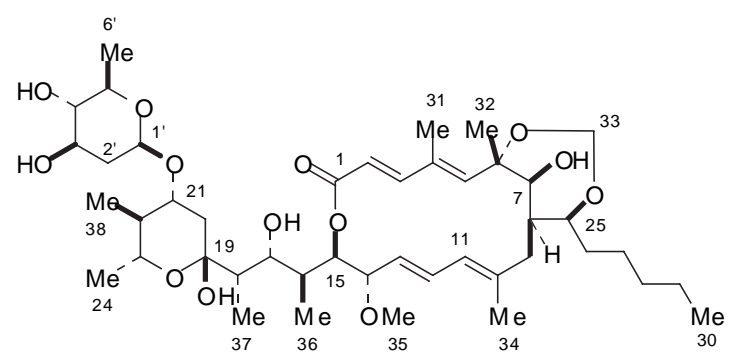

Figure 1. Formamicin Numbering System. 
Table 1. ${ }^{1}$ H NMR Data for Synthetic and Natural Formamicin (1).

$$
\text { Natural Formamicin Synthetic Formamicin }
$$

Position ${ }^{1} \mathrm{H}(500 \mathrm{MHz}) \delta$ Multiplicity $(J$ in $\mathrm{Hz}) \# \mathrm{H}^{1} \mathrm{H}(500 \mathrm{MHz}) \delta$ Multiplicity $(J$ in Hz) \#H Difference $(\Delta \delta)$

\begin{tabular}{|c|c|c|c|c|c|c|c|}
\hline 3 & 7.22 & $d(16.0)$ & 1 & 7.22 & $d(16.0)$ & 1 & 0 \\
\hline 12 & 6.49 & $d d(11.0,15.0)$ & 1 & 6.49 & $d d(10.5,15.0)$ & 1 & 0 \\
\hline 11 & 5.71 & $d(11.0)$ & 1 & 5.71 & $d(10.0)$ & 1 & 0 \\
\hline $19-\mathrm{OH}$ & 5.68 & $\mathrm{~s}$ & 1 & 5.67 & $s$ & 1 & 0.01 \\
\hline 5 & 5.67 & $\mathrm{~d}(2.0)^{\mathrm{a}}$ & 1 & 5.67 & s & 1 & 0 \\
\hline 2 & 5.65 & $d(15.5)$ & 1 & 5.65 & $d(16.0)$ & 1 & 0 \\
\hline 13 & 5.15 & $\mathrm{dd}(9.5,15.0)$ & 1 & 5.15 & dd $(9.5,15.0)$ & 1 & 0 \\
\hline 15 & 4.91 & $d(9.0)$ & 1 & 4.91 & $d(9.0)$ & 1 & 0 \\
\hline $17-\mathrm{OH}$ & 4.80 & $d(4.0)$ & 1 & 4.80 & $d(4.0)$ & 1 & 0 \\
\hline 33 & 4.69 & $d(8.5)$ & 1 & 4.68 & $d(8.5)$ & 1 & 0.01 \\
\hline 33 & 4.58 & $d(8.5)$ & 1 & 4.58 & $d(8.5)$ & 1 & 0 \\
\hline $1^{\prime}$ & 4.48 & $\mathrm{dd}(1.5,9.5)$ & 1 & 4.48 & $d d(1.5,9.5)$ & 1 & 0 \\
\hline 17 & 4.15 & ddd $(1.5,3.5,11.0)$ & 1 & 4.15 & ddd $(1.5,4.0,10.0)$ & 1 & 0 \\
\hline 14 & 3.86 & $\mathrm{t}(9.5)$ & 1 & 3.86 & $\mathrm{t}(9.5)$ & 1 & 0 \\
\hline 21 & $3.78-3.70$ & $\mathrm{~m}$ & 1 & $3.77-3.71$ & $\mathrm{~m}$ & 1 & - \\
\hline 23 & $3.78-3.70$ & $\mathrm{~m}$ & 1 & $3.77-3.71$ & $\mathrm{~m}$ & 1 & - \\
\hline 25 & 3.56 & $\mathrm{~m}$ & 1 & 3.57 & $\mathrm{~m}$ & 1 & -0.01 \\
\hline 7 & 3.51 & $\mathrm{dd}(5.0,8.0)$ & 1 & 3.51 & dd $(5.5,8.5)$ & 1 & 0 \\
\hline $3^{\prime}$ & 3.39 & $\mathrm{~m}$ & 1 & 3.39 & $\mathrm{~m}$ & 1 & 0 \\
\hline 35 & 3.18 & $\mathrm{~s}$ & 3 & 3.18 & s & 3 & 0 \\
\hline $5^{\prime}$ & 3.10 & $\mathrm{~m}$ & 1 & 3.10 & $\mathrm{~m}$ & 1 & 0 \\
\hline $4^{\prime}$ & 2.91 & $\mathrm{t}(9.0)$ & 1 & 2.91 & $t(8.0)$ & 1 & 0 \\
\hline 8 & 2.60 & $\mathrm{~m}$ & 1 & 2.60 & $\mathrm{~m}$ & 1 & 0 \\
\hline 20 & 2.29 & $\mathrm{dd}(4.5,11.5)$ & 1 & 2.29 & $\mathrm{dd}(4.5,11.5)$ & 1 & 0 \\
\hline 16 & $2.26-2.18$ & $\mathrm{~m}$ & 1 & $2.27-2.18$ & $\mathrm{~m}$ & 1 & - \\
\hline 3'-OH & 2.15 & $\mathrm{~m}$ & 1 & 2.15 & ddd $(8.0,14.5,17.0)$ & 1 & 0 \\
\hline 4'-OH & 2.00 & ddd $(2.0,3.5,12.0)$ & 1 & 2.01 & ddd $(2.0,4.5,12.0)$ & 1 & -0.01 \\
\hline $2^{\prime}$ & 1.97 & $\mathrm{~m}$ & 1 & 1.97 & $\mathrm{~m}$ & 1 & 0 \\
\hline 9 & 1.92 & $d(14.5)$ & 1 & 1.92 & $d(13.5)$ & 1 & 0 \\
\hline 34 & 1.89 & $\mathrm{~s}$ & 3 & 1.89 & s & 3 & 0 \\
\hline 9 & 1.78 & $s$ & 3 & 1.77 & $d(7.5)$ & 3 & 0.01 \\
\hline 31 & $1.76-1.70$ & $\mathrm{~m}$ & 1 & $1.76-1.71$ & $\mathrm{~m}$ & 1 & - \\
\hline 18 & $1.76-1.70$ & $\mathrm{~m}$ & 1 & $1.76-1.71$ & $\mathrm{~m}$ & 1 & - \\
\hline $7-\mathrm{OH}$ & 1.58 & $\mathrm{~m}$ & 1 & 1.58 & $\mathrm{~m}$ & 1 & 0 \\
\hline $2^{\prime}$ & $1.56-1.49$ & $\mathrm{~m}$ & 1 & $1.55-1.49$ & $\mathrm{~m}$ & 1 & - \\
\hline 32 & 1.42 & $d(5.0)$ & 1 & 1.42 & $d(5.5)$ & 1 & 0 \\
\hline 28 & 1.28 & $\mathrm{~s}$ & 3 & 1.28 & $\mathrm{~s}$ & 3 & 0 \\
\hline 29 & $1.27-1.18$ & $\mathrm{~m}$ & 2 & $1.27-1.19$ & $\mathrm{~m}$ & 2 & - \\
\hline 27 & $1.27-1.18$ & $\mathrm{~m}$ & 2 & $1.27-1.19$ & $\mathrm{~m}$ & 2 & - \\
\hline 26 & $1.27-1.18$ & $\mathrm{~m}$ & 2 & $1.27-1.19$ & $\mathrm{~m}$ & 2 & - \\
\hline 22 & $1.27-1.18$ & $\mathrm{~m}$ & 2 & $1.27-1.19$ & $\mathrm{~m}$ & 2 & - \\
\hline $6^{\prime}$ & 1.20 & $d(6.5)$ & 3 & 1.19 & $d(6.5)$ & 3 & 0.01 \\
\hline 20 & $1.14^{b}$ & $\mathrm{~m}$ & 1 & $1.13^{b}$ & $\mathrm{~m}$ & 1 & - \\
\hline 24 & 1.10 & $d(6.5)$ & 3 & 1.10 & $d(6.5)$ & 3 & 0 \\
\hline 37 & 1.03 & $d(7.5)$ & 3 & 1.03 & $d(7.0)$ & 3 & 0 \\
\hline 38 & 0.94 & $d(7.5)$ & 3 & 0.94 & $d(6.5)$ & 3 & 0 \\
\hline 30 & 0.86 & $\mathrm{t}(7.0)$ & 3 & 0.86 & $\mathrm{t}(7.5)$ & 3 & 0 \\
\hline 36 & 0.78 & $d(7.0)$ & 3 & 0.78 & $d(6.5)$ & 3 & 0 \\
\hline
\end{tabular}

Total number of $\mathrm{H}=\mathbf{7 2}$

Total number of $\mathrm{H}=\mathbf{7 2}$

${ }^{a}$ Igarashi et al report this resonance at $5.71 \mathrm{ppm}(\mathrm{s}, 1 \mathrm{H})$ (see ref. 19). We also observed that this peak would overlap with $\mathrm{C}(19)-\mathrm{OH}$ in certain samples. ${ }^{b}$ Obscured by $\mathrm{H}_{2} \mathrm{O}$. 
Table 2. ${ }^{13} \mathrm{C}$ NMR Data for Synthetic and Natural Formamicin (1).

\begin{tabular}{|c|c|c|c|}
\hline & $\begin{array}{c}\text { Natural } \\
\text { Formamicin }\end{array}$ & $\begin{array}{c}\text { Synthetic } \\
\text { Formamicin }^{b}\end{array}$ & \\
\hline Position & ${ }^{13} \mathrm{C}(125 \mathrm{MHz}) \delta$ & ${ }^{13} \mathrm{C}(125 \mathrm{MHz}) \delta$ & Difference $(\Delta \delta)$ \\
\hline 1 & 169.6 & 169.7 & -0.1 \\
\hline 3 & 153.8 & 153.9 & -0.1 \\
\hline 10 & 143.4 & 143.5 & -0.1 \\
\hline 5 & 142.6 & 142.7 & -0.1 \\
\hline 4 & 134.6 & 134.8 & -0.2 \\
\hline 12 & 132.9 & 133 & -0.1 \\
\hline 13 & 127.8 & 128 & -0.2 \\
\hline 11 & 125.3 & 125.5 & -0.2 \\
\hline 2 & 115.0 & 115.2 & -0.2 \\
\hline 19 & 99.4 & 99.6 & -0.2 \\
\hline $1^{\prime}$ & 96.8 & 96.9 & -0.1 \\
\hline 33 & 86.5 & 86.7 & -0.2 \\
\hline 14 & 82.3 & 82.4 & -0.1 \\
\hline 6 & 80.1 & 80.2 & -0.1 \\
\hline 25 & 78.0 & 78.1 & -0.1 \\
\hline $4^{\prime}$ & 77.9 & 78 & -0.1 \\
\hline 21 & 76.2 & 76.3 & -0.1 \\
\hline 15 & 75.8 & 76 & -0.2 \\
\hline 7 & 74.8 & 75 & -0.2 \\
\hline $3^{\prime}$ & 72.0 & 72.2 & -0.2 \\
\hline $5^{\prime}$ & 71.4 & 71.5 & -0.1 \\
\hline 17 & 70.5 & 70.6 & -0.1 \\
\hline 23 & 69.8 & 69.9 & -0.1 \\
\hline 35 & 55.7 & 55.8 & -0.1 \\
\hline 8 & 47.2 & 47.3 & -0.1 \\
\hline 22 & 43.7 & 43.8 & -0.1 \\
\hline 18 & 41.9 & 42 & -0.1 \\
\hline 20 & 40.2 & 40.4 & -0.2 \\
\hline $2^{\prime}$ & 39.7 & 39.9 & -0.2 \\
\hline 16 & 37.3 & 37.5 & -0.2 \\
\hline 9 & 34.8 & 34.9 & -0.1 \\
\hline 28 & 32.0 & 32.2 & -0.2 \\
\hline 26 & 30.2 & 30.3 & -0.1 \\
\hline 27 & 25.8 & 26 & -0.2 \\
\hline 32 & 24.9 & 25.1 & -0.2 \\
\hline 29 & 22.8 & 22.9 & -0.1 \\
\hline 34 & 20.2 & 20.3 & -0.1 \\
\hline 24 & 19.5 & 19.7 & -0.2 \\
\hline $6^{\prime}$ & 17.7 & 17.8 & -0.1 \\
\hline 30 & 14.2 & 14.3 & -0.1 \\
\hline 38 & 13.3 & 13.5 & -0.2 \\
\hline 31 & 11.7 & 11.9 & -0.2 \\
\hline 36 & 9.7 & 9.9 & -0.2 \\
\hline 37 & 7.3 & 7.4 & -0.1 \\
\hline
\end{tabular}


Table 3. Other Analytical Data for Synthetic and Natural Formamicin (1).

\begin{tabular}{|c|c|c|}
\hline Method & Natural Formamicin & Synthetic Formamicin \\
\hline \multicolumn{3}{|c|}{ Optical Rotation $[\alpha]_{D}^{27}=-31^{\circ}\left(c 0.08, \mathrm{CHCl}_{3}\right)[\alpha]_{D}^{27}=-36^{\circ}\left(c 0.1, \mathrm{CHCl}_{3}\right)$} \\
\hline $\mathrm{HRMS}^{a}$ & $\begin{array}{c}\text { HRMS (FAB) calcd for } \\
\mathrm{C}_{44} \mathrm{H}_{72} \mathrm{O}_{13} \mathrm{Na}[\mathrm{M}+\mathrm{Na}]^{+}: \\
831.4871 \mathrm{~m} / \mathrm{z} \\
\text { observed: } 831.4859 \mathrm{~m} / \mathrm{z}\end{array}$ & $\begin{array}{c}\text { HRMS (ES) calcd for } \\
\mathrm{C}_{44} \mathrm{H}_{72} \mathrm{O}_{13} \mathrm{Na}[\mathrm{M}+\mathrm{Na}]^{+}: \\
831.4871 \mathrm{~m} / \mathrm{z} \\
\text { observed: } 831.4891 \mathrm{~m} / \mathrm{z}\end{array}$ \\
\hline \multirow[t]{5}{*}{$\mathrm{IR}^{a}$} & $\mathrm{~cm}^{-1}(\mathrm{KBr})$ & $\mathrm{cm}^{-1}$ (thin film) \\
\hline & 3423 & 3419 \\
\hline & 2933 & 2924 \\
\hline & 1685 & 1683 \\
\hline & 1452 & 1455 \\
\hline
\end{tabular}

aPublished data from Igarashi et al are reported here. See reference 19. 


\section{REFERENCES.}

(1) Pangborn, A. B.; Giardello, M. A.; Grubbs, R. H.; Rosen, R. K.; Timmers, F. J. Organometallics 1996, 15, 1518.

(2) Panek, J. S.; Sparks, M. A. J. Org. Chem. 1989, 54, 2034.

(3) Calter, P.; Evans, D. A. Ph. D. Thesis, Harvard University, 1993.

(4) Powell, N. A.; Roush, W. R. Org. Lett. 2001, 3, 453.

(5) Srogl, J.; Allred, G. D.; Liebeskind, L. S. J. Am. Chem. Soc. 1997, 119, 12376.

(6) Dixon, D. J.; Ley, S. V.; Longbottom, D. A. J. Chem. Soc., Perkin Trans. 1 1999, 2231.

(7) Allred, G. D.; Liebeskind, L. S. J. Am. Chem. Soc. 1996, 118, 2748.

(8) Savall, B. M.; Powell, N. A.; Roush, W. R. Org. Lett. 2001, 3, 3057.

(9) Scheidt, K. A.; Bannister, T. D.; Tasaka, A.; Wendt, M. D.; Savall, B. M.; Fegley, G. J.; Roush, W. R. J. Am. Chem. Soc. 2002, 124, 6981.

(10) Bestmann, H. J.; Liepold, B.; Kress, A.; Hoffmann, A. Chem. Eur. J. 1999, 5, 2984.

(11) Roush, W. R.; Bennett, C. E. J. Am. Chem. Soc. 1999, 121, 3541.

(12) Garegg, P. J.; Hultberg, H.; Wallin, S. Carbohydrate Res. 1982, 108, 97.

(13) Roush, W. R.; Gung, B. W.; Bennett, C. E. Org. Lett. 1999, 1, 891.

(14) Bennett, C. E. Ph.D. Thesis, Indiana University, Bloomington, IN, 2000.

(15) Dess, D. B.; Martin, J. C. J. Org. Chem. 1983, 48, 4155. 
(16) Meyer, S. D.; Schreiber, S. L. J. Org. Chem. 1994, 59, 7549.

(17) Shotwell, J. B.; Hu, S.; Medina, E.; Abe, M.; Cole, R.; Crews, C. M.; Wood, J. L. Tetrahedron Lett. 2000, 41, 9639; see reference14 therein.

(18) Igarashi, M.; Kinoshita, N.; Ikeda, T.; Nakagawa, E.; Hamada, M.; Takeuchi, T. J. Antibiot. 1997, 50, 926.

(19) Igarashi, M.; Nakamura, H.; Naganawa, H.; Takeuchi, T. J. Antibiot. 1997, 50, 932. Correction: J. Antiobiot. 1998, 51, C1.

(20) Gottlieb, H. E.; Kotlyar, V.; Nudelman, A. J. Org. Chem. 1997, 62, 7512-7515. 


\section{${ }^{1} \mathrm{H}$ AND ${ }^{13} \mathrm{C}$ NMR Spectra for Synthetic and Natural Formamicin.}




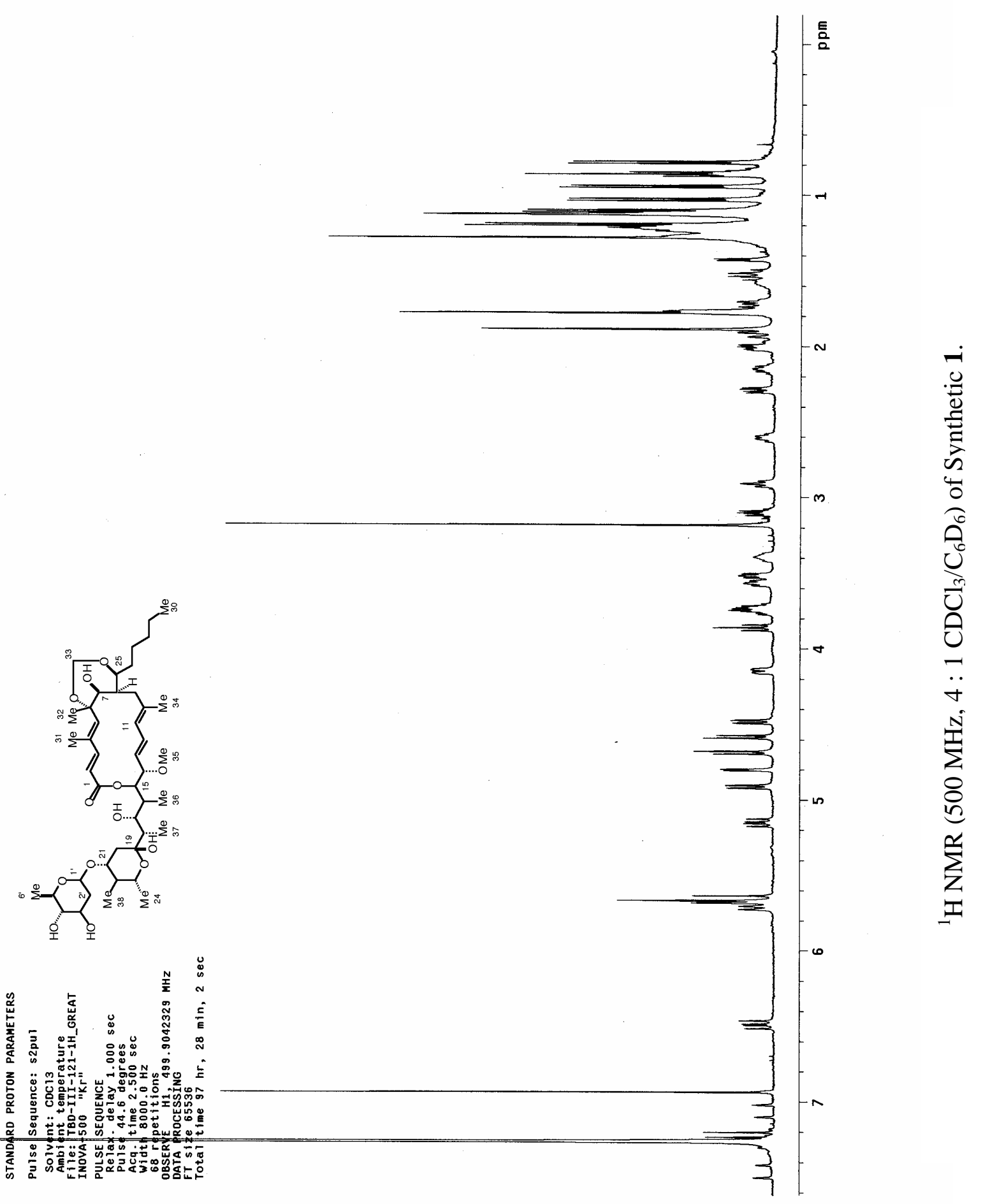




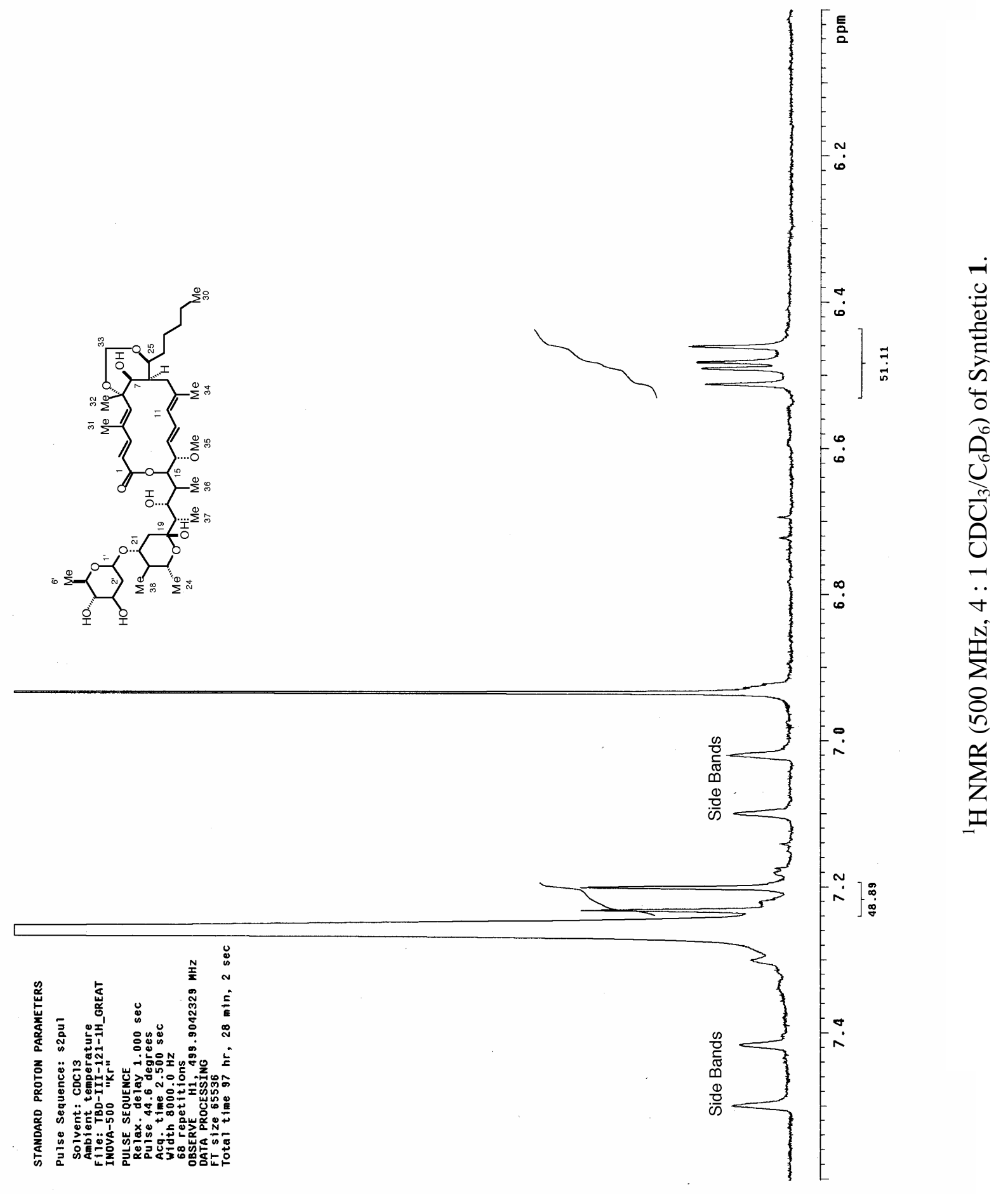




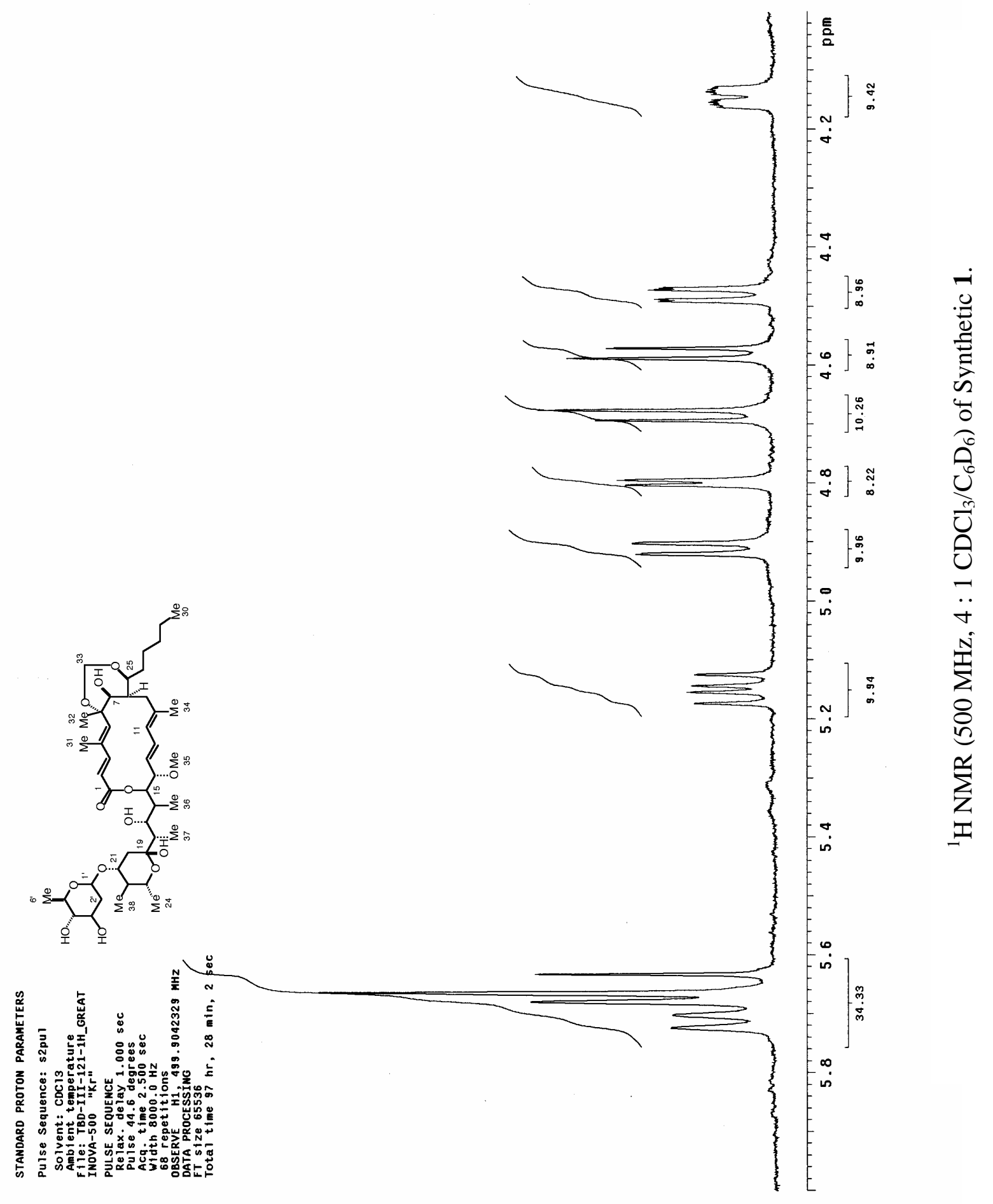




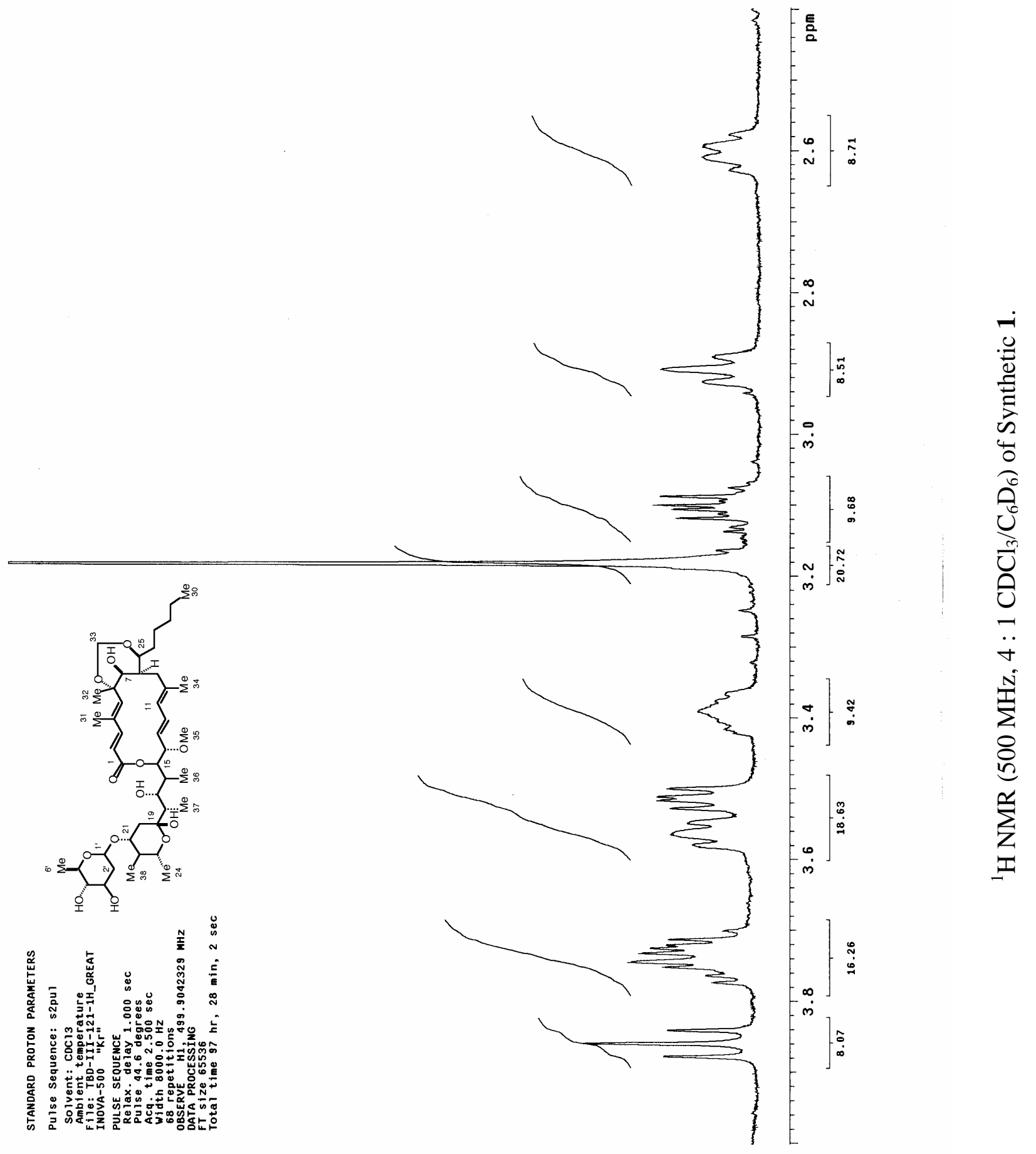



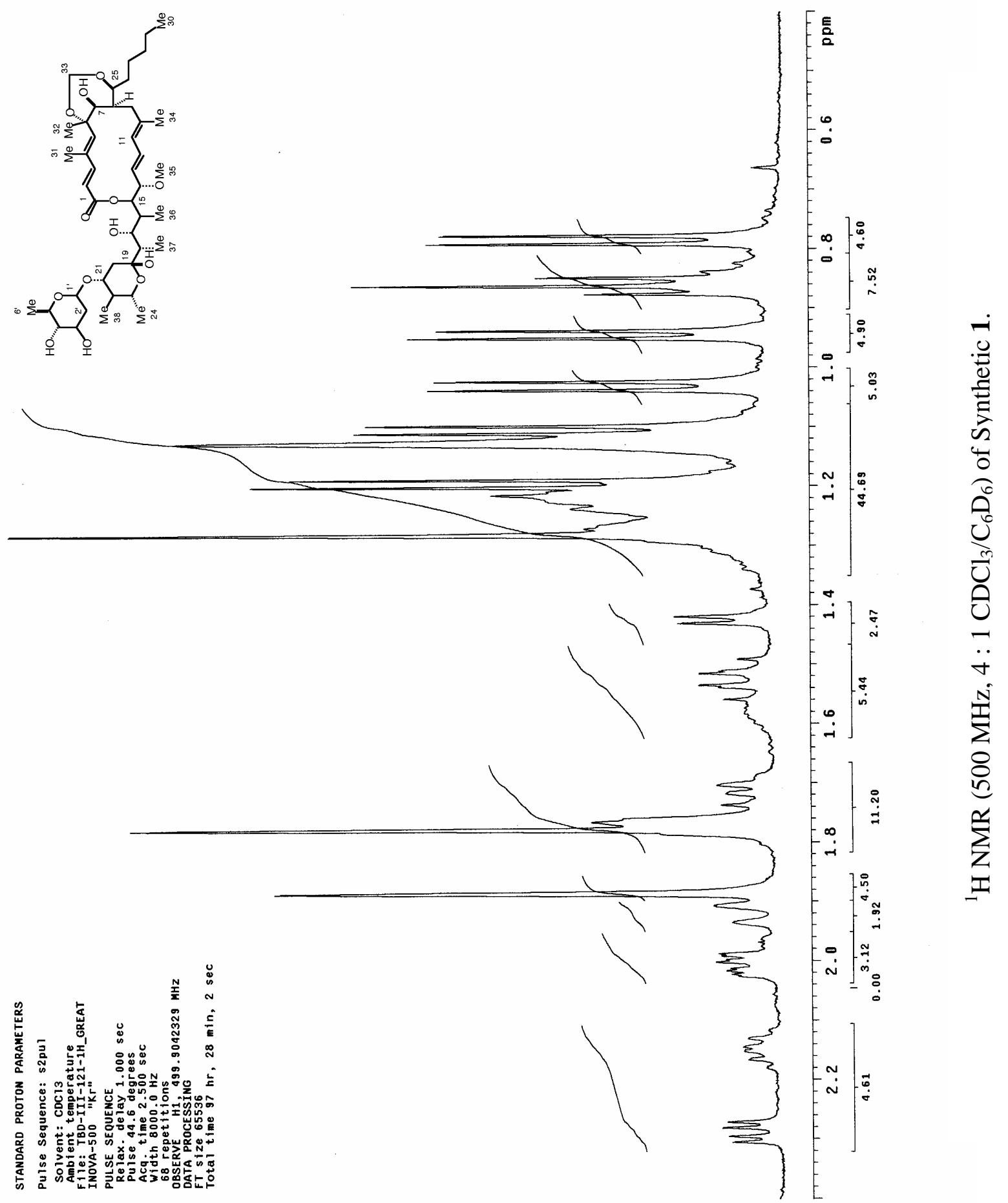


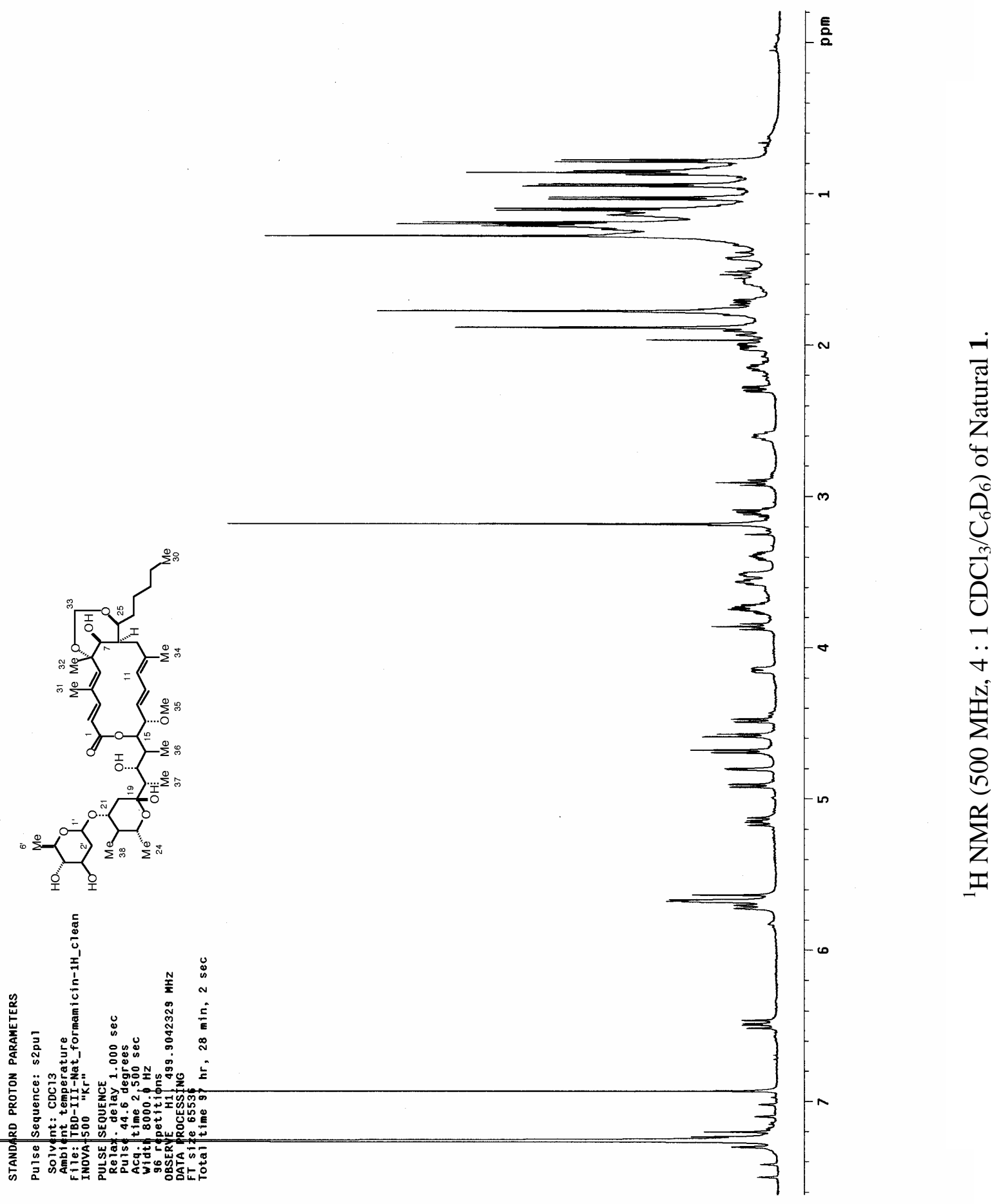




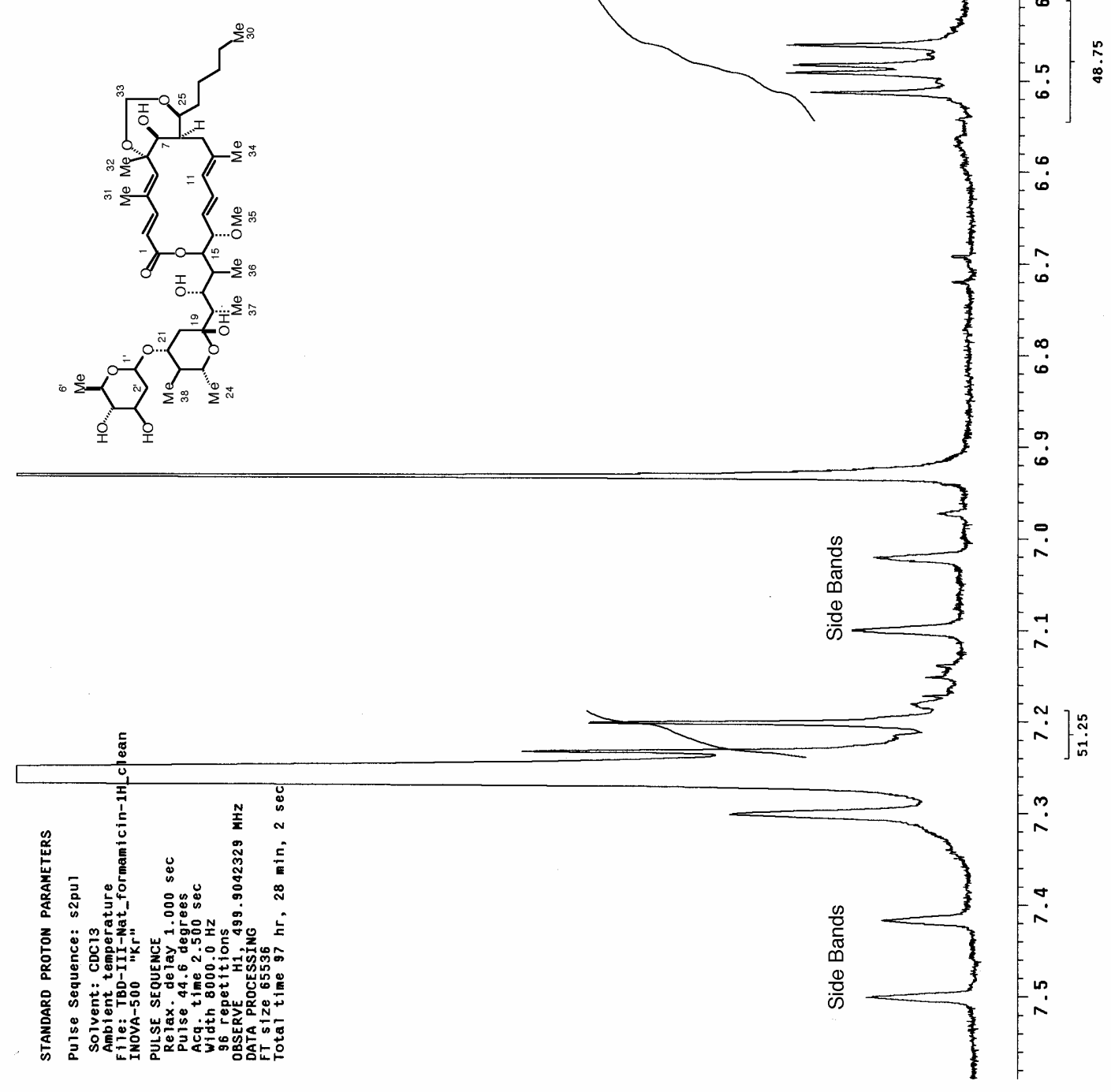

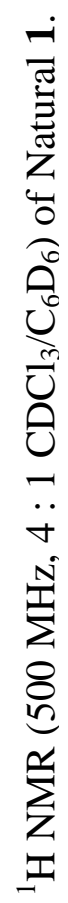




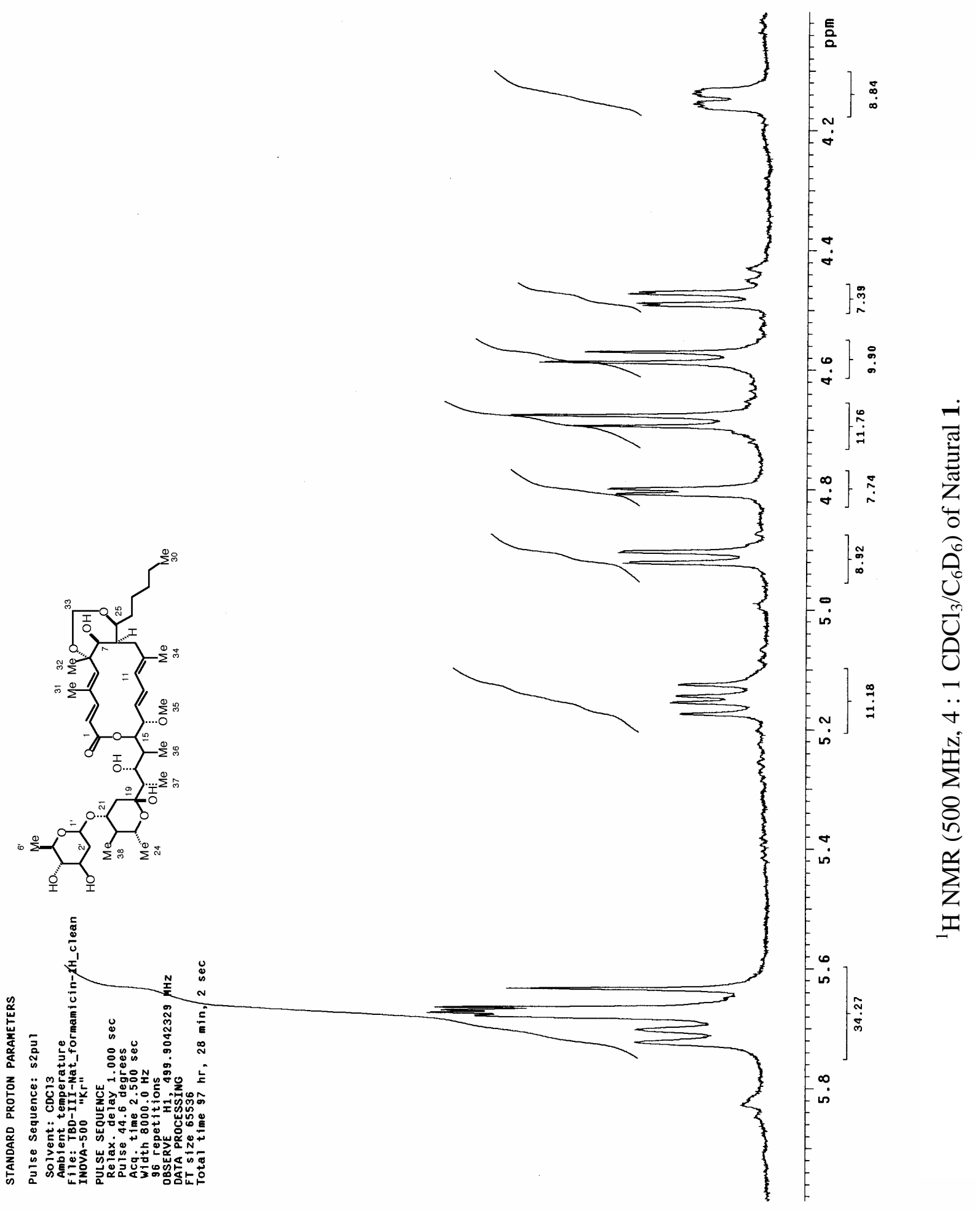




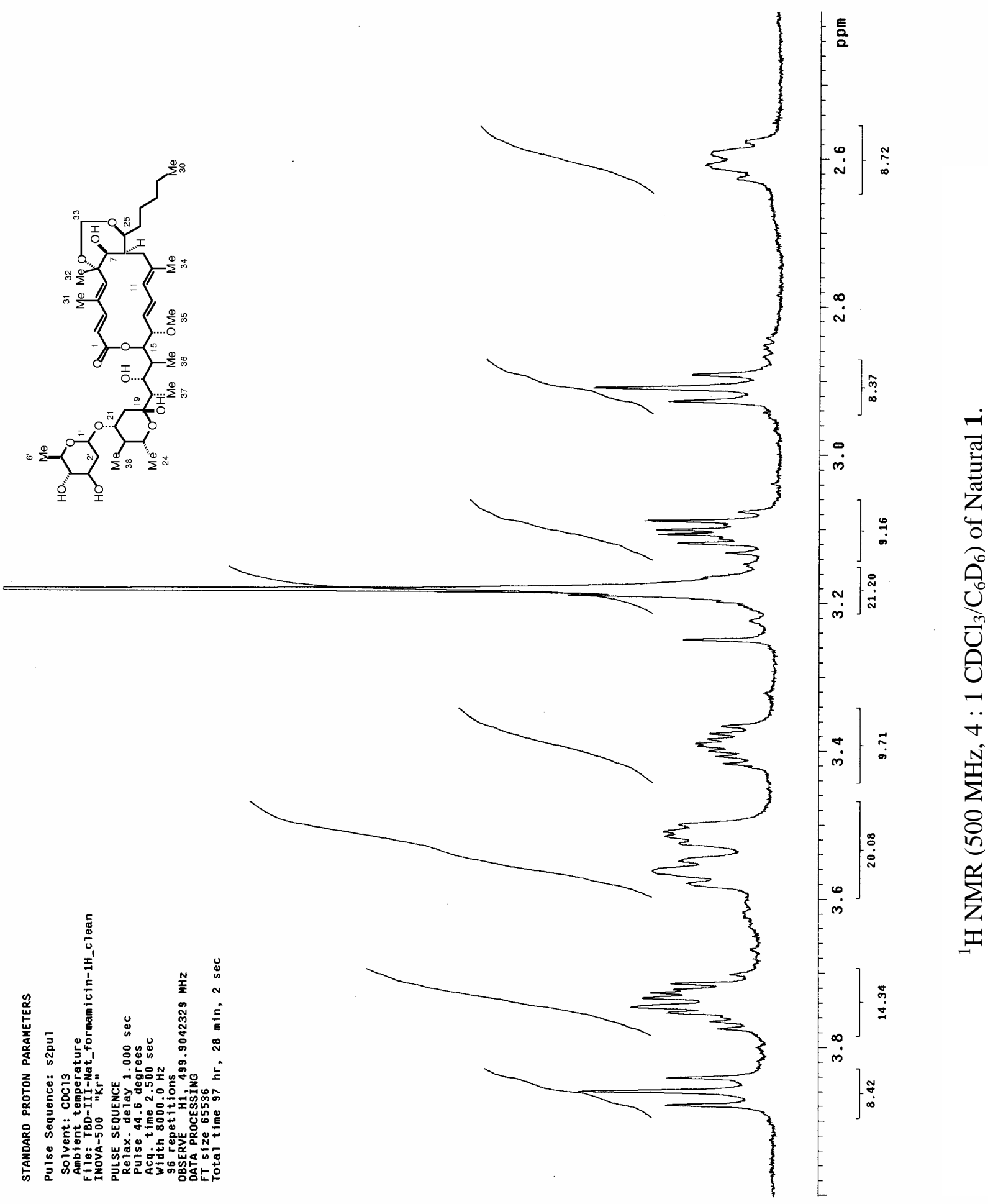




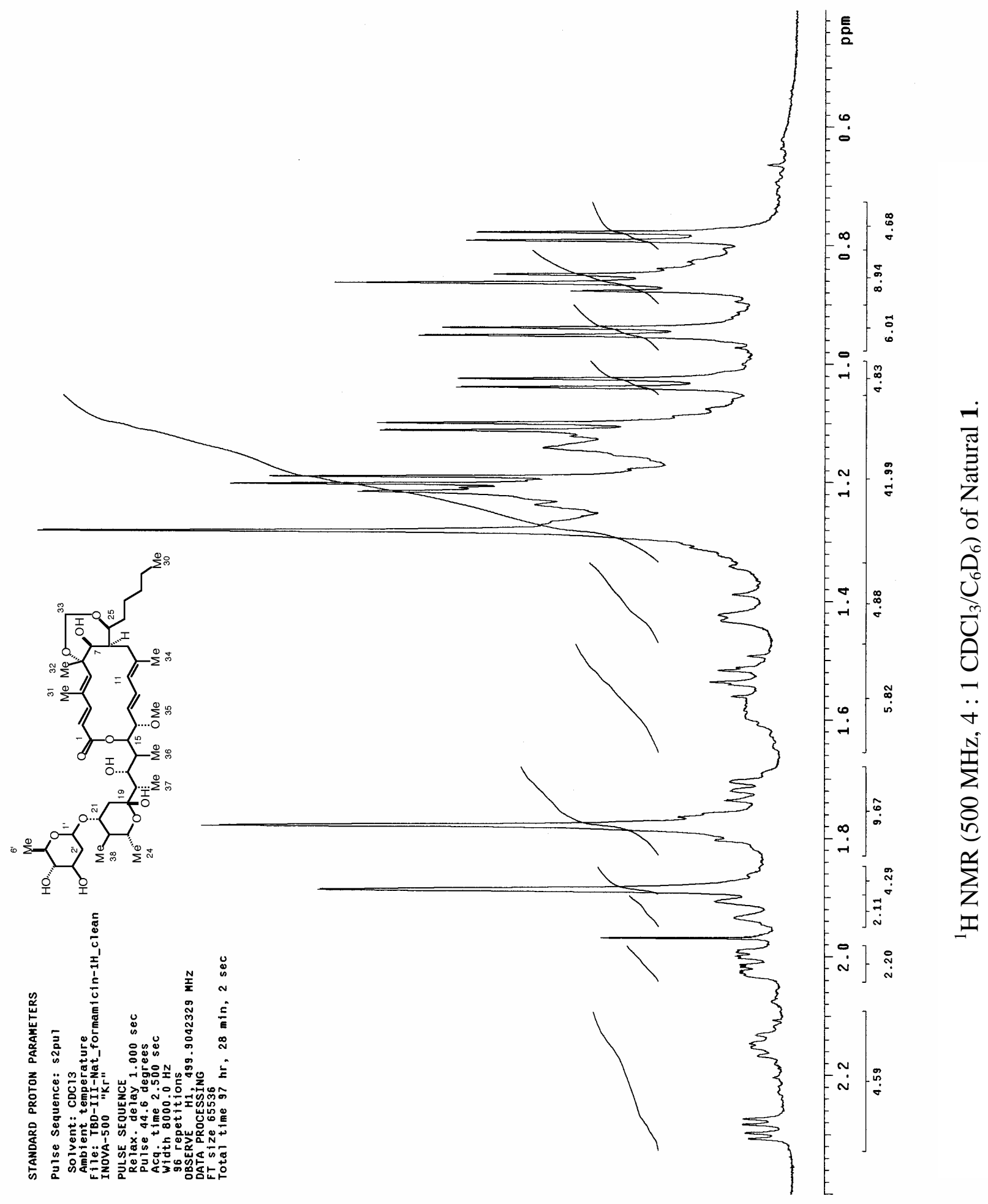



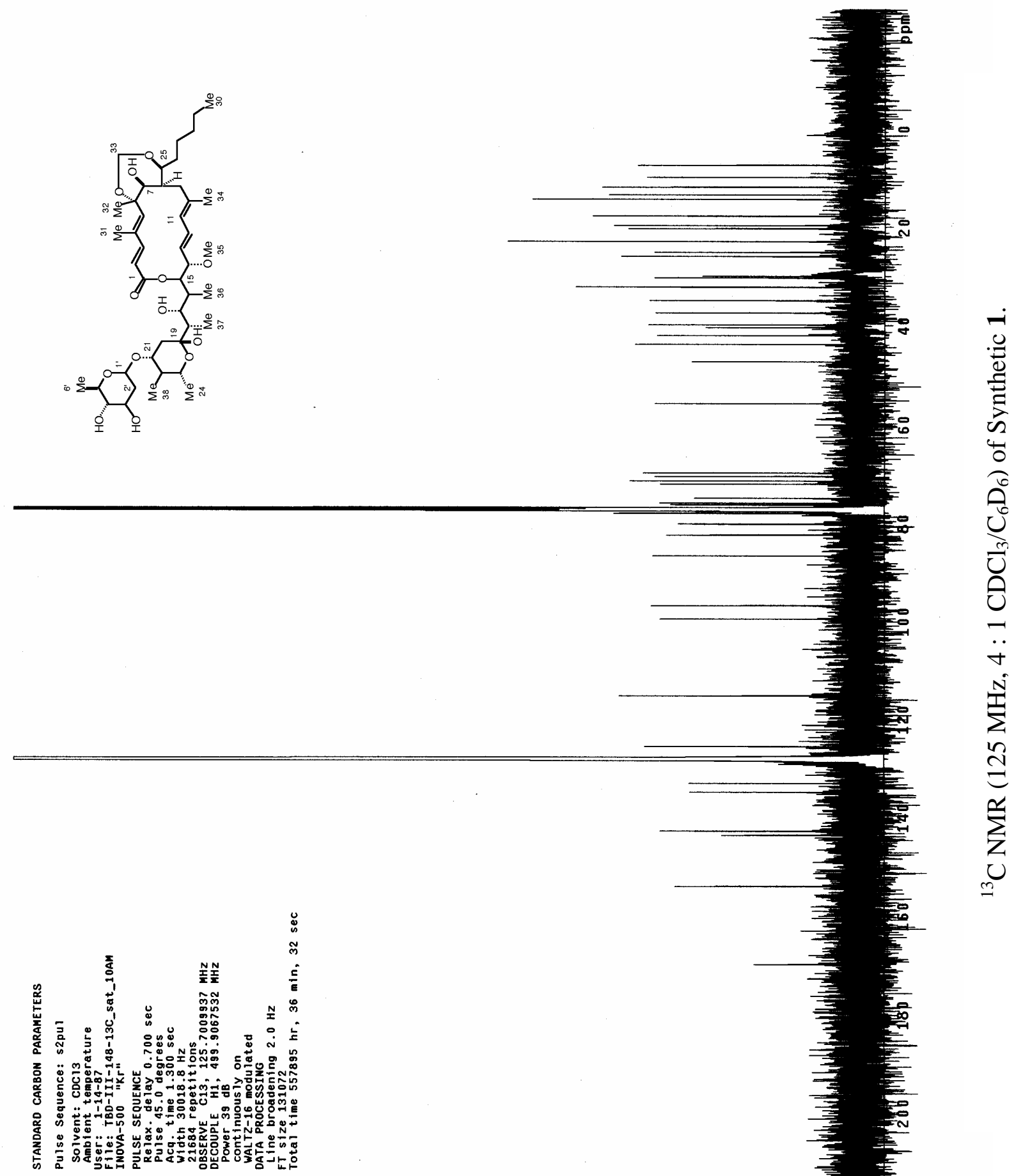


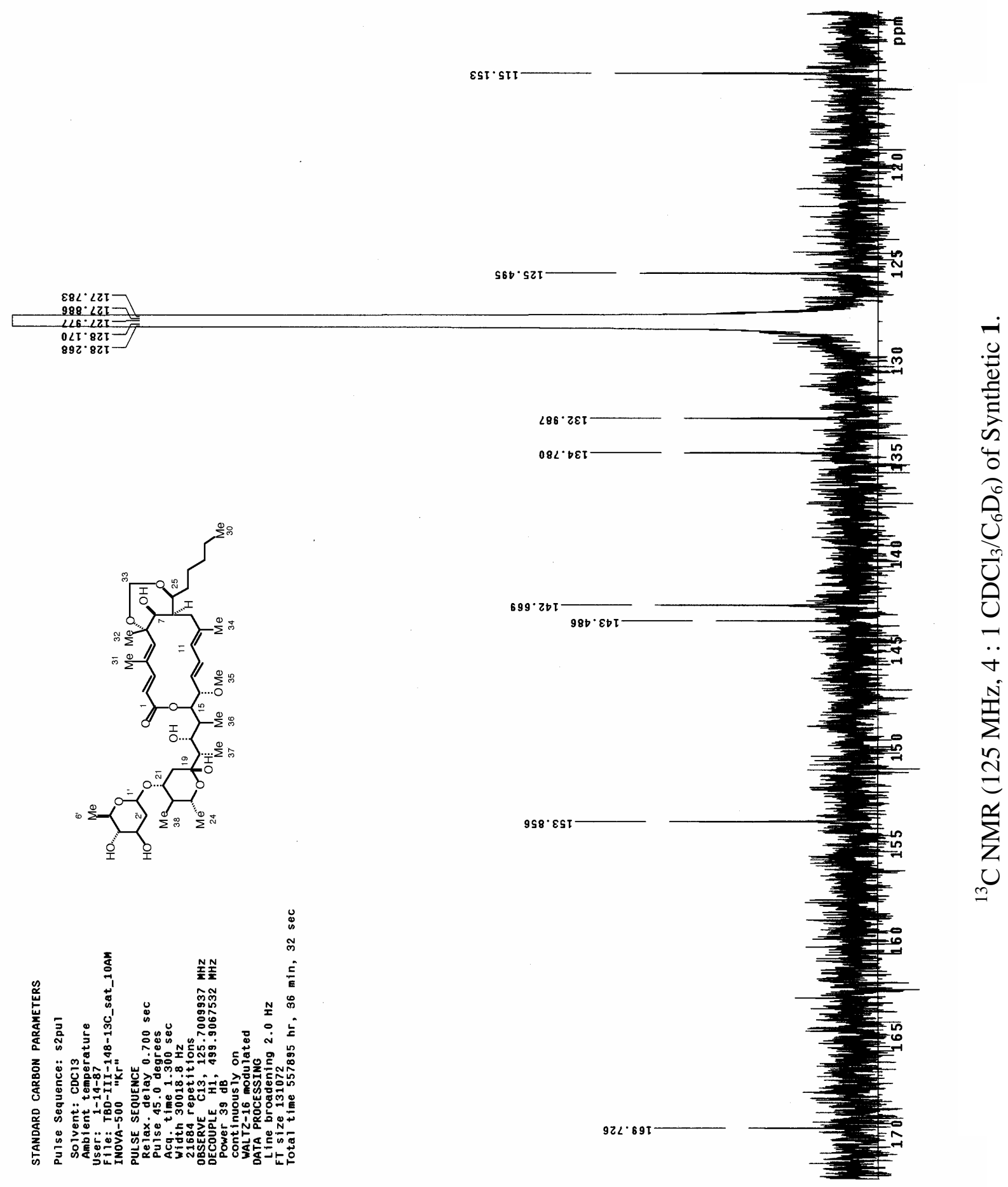




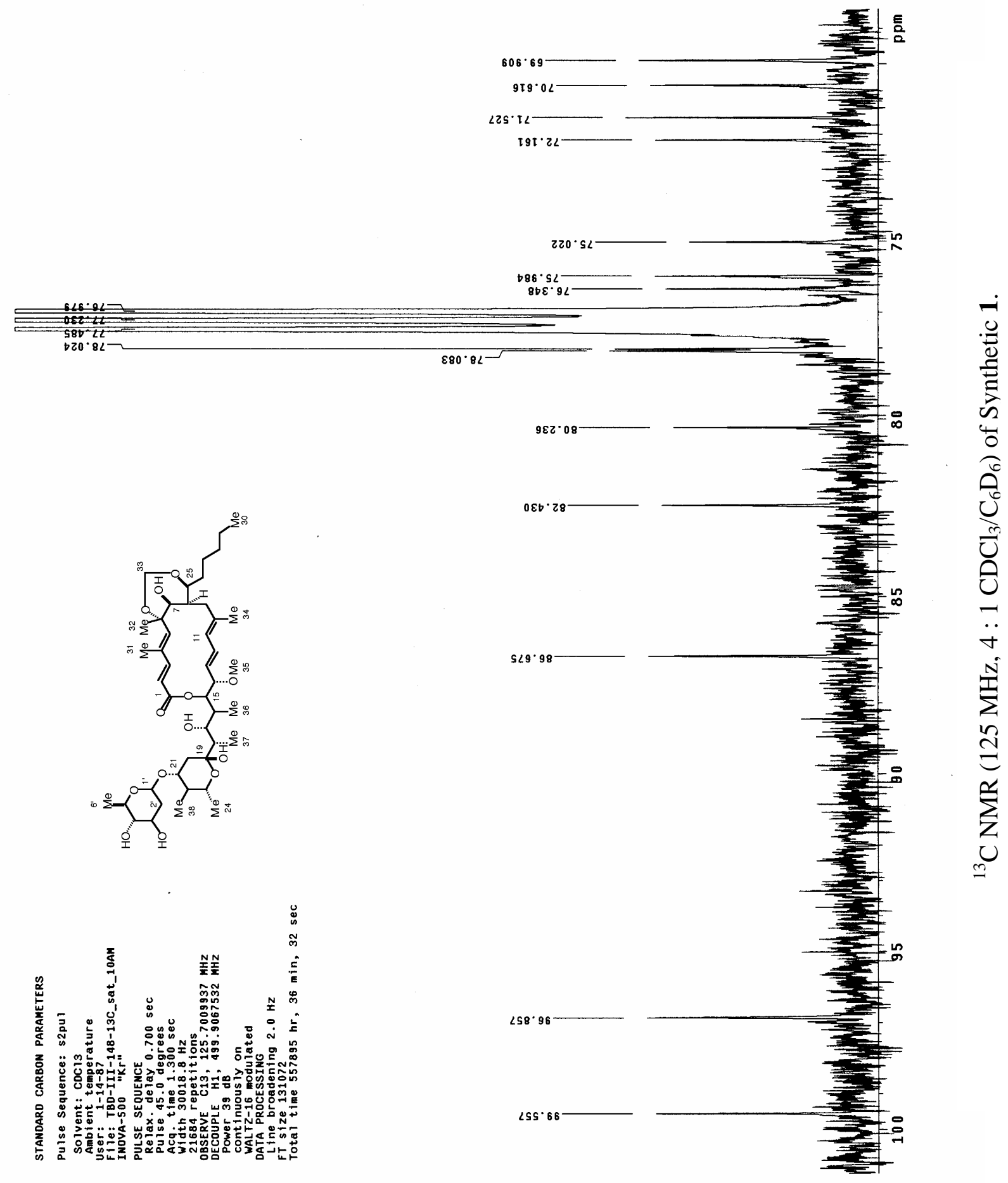



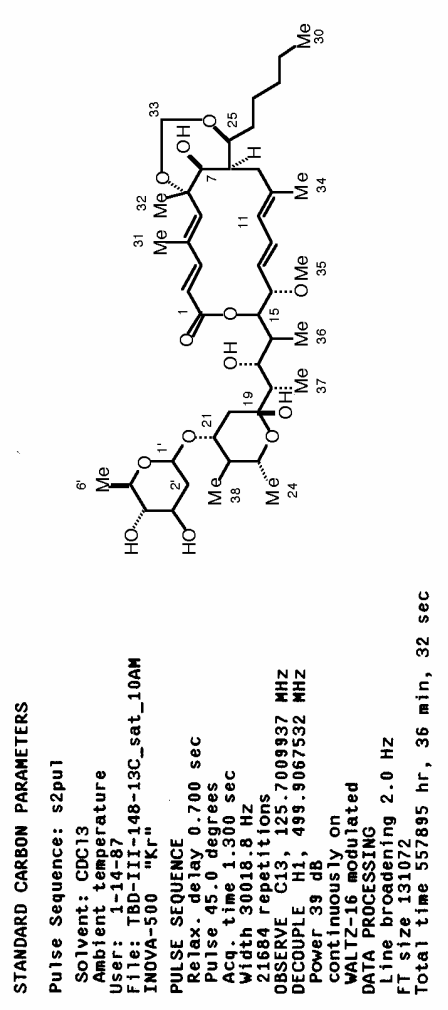

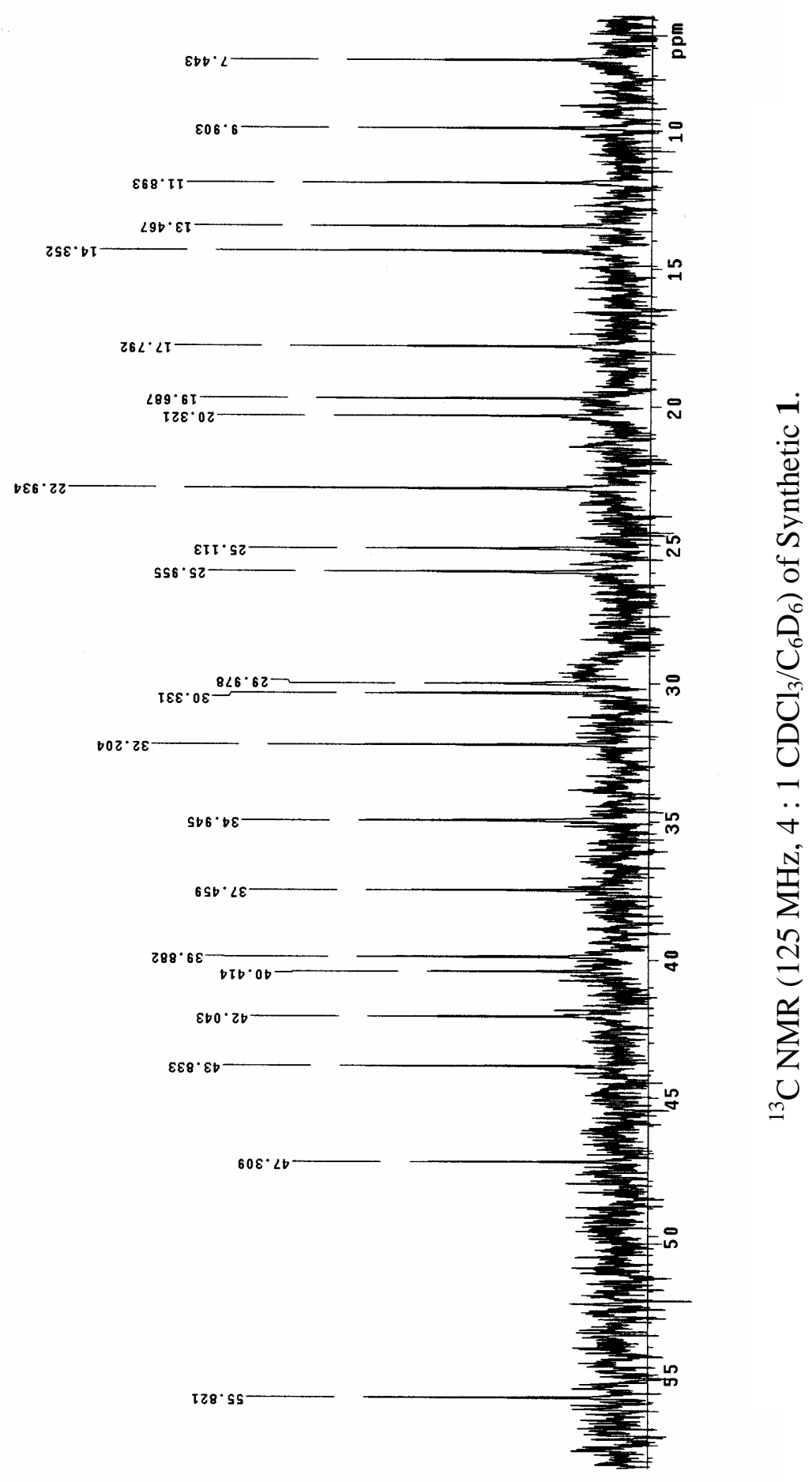

SI- $\quad 78$ 